Portland State University

PDXScholar

$1-1-2010$

\title{
Exploring Prehistoric Salmon Subsistence in the Willamette Valley using Zooarchaeological Records and Optimal Foraging Theory
}

J. Tait Elder

Portland State University

Follow this and additional works at: https://pdxscholar.library.pdx.edu/open_access_etds Let us know how access to this document benefits you.

Recommended Citation

Elder, J. Tait, "Exploring Prehistoric Salmon Subsistence in the Willamette Valley using Zooarchaeological Records and Optimal Foraging Theory" (2010). Dissertations and Theses. Paper 22.

https://doi.org/10.15760/etd.22

This Thesis is brought to you for free and open access. It has been accepted for inclusion in Dissertations and Theses by an authorized administrator of PDXScholar. Please contact us if we can make this document more accessible: pdxscholar@pdx.edu. 
Exploring Prehistoric Salmon Subsistence in the Willamette Valley using Zooarchaeological Records and Optimal Foraging Theory

by

J. Tait Elder

A thesis submitted in partial fulfillment of the requirements for the degree of

\author{
Master of Arts \\ in \\ Anthropology
}

Thesis Committee:

Virginia L. Butler, Chair

Kenneth M. Ames

Douglas Wilson

Portland State University

(C)2010 


\begin{abstract}
My research examines the prehistoric subsistence of native peoples of the Willamette Valley, Oregon through an analysis of the regional zooarchaeological records, and then modeling regional diet breadth. Through this analysis, I challenge commonly held stereotypes that the indigenous people of the Willamette Valley were strictly root eaters, and the basis for this claim, that salmon were not part of Native subsistence. The results of my research indicate that given the incomplete nature of the ethnohistoric record, very little can be said about expected cultural behaviors, such as salmon consumption, that appear to be absent in the Willamette Valley. In addition, since the faunal assemblage is so small in the Willamette Valley, zooarchaeological data are simply inadequate for studying the relationship between prehistoric peoples and their animal resources. Finally, optimal foraging modeling suggests that salmon is one of the higher ranked resources available to the Native People of the Willamette Valley.
\end{abstract}




\section{Acknowledgements}

Any progress that l've made as a student, writer, and person since my enrollment at Portland State University was not accomplished in isolation. I've been very fortunate to have the support and guidance of family, friends, cohorts, and instructors throughout my education. I'd like to thank the employees at the Oregon State Historic Preservation Office for assisting me in compiling all of the site reports within the Willamette Basin. Thanks to Dr. Douglas Wilson, a member of my thesis committee, for his comments and insight on my thesis and thesis defense. Thanks to Dr. Kenneth Ames for his patience, comments, and insight throughout my graduate education. Dr. Virginia Butler, thank you for inviting me to the party in the first place, your guidance and enthusiasm has always been appreciated. You've taught me to fish, and I plan to do it the rest of my life. I couldn't have asked for better lab mates than the ones I had in Alex Stevenson and Danny Gilmour. Thanks for the conversations and the camaraderie. Thank you, Linda O'keefe, for giving me a home away from home, and wonderful company over the past two years. Thank you for making all of this possible, and your patience, Beth. 
Table of Contents

Abstract

Acknowledgements ii

List of Figures vi

List of Tables vii

Chapter 1. Introduction 1

Chapter 2: Background 4

Willamette Valley Physiography

Salmon above Willamette Falls

Ethnohistoric Record of Subsistence in The Willamette Valley

Criticisms of the Direct Historical Approach

Overview of Willamette Valley Archaeology

Factors that Affect Faunal Representation in the Archaeological Record 20

Excavated Volume

23

Mesh Size

23

Location and Site Distributions

24

Preservation

26

Summary

Chapter 3: Compilation and Synthesis of Archaeological Records above

Willamette Falls

Report Collection Methods

Results

Records Compilation

Mid-Willamette Valley

North Santiam

36

South Santiam

McKenzie

Coast Fork

Middle Fork

38

Molalla

38

Tualatin

Yamhill

Upper Willamette

Summary of Willamette Valley Faunal Assemblages

Trends in Sub-Basin Data 
Chapter 4: Using the Diet Breadth Model from Optimal Foraging Theory to Examine Salmonid use in the Willamette Valley $\quad 54$

Human Behavioral Ecology $\quad 55$

Methods and Materials $\quad 58$

Results $\quad 64$

$\begin{array}{ll}\text { Discussion } & 68\end{array}$

Chapter 5. Discussion and Conclusions $\quad 70$

Diet Breadth $\quad 71$

$\begin{array}{ll}\text { Conclusion } & 75\end{array}$

$\begin{array}{ll}\text { References } & 77\end{array}$

Appendix A. Summary of all Cultural Resource Reports with Excavation within Willamette Valley, as of June $2009 \quad 87$

Appendix B. Summary Table of Resource Return Rates in the Willamette

Valley

$\begin{array}{ll}\text { Appendix C. Hazelnut OFM Calculations } & 121\end{array}$

Appendix D. Chinook Salmon Return Rates at Willamette Falls 122

Appendix E. Chinook Salmon Return Rates Above the Falls 123

Appendix F. Summary of Report References by Sub-Basin 124 


\section{List of Figures}

Figure 1. The Willamette Valley Watershed .............................................. 5

Figure 2. Location of Willamette Valley Sub-Basins ..................................... 30

Figure 3. Relationship Between Number of Sites with Faunal Remains and Total Number of Sites by Sub-Basin 48

Figure 4. Relationship Between Number of Sites with Faunal Remains and Number of Sites that list Volume and Mesh Size ... 
List of Tables

Table 1. Willamette Valley Archaeological Sites Summary Table 35

Table 2. Summary of Identified Faunal Remains in Willamette Valley Archaeological Sites 41

Table 3. Distance of Sites with Faunal Remains from a River 46

Table 4. Number of Excavated Sites vs. Number of Sites within Sub-basin with Faunal Remains 48

Table 5. Willamette Valley Resources Considered for Optimal Foraging Model,

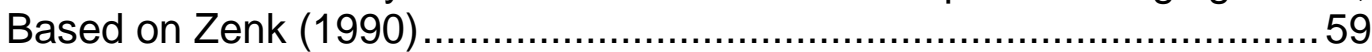

Table 6. Willamette Valley Resource Availability in Bi-Monthly Segments ..... 65

Table 7. Types and Post-Processing Return Rate of Resources near Willamette Falls, Averaged for Whole Year.... 66

Table 8. Resource Rank in Bi-Monthly Segments at or near Willamette Falls 66

Table 9. Types and Post-Processing Return Rate of Resources above Willamette Falls

Table 10. Resource Rank in Bi-Monthly Segments above Willamette Falls ... 68 
Chapter 1. Introduction

My research examines the prehistoric subsistence of native peoples of the Willamette Valley, Oregon through an analysis of the regional zooarchaeological records, and then modeling regional diet breadth. I intend to assess whether there is evidence for salmon consumption using the Willamette Valley archaeological record, and whether salmon (Oncorhynchus spp.) would have been a viable resource for exploitation.

Regional anthropological and archaeological literature tends to characterize the people of the Willamette region as "root eaters" or people that depended primarily on plant resources for subsistence. This belief is based on ethnohistoric and archaeological evidence of extensive plant exploitation in the valley (Coues 1897, Aikens 1993), and is further supported by sparse ethnohistoric evidence highlighting salmon use and the apparent absence of salmon remains in the archaeological record (Zenk 1990, Aikens 1993). It is also possible that archaeological overviews and ethnographic accounts of regional subsistence have been colored by the misconception that salmon could not ascend Willamette Falls (McKinney 1984:23). For example, in an archaeological overview, Beckham et al. (1986: 2) states that "no salmon spawned up the stream in the Upper Willamette". If true, this apparent exclusive reliance on plant foods would differ greatly from the commonly noted subsistence practices of the larger Pacific Northwest region, where 
anthropologists have viewed salmon as central to Native American diet (Schalk 1986:2).

However, there has been no systematic analysis of the zooarchaeological record from the Willamette Valley to substantiate the view that salmon was not exploited. To address this issue, I systematically overview and synthesize existing zooarchaeological records in the Willamette drainage to better understand the role or lack of role that salmon played in the subsistence practices of native peoples in the Willamette Valley. In doing this, I will ascertain whether the regional archaeological record is adequate for assessing salmon use in the Willamette drainage. If the regional archaeological record is adequate for analysis, then I will examine the extent to which people of this region exploited salmon. If the archaeological record supports the view that salmon were not exploited in the Willamette Valley, then this raises questions about why this resource was not used. For example, were salmon runs too unpredictable, did the timing of the appearance of this resource coincide with a more favored resource, and/or were salmon only able to ascend the falls in the very recent past? To address questions such as these, I will use the diet breadth model to test whether salmon exploitation would have been a viable option for the people of the Willamette Valley given the availability of a variety of resources. If the diet breadth analysis predicts that salmon should have been exploited, I will analyze whether other factors, 
such as an abundance of higher ranked resources, lowers the relative rank of salmon.

This thesis is organized into five chapters. Chapter 2 provides background on various components, including salmon abundance, and distribution above Willamette Falls, the regional ethnographic record, the existing archaeological record, and factors that affect faunal representation in the archaeological record. Chapter 3 presents the methods and results from analysis of the faunal records in the Willamette Valley. In chapter 4, I use diet breadth analysis to determine whether salmon should have been used by native peoples of the Willamette Valley, as well as analyze whether there were mitigating factors that affected the relative rank of salmon. Finally, chapter 5 summarize conclusions derived from the results and discuss the broader implications of my study. 
Chapter 2: Background

Willamette Valley Physiography

The Willamette Valley is a broad, north-south oriented drainage, located between the Coast Range to the west, and the Cascade Range to the east (Figure 1). The volcanic Cascade Range consists of uplifted Columbia River basalts, deposited in the Miocene. The Coast Range was formed through the development of volcanic islands at a eugeosyncline west of the ancestral Cascade Range (Glenn 1965). The valley extends 125 miles south to north, and is between 20 and 30 miles wide, east to west. Broad alluvial flats, low hills, and a very gentle north-facing slope characterize the valley floor (Franklin and Dyrness 1979:15). As a result of this very gentle slope, the river is slow, and has many meanders. The valley floor consists of deep (as much as 500 m) lacustrine and fluvial fill with between 10 and $50 \mathrm{~m}$ of quaternary sands and gravels at the surface (O'Connor et al. 2001), while the valley borders consist of various sedimentary and igneous rocks (Franklin and Dyrness 1979:15).

The northern end of the Willamette Valley has a single large, horseshoe shaped, block waterfall, which incises a gorge through tertiary basalt between Oregon City and West Linn (Figure 1). This falls, known as Willamette Falls, is approximately 12 m tall (Alt and Hyndman 1981, Wallick et al 2007), though given major developments over the last 150 years, it is difficult to know the pre-development configuration. The actual distance between the surface of the 
river above and below the falls varies depending on river flow rate and tidal force

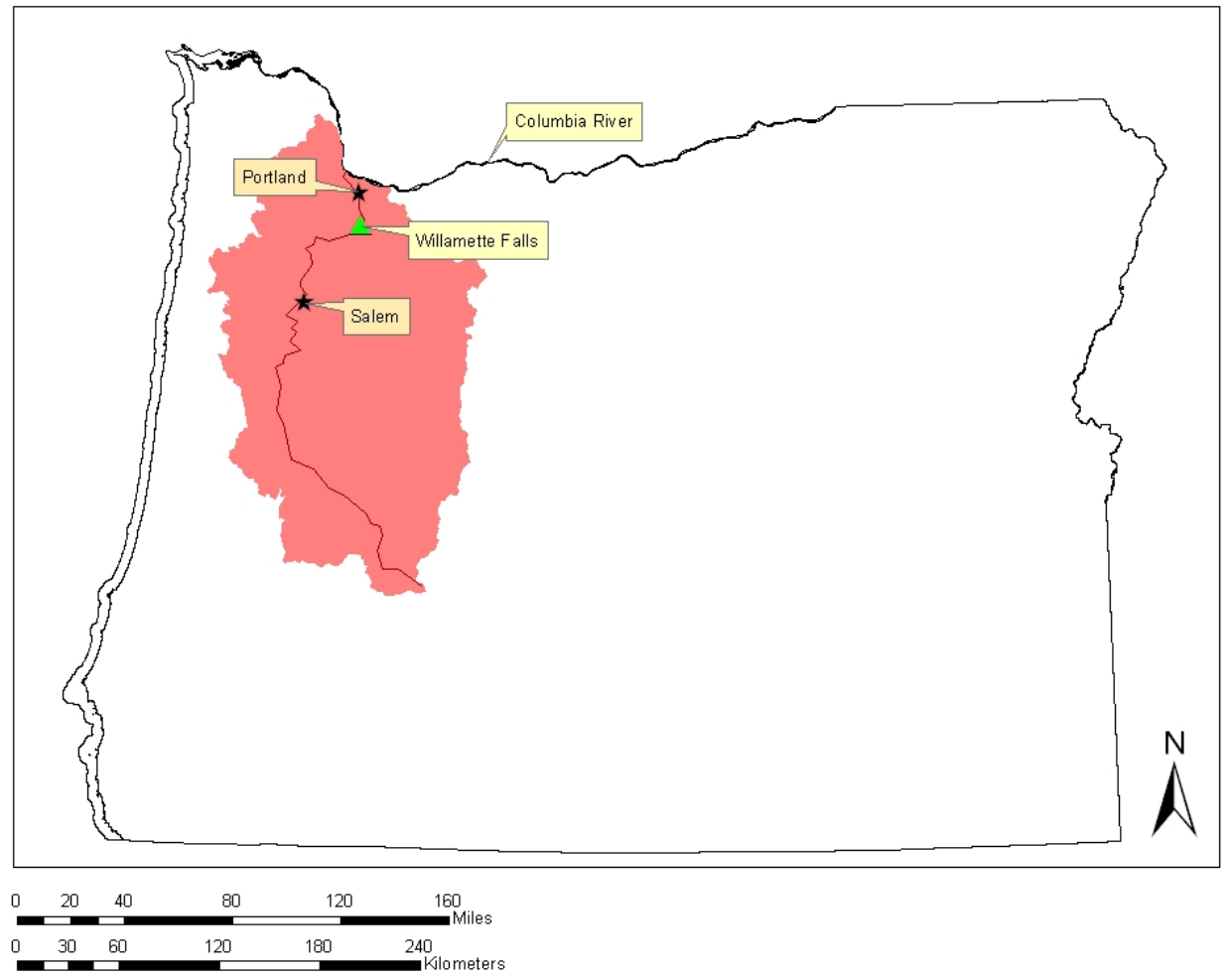

Figure 1. The Willamette Valley Watershed 
Three rivers, including the Coast Fork, Middle Fork and North Fork Willamette, which originate in the mountains south of Eugene, make up the headwaters of the Willamette River. There are nine main tributaries of the Willamette River. The McKenzie, Calapooia, North and South Santiam, Molalla, and Clackamas rivers have their headwaters in the Cascade Mountains, while the Long Tom, Marys, Luckiamute, Yamhill, and Tualatin rivers have their headwaters in the Coast Range mountains.

The vegetation communities located in the Willamette Valley include Oak (Quercus) woodlands, coniferous forests, and grasslands, the distribution of which has been affected by human activities (Franklin and Dyrness 1979: 110). The region is warmer and drier than any other region west of the Cascades in Oregon, primarily a result of the rain shadow of the Coast Range to the west. In addition, precipitation generally decreases as one moves east from the Coast Range towards the Cascades. Precipitation decreases slightly as one moves north from the headwaters of the Willamette to it's mouth. For example, Salem, OR., in the northern portion of the Willamette Valley gets around $1050 \mathrm{~mm}$ (41 inches) of rain per year, while Cottage Grove, OR., located at the southern portion of the Willamette Valley, gets around $1168 \mathrm{~mm}$ (46 inches) of rain per year. Mean annual temperature slightly increases as one moves south from the mouth of the Willamette River to its headwaters (51 
degrees F in Salem, OR. 52 degrees in Medford, OR.) (Franklin and Dyrness

1979: 110-111).

Salmon above Willamette Falls

The geomorphology of the Willamette River system has been used to argue that migrating salmon were blocked by Willamette Falls. Cheatham (1988:199) writes:

The lava flow that underlies the Willamette River near Oregon City stands in a special relationship to prehistoric cultural development in the Upper Willamette valley, for the Waterfall it created there presented an almost insurmountable barrier to anadromous fish attempting to migrate upstream. The result was that salmon constituted at best an undependable subsistence resource for the prehistoric peoples who lived upriver. The lava sill also prevented the river from increasing its slope, resulting in the maintenance of a broad, moist valley flood plain in the Upper Willamette Valley, an ideal setting for abundant propagation of the camas lily. In effect, the falls denied Willamette Valley Natives the use of salmon, a major subsistence resource throughout the Northwest Coast and Plateau, while significantly increasing the availability of camas, a secondary staple elsewhere.

The example above attempts to explain, through conjecture based upon regional geomorphology, why salmon were not used by the Native people of the Willamette Valley. However, this explanation does not adequately account for two realities. The first is that both biological (Fulton 1968, 1970, Quinn 2005: 323) and ethnohistorical evidence (see below) show that Willamette Falls did not form a permanent impassible barrier to fish migration. Fulton (1968:4-7; 1970: 5) notes, based on a regional fish inventory, that 
anadromous salmonids, including steelhead trout (Oncorhynchus mykiss) and Chinook salmon (Oncorhynchus tshawytscha) spawn in the upper Willamette River and its tributaries while coho salmon (Oncorhynchus kisutch) were introduced historically (Fulton 1970: 15-17). The second, which I will address through my research, is that zooarchaeological records have not been sufficiently examined to substantiate the claim that salmon were not used by the Native people of the Willamette Valley.

Several factors, including geomorphology and climate patterns, may have limited salmon passage historically and in the more ancient past. Schalk (1986:13) suggests that seasonal variations in river height and waterfall volume affected the vertical distance that the fish need to jump to ascend the falls. During periods where a high volume of water is expelled over the waterfall and the river is high (after spring snow melt and in early summer), the vertical distance may be half that of the falls during the dry season, which extends between July and October (Zenk 1976). As a result, fish may only have been able to ascend the falls in the spring and summer. This also suggests that in years with decreased precipitation or limited snow-pack, salmon may have been unable to ascend the falls at all.

It is also possible that the falls may not have been passable to salmon during the early-mid Holocene because of lower sea levels. During the past 12,000 years, sea level rose nearly 110 m (Peterson and Phipps 1992, USGS 2008). Sea level began stabilizing at around 3000 years BP, rising less than 5 
$\mathrm{m}$ from this time to the present (Peterson and Phipps 1992). Additionally, early rapid accumulation of sediment in the Columbia Basin, prompted by abruptly rising sea levels (Peterson and Phipps 1992) further increased river elevation over time. Therefore, a passable falls may have been a consequence of sediment in-filling associated with glacial melt and rising sea levels during the early Holocene. Therefore, fish passage above Willamette Falls may only have been possible within the last 3000 years, around the time when sea levels stabilized.

In addition to temporal constraints on fish passage and distribution provided by Willamette Falls, the origin of the tributaries of the Willamette River above Willamette Falls affects salmon spatial distribution. Galbreath (1965) notes that "the spring Chinook salmon ran only in the larger tributaries heading in[to] the Cascades..." which includes the North and South Santiam, McKenzie, and Middle Fork tributaries. In addition, Galbreath's (1965) analysis of the timing of fish runs in the lower Columbia River region notes small salmon runs in the Molalla, Pudding, and Calapooya Rivers of the Coast Range, but no runs in the Tualatin, Yamhill, Luckiamute, Marys, and Long Tom Rivers. Zenk (1976:73-74) speculates that the distribution of fish runs observed by Galbreath $(1965)$ and Fulton $(1968,1970)$ reflect that the most favorable conditions for salmon spawning occur in relatively large streams with high altitude headwaters, which tend to occur in the Cascade Range mountain on the valley's east side. 
Ethnohistoric Record of Subsistence in The Willamette Valley

The archaeological interpretation of the subsistence practices and culture of Willamette Valley Native people is heavily informed by historical accounts and ethnographic records from the region. In the early $19^{\text {th }}$ Century when Euro-Americans were beginning to enter the valley, the Willamette Valley was occupied by approximately 13 "tribes" of people, collectively known as Kalapuyans, for their shared linguistic and cultural traits (Zenk 1990). In 1814, Alexander Henry (Coues 1897:814) reported that plant resources, and specifically roots constituted the bulk of the Kalapuyan diet. This account, combined with reports that salmon simply could not travel above Willamette Falls (Ross 1859, Coues 1897), supports the view that salmon were not a part of indigenous subsistence strategies.

However, other ethnohistoric accounts dating thirty years later suggest that salmon were not only able to ascend the falls, but that Native groups were actively harvesting these fish (Wilkes 1845:344-345). Wilkes (1845:344) writes that:

The salmon leap the falls; and it would be inconceivable, if not actually witnessed, how they can force themselves up and after a leap of from ten to twelve feet retain enough strength to stem the force of the water above. 
Additionally, the Hudson's Bay Company set up a trading area at the falls, purchasing 800 barrels of salmon in 1841 from Native groups in the area (Craig and Hacker 1940).

The contrasting perspectives regarding both $19^{\text {th }}$ century observations of regional subsistence practices, as well as whether salmon could ascend Willamette Falls highlights the importance of understanding context from which the ethnohistoric record was drawn. There are few early ethnohistoric accounts from the Willamette Valley (Zenk 2008). The scarcity of ethnohistoric records documenting the use of salmon above Willamette Falls may simply be due to the limited writings from the region overall, or a lack of writings at the appropriate time, or whether the observations were in the appropriate location to observe salmon exploitation. Adding to this complexity, large-scale epidemics in 1782-1783 and 1830-1833 (McKinney 1984:31, Zenk 1990:551) caused massive decline in the Native American population in the Willamette Valley from nearly 32,000 people prior to 1830 to just over 2,100 people after the mid 1830s, resulting in the total abandonment of many villages (Boyd 1975: 135-136). This event was followed closely by the removal of the Kalapuyan people from the Willamette Valley at the end of the 1850s (Spores 1993:171). The catastrophic population decline and dispersal of the Kalapuyan people almost certainly resulted in the loss of cultural practices. Spores (1993:172) notes that: 
Even before the arrival of the Lewis and Clark expedition in $1803^{1}$, trade goods and diseases brought by white men had begun to alter Native Life in the Willamette Valley. Although whites were trickling into the valley during the 1830s, it was not until the 1840s that farmers, traders and missionaries settled the area in appreciable numbers, and by this time the Native population had already been drastically reduced.

The opportunity for Euro-Americans to observe Indian fishing practices was further diminished by the timing and location of early Euro-American settlements. Bunting (1995:418) notes that fewer than a dozen farms had been established in the Willamette Valley prior to 1850, with just a few more attempted by the 1880s. Additionally, Euro-Americans that immigrated to the region tended to avoid floodplains, and instead chose to inhabit upland, grassland, and near-timberline areas. Around $90 \%$ of the farms established in the Willamette Valley were located in these areas in the 1850s (Bunting 1995: 417).

Scholarly ethnographic research in the region began with A.S.

Gatschet's 1877 interviews with the Chinook and Kalapuya people of the Willamette Valley (Zenk 2008:9). Further early ethnographic research in the Willamette Valley included recording languages and place names. However, Zenk (2008:8) notes that:

A handful of Native elders born into the era of Euro-American frontier expansion, which saw the virtual obsolescence of all Northwest Oregon indigenous languages and lifeways, are responsible for most of what we know about these languages.

\footnotetext{
${ }^{1}$ Note: Lewis and Clark arrived in the Lower Columbia River area in the fall of 1805.
} 
From these records, anthropologists have tended to present Willamette Valley native peoples as an exception to the rule that the Native people of the Pacific Northwest relied on salmon. It is on this basis that the Northwest Power Planning Council concluded that the ethnographic literature from the Willamette region is not likely to add much to our understanding of the past distribution and abundance of salmon populations (1986:36).

Interestingly, a single scholarly ethnographic researcher, working in the late 1920's and early 1930's, discussed salmon exploitation above Willamette Falls. From oral traditions of elders, Jacobs (1945) noted that the Kalapuya of the Santiam River fished for salmon, steelhead, trout, and eels (local common name for lamprey Lampetra spp.). Trout were caught using line and lures, while salmon and steelhead were captured using spears.

\section{Criticisms of the Direct Historical Approach}

The common view that indigenous peoples of the Willamette region did not consume salmon is likely derived from two assumptions: (1) The ethnohistorical record yields a mostly unmodified view of the behavior of prehistoric people, and (2) The regional archaeological record is a representative sample of subsistence behavior. The first point will be explored in the following discussion, while the second will be explored later in this thesis. 
Much of what we know about the subsistence practices of the prehistoric Kalapuyan people comes from application of the direct historical approach. This approach uses historical or ethnographic information about existing cultures to interpret archaeological data from an earlier time period (Stewart 1942, Trigger 1996: 510). It is generally applied in order to identify ethnographic affiliation, construct chronologies, and to gain insight into the human behavior that may have produced the archaeological record (Lyman and O'Brien 2001:310). Based on the above mentioned ethnographic sources suggesting local reliance on plant food, application of the direct historical approach would lead one to conclude salmon were not utilized in this area. This conclusion is questionable, however. While the direct historical approach can yield important connections between past and present behavior, it has limitations.

The divide between ethnographically recorded culture systems and the pre-contact past potentially limits interpretation of what was and was not done in the past. Dunnell (1989) argues that the catastrophic decline of North American Native American populations affected cultural continuity between ethnographically recorded cultures and pre-contact cultures. For example, Dunnell (1989:565) points to "the [Euro-American] notion that since Indians were not known to build mounds historically they did not do so in the past." Catastrophic population decline represents a reduction in the total range of variability, known as the Founder Effect (Dunnell 1989:570). In the context of 
North American native populations, post-depopulation cultural systems represent a fraction of the total range of cultural behaviors exhibited during pre-contact times. This effect is further exacerbated by the demographic shift associated with epidemic diseases, where the very young and old are disproportionately killed (Trigger 1966:439-440). Furthermore, Schalk (1986) notes that not only had Native cultures been significantly affected by disease prior to Euro-American contact, but also by the introduction of the horse, which increased the mobility and range of many Native groups.

In addition, methods used by early ethnographers probably contributed to the loss of knowledge about the $19^{\text {th }}$ century. For example, early ethnographers aggregated culture groups into "tribes" by linguistic criteria rather than by individual bands or groups that either lived or subsisted together. Schalk (1986:4) suggests that this is an issue because "the patterns of food resource use from one band to the next... were often highly variable." Schalk (1986:4) notes too, that "...most ethnographic studies tend to focus on typical patterns of behavior rather than the range of variation."

Finally, there are complications regarding the temporal and spatial resolution of data collected from informants. Wobst (1978:305) notes that informants observe behavior closest to their location. When distance from that location increases, the informants detailed knowledge of cultural behavior decreases. This relationship is also an issue when considering time depth. Lyman and O'Brien (2001: 317) note that ethnographic analogy, key to the 
direct historical approach, "works progressively less well as the subject archaeological manifestation increases in age."

In sum, there are a series of issues to consider when using ethnographic data to inform interpretations of behavior in the archaeological record. For example, one must consider whether there is potential for discontinuity affecting the variety of behaviors expressed, either through epidemic disease or migration prior to the collection of ethnographic data, as well as when this discontinuity took place. Additionally, one must consider the observer and/or informant's relationship, both spatially and temporally, with either the behavior or event that is being researched. Finally, one must consider how the ethnographer groups cultures, and the types of generalizations drawn from this aggregation.

It is unclear how much rapid population decline and displacement affected representation of the range of Native cultural behaviors in the region. Nor is it likely, based on their settlement patterns, that Euro-Americans in the Willamette Valley were present at the right location, or at the right time to observe Native subsistence practices that would have included salmon exploitation. Furthermore, most traits characteristic of cultural practices for the entire Willamette Valley were drawn from knowledge of only two groups who lived in the northern end of the valley, with streams of limited salmon runs during historic times. It is unlikely that the same pattern of subsistence was ubiquitous throughout the valley, especially considering that neither the 
Yamhill nor the Tualatin drainage is known to have large salmon runs relative to other sub-drainages south of Willamette Falls (Zenk 1976). Since the Willamette Valley ethnographic record is particularly fragmented and incomplete, one cannot reasonably argue that it represents (1) unmodified cultural practices or (2) the full range of cultural behaviors of the $19^{\text {th }}$ century, much less centuries before. Therefore, it is best suited for describing behaviors that were observed rather than ruling out expected behaviors that were not. Only through analysis of the archaeological record can these expected behaviors, such as salmon exploitation, be tested.

Overview of Willamette Valley Archaeology

In the Pacific Northwest and the Plateau, salmon and steelhead were considered favored foods by indigenous peoples (Schalk 1986, Ames 1994, Matson and Coupland 1995, Ames and Maschner 1999). The exploitation of salmon as a food source has a long history in the Pacific Northwest dating back as far as 9000-10,000 years before present (Cressman et al. 1960, Butler and O'Connor 2004), and the exploitation and storage of salmon is considered to be one of the primary factors in the development of semisedentary hunter-gatherer society in the Pacific Northwest (Schalk 1981, Matson 1992, Ames 1994:211). However, there is debate as to whether increased use of salmon led to the emergence of complex societies (Butler and Campbell 2004:389), with the rationale that if salmon were important to the development of sedentism, then use of this resource would intensify as 
this practice developed. Nevertheless, salmon represent a ubiquitous and consistently utilized resource in the Pacific Northwest.

Willamette Valley archaeological overviews have highlighted finds that support the view that camas (Camassia quamash), as well as other plant resources, were exploited. For example, bank erosion at the Havannan Creek Site exposed multiple hearth/roasting pit features, as well as nearly 350 charred camas bulbs, which were radiocarbon dated to between 7750 and 6830 BP (Aikens 1993), suggesting that the practice of camas exploitation has a long history. The Perkins Park, Upper Long Tom River, Kirk Park, Flanagan, Benjamin, Hurd, Hagar's Cove, and Fuller and Fanning Mound sites all have roasting features and charred bulbs, as well as other macrobotanical remains (Aikens 1993:193-212).

Previous general syntheses of Willamette Valley Archaeology suggest that faunal remains are relatively scarce. Highly fragmented mammal and bird bones were found at the Perkins Park Site; faunal remains were present at the Kirk Park, Cascadia Cave, and Rigdon's Horse Pasture Cave site, with deer representing the predominant taxa (Alkens 1993). Salmon remains were not mentioned in Aikens' (1993) Willamette Valley archaeological synthesis. Interestingly, of the five sites. Alkens mentions with any faunal remains, two are located in caves, which tend to have favorable preservation conditions. These observations are echoed by Lyman (1987: D.1), who notes that very few sites from areas south and west of the Willamette Valley contain 
zooarchaeological remains. Lyman further suggests that the high soil acidity in the Willamette Valley may explain the relative absence of faunal remains. Additionally, Thoms (1989:307) notes that fine screening and flotation were not used before the 1980s, thus sampling technique cannot be ruled out as a factor in faunal representation in the Willamette Valley. In summation, it is probable that factors such as preservation conditions and data collection methods are affecting the discovery of faunal remains in the Willamette Valley.

McKinney (1984: 28), in her review of Kalapuyan subsistence, notes that gear (eg. net weights, clubs) associated with fishing has been found above Willamette Falls on the Yamhill River. This suggests, at the very least, that some kind of fishing activity occurred above the falls; whether this gear was used to catch salmon or other fish is unknown. Additionally, Laughlin (1943) notes that fish vertebrae are present at the Fuller and Fanning mounds near the Yamhill River. These remains were not identified beyond "fish vertebrae." This evidence further bolsters the claim that some kind of fishing took place above Willamette Falls.

The prevalence of camas ovens above Willamette Falls, and the lack of discussion of salmon remains in regional archaeological overviews (White 1979:567, Pettigrew 1990) supports the view that plants were intensively used in the region, while salmon were not. However, it is unclear, in regional site overviews, if absence of faunal remains from the record is due to their true absence, archaeological recovery methods, omission of faunal data from site 
reports, or context of archaeological sampling (e.g. have sites been sampled adjacent to rivers where remains of fishing activities are most likely to be found?). Furthermore, heavy reliance on the direct historical approach by archaeologists has re-enforced the view that Native peoples were mainly plant eaters in the ancient past.

Factors that Affect Faunal Representation in the Archaeological Record The study of zooarchaeological remains can provide a record of human-animal relationships over time and space, which can then be used to create a record of specific animal distributions over varying temporal and spatial scales. However, this view must be qualified by an understanding of what presence, and more importantly, absence of animal classes in the zooarchaeological record means. Without this context, it is likely that patterns in faunal representation in the archaeological record may be a function of sample design or other factors, rather than the actual relationship between humans and animals.

When an expected artifact class is present, the implications are clear, the artifact in question was used, deposited, and preserved. Absence, however, is a complicated state that involves multiple possibilities, stemming from the human behavior that created cultural materials and in sampling design, which makes analysis difficult (e.g. Was the resource or artifact not used? Did it not preserve? Has there been enough archaeological research to know?). The ambiguity regarding whether Native people of the Willamette 
Valley exploited salmon provides a perfect opportunity to explore the importance of zooarchaeological analysis, as well as the complexities associated with the interpretation of presence and absence in the archaeological record.

The archaeological record is a product of human behavior, reflected in both the initial deposition and subsequent collection of cultural materials. Schiffer $(1983,1996)$ differentiates between cultural processes, those directly linked to the behavior that led to initial deposition, and environmental processes, which act on material culture after deposition. Initial human behavior (cultural processes) dictates the variety and distribution of cultural materials on the landscape (e.g. Binford 1980), while environmental processes may modify the pattern of these materials by selectively preserving specific classes of cultural materials (e.g. Stein 1992). Finally, archaeological sampling, including site excavation design, volume excavated, and mesh size (Schiffer 1996), further affects the variety and distribution of materials that are collected. In sum, we need to consider and evaluate the role of natural processes and sample design given the amount of research that highlights their effects on interpretations of original human behavior.

Artifact preservation, a natural process, is a factor that one must consider when trying to interpret patterning in archaeo-faunal distributions. Importantly, one cannot modify their research design to mitigate the effects of preservation conditions. Instead, post hoc knowledge of preservation 
conditions from a given region helps a researcher determine whether or not absence is a function of preservation.

It is important to recognize how research design characteristics allow for the detection of salmon elements. More generally, in order to determine whether the archaeological sample from a given region is adequate to assess archaeological questions that are quantitative in nature, or to discern cultural materials with specific constraints that affect visibility, one must identify which factors affect the abundance and distribution of the targeted class of items on the landscape. These factors include excavation methods, location of excavation, and volume excavated at sites (Schiffer 1996). Additionally, one must attempt to determine if methods, including sample location on the landscape, and volume excavated (Wolff 1974) allow for the discovery of items that are potentially rare. In order to do this, one must assess whether the item one is trying to perceive is simply rare, or rare and also found in selected places, or rare, found in selected places, and difficult to see (Lyman 1995: 371). Once the nature of the desired data is understood, one can modify their sample design to detect the class of item by increasing sample size, decreasing mesh size, and/or increasing the resolution with which one can predict the location of a given resource. Placing this discussion in the context of zooarchaeology, sample design modification should vary by size of taxa, intensity of exploitation, and location of exploitation. 
Here, I discuss the main attributes of sampling design that affect whether the archaeological record includes fish bones. Since I will be compiling and analyzing zooarchaeological records from the Willamette Valley, I will need to address how methodological factors affect salmon bone representation in the archaeological record, since these are the easiest to control for.

\section{Excavated Volume}

As the excavated volume increases, assemblages tend to increase in size and variety (Lyman 1995, Thomas 1989). As a result, with a relatively small sample size, a limited variety of activities will be represented, and the probability of finding rare items decreases. Unfortunately, there is no metric with which to assess whether the amount of material excavated in the region is adequate to register rare items, or specific taxa. However, there are multiple methods (species-area curve, bootstrapping, rarefaction) to determine whether the richness of any given artifact assemblage adequately reflects the richness of the underlying population (Cochrane 2003, Lyman and Ames 2007).

\section{Mesh Size}

The effect of mesh size on faunal representation is well-studied (Thomas 1969, Grayson 1984, Cannon 1999), as is the research regarding the effect of mesh size on fish faunal representation (Casteel 1972, Nagaoka 2005, Zohar and Belmaker 2005). Research by Butler (1993) even explores the effect of mesh size on differential recovery of salmonid elements. 
However, it is difficult to list a specific mesh size that is the point at which one starts recovering salmon remains. This is partially because of the variability in salmon body size among species and extent of fragmentation. The species that migrate through to the Willamette River system are relatively large bodied. Adult steelhead are between 5 and 10 pounds (2.5 to $4.5 \mathrm{~kg}$, Wydoski and Whtney 2003: 73-84). Adult coho salmon are similar in size, most weighing between 8 and 12 pounds (3.6 to $5.4 \mathrm{~kg}$, Wydoski and Whtney 2003: 73-84). Adult chinook salmon are larger than coho salmon and steelhead, at around 22 pounds ( $10 \mathrm{~kg}$, Wydoski and Whtney 2003: 73-84). Since most of the cranial and pectoral elements, as well as relatively complete vertebrae of adult salmon are recoverable in $1 / 4$ " mesh (Casteel 1972, Butler 1993), research designs that have the potential to recover salmon remains should minimally screen soil through $1 / 4$ " mesh. On the other hand, if remains are extremely fragmentary, smaller mesh sizes (1/8", 1/16") would be needed.

Location and Site Distributions Known site distributions represent a combination of original settlement patterns and land use activities and contemporary archaeological field practices. The original human behavior underlying land use affects both site distribution and the content of sites, and is independent of research design. Comparatively, a researcher's sampling design can greatly affect the probability of discovering sites linked with particular activities, such as fishing or long term use. 
Optimal foraging theory can be used to develop expectations, likelihoods, and obtain rationale for locations on the landscape that should be linked to fishing activities. Jones and Madsen (1989) suggest that for a given resource, there is a distance at which the caloric cost of transportation exceeds the caloric gain provided by the exploited resource. Transportation costs, which include resource weight, and distance between catch locations and central base, are logistical considerations when exploiting resources (Metcalfe and Barlow 1992). Therefore, the presence and abundance of salmon remains in archaeological sites should be inversely related to distance from the location where salmon would be collected. In other words, sites that yield salmon remains should be close to a water source where salmon are present. However, the issue of "how close" is not well studied. For this project, sites will be included if they fall within the Willamette drainage, as delineated by drainage polygons downloaded from the USGS National Hydrograpic Dataset website (http://nhd.usgs.gov/data.html).

The known distribution of sites may be representative of the population of archaeological sites in the region or it may only represent a limited variety of sites, as a function of the sample design used. Most of the known sites in the Willamette Valley were found in the course of Cultural Resource Management projects (CRM). While this is no different than most parts of the United States, it is important to recognize that site distributions are a product of both ancient 
human behavior but also sampling that was primarily driven by $20^{\text {th }}$ century development.

Preservation

A confounding factor that supercedes the consideration of mesh size, excavation location, and volume excavated is whether the object one is looking for preserves in the archaeological record. Some objects, such as stone tools, tend to preserve well, while preservation of faunal material, wood, and plant fiber varies depending on a range of factors, including condition of deposition, speed of burial, and depositional environment (e.g. soil P.H., sediment grain size). Faunal material, in particular, can be sensitive to the surrounding environment. Processing and digestion (Lubinski 1996: 175), faunal attributes such as bone density, size, shape (Butler and Chatter 1994), and porosity (Lubinski 1996: 175) all affect preservation of faunal materials. Additionally, different elements preserve differentially in archaeological sites. Flat, thin bones, such as cranial and fin elements, are usually the first to degrade over time, while denser bones, such as vertebrae, tend to degrade at a slower rate (Lubinski 1996: 179-180). Within the Willamette Valley, Lyman (1987: D.1) notes that very few sites from the southern portion of the valley contain zooarchaeological remains, and further suggests that the high soil acidity in the region may explain the relative absence of faunal remains. If true, then we would expect scarcity of faunal remains from all vertebrate classes across the region. On the other hand, if all vertebrate classes but salmon are 
represented in archaeological sites, then poor preservation could not be cited to account for the scarcity of salmon remains.

\section{Summary}

In the Pacific Northwest, salmon are viewed as central to the Native American diet, when available. Environmental and ethnohistorical evidence indicate that salmon were able to ascend Willamette Falls and were in the middle and upper reaches of the Willamette River. However, previous archaeological and ethnographic overviews of the region indicate that salmon were not used. Analysis of the composition of the ethnographic record, and the direct historical approach, reveals that there are limitations to using ethnographic information to rule out expected cultural behaviors. Finally, since the archaeological record represents a sample of human behavior filtered by post-depositional and methodological factors, it is necessary to determine whether patterns in the archaeological record represent original human behavior or differential recovery of artifacts. 
Chapter 3: Compilation and Synthesis of Archaeological Records above Willamette Falls

\section{Report Collection Methods}

To create the most comprehensive zooarchaeological record for the Willamette Valley possible, I used a variety of database searches at the Oregon State Historic Preservation Office (SHPO) in Salem, Oregon, including those encapsulated in ArcGIS, the SHPO's Geographic Information System. First, I generated a list of known sites located in the Willamette Valley, and it's tributary basins. To do this, I uploaded two-dimensional polygons into the SHPO GIS system, which represent the shape and location of the Willamette Valley and its tributary basins, including the Tualatin, Mollala-Pudding, Yamhill, North Santiam, South Santiam, McKinney, Mid-Fork Willamette, Coast Fork Willamette, Upper Willamette, and the Mid-Willamette (Figure 2). I excluded two sub-basins, which are downstream of Willamette Falls, since the main debate concerns salmon use upriver of the falls. The remaining ten subbasins became the organizing unit for my study, with all site records being compiled within each.

I made every effort to include all site excavation reports within the Willamette Valley as of June 2009. However, some reports may have been left out of analysis, due to factors such as site point location errors on the GIS database, report omissions from the library database, and human error. I learned in January 2010 about one site report that was not included (Fagan et 
al 1994). While there may be a few records missing from my study, I do not think such omissions have materially affected the results of my study, given the comprehensiveness of my review. 

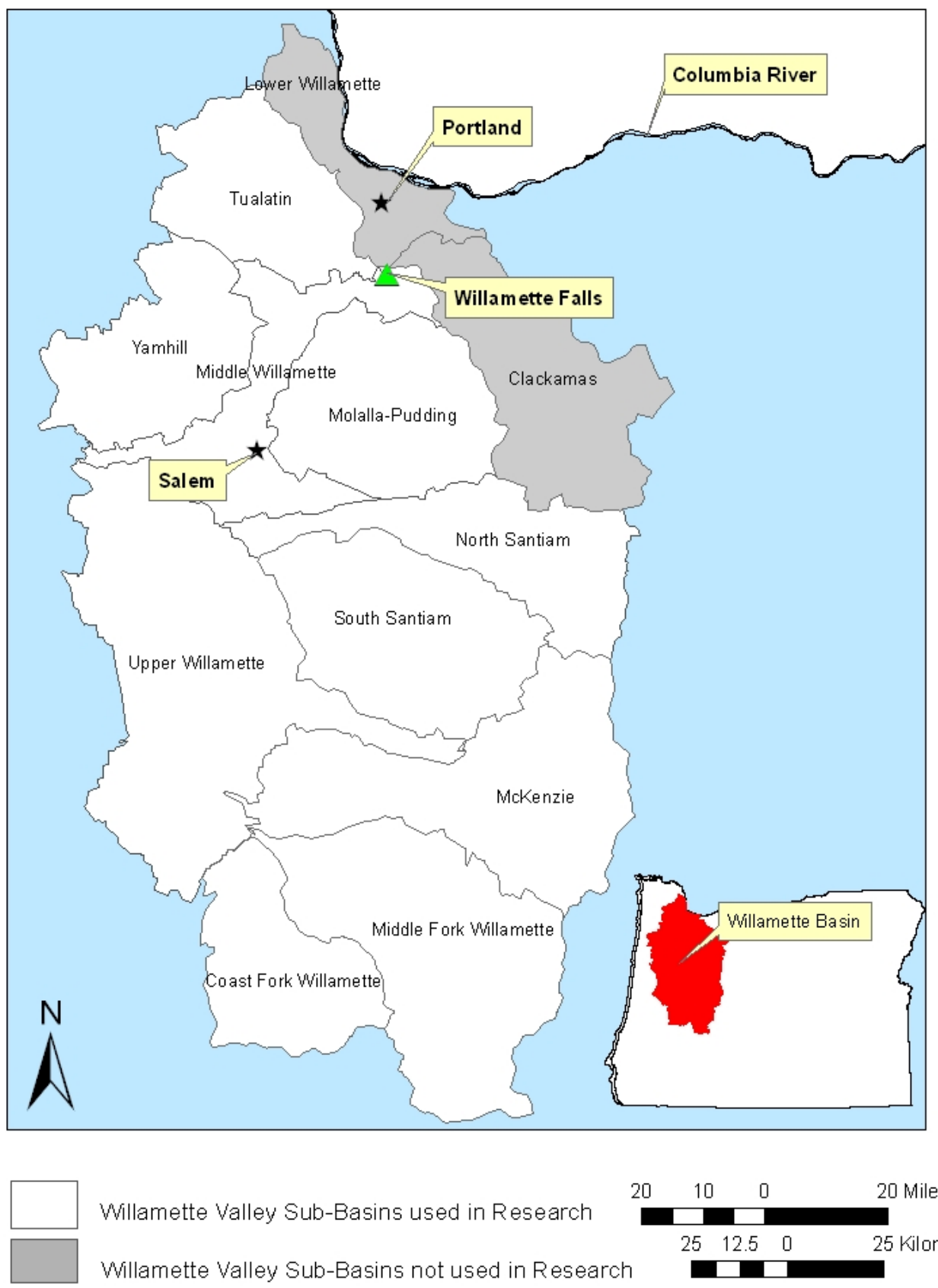

Willamette Valley Sub-Basins used in Research

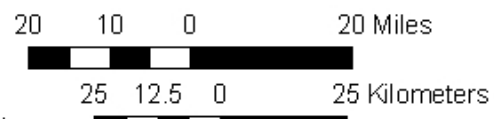

Willamette Valley Sub-Basins not used in Research

Figure 2. Location of Willamette Valley Sub-Basins 
I then queried site numbers that fell within these polygons. Basin polygons were collected from the USGS National Hydrograpic Dataset (http://nhd.usgs.gov/data.html). The site lists generated were then crosschecked using the SHPO's bibliographic software to locate associated archaeological investigation reports.

From this list, I closely examined all reports with excavated site contents, including shovel test pits and shovel test units, unless they were reporting on Euro-American historical sites, which would not yield Native subsistence data. Historical site reports were omitted from further analysis.

From each site report, I obtained information on the following attributes: collection method, mesh size, area and volume sampled. I also recorded information on site chronology, plant remains, and fish-related artifacts if present. Site chronology is needed to establish the timing of subsistence changes, especially the possibility that salmon passage was affected by sea level change. Recording plant tissue information provides knowledge on the extent of non-animal food consumption. Finally, several reports included information on animal protein residue. This information was recorded as well, since this information could also help address whether the native peoples of the Willamette Valley used salmon.

Once reports were collected from the Oregon SHPO and recorded, I noted the number of reports that listed the mesh size used in the excavation 
as less than or equal to $1 / 4 "$, as well as listed the volume of soil excavated. A maximum threshold for mesh size of $1 / 4$ " was selected because use of larger mesh or no screening at all limits one's ability to recover salmon remains, therefore making it impossible to determine whether absence of salmon in the archaeological record is a function of cultural processes, post depositional processes, or archaeological sampling methods. Site reports that omitted information on excavated volume, screen mesh size, or did not collect faunal remains were noted, but would not have been used to assess the size of the faunal sample had there been more faunal data in the Willamette Valley, unless salmon remains were recovered during excavation. The reasoning behind including site records with salmon remains that lack sample design information is that sample size assessment becomes unnecessary if salmon remains are present, given that the overall goal is to determine whether salmon were used prehistorically. Once I located and tallied all sites that had faunal remains from excavation reports, I listed the contents of sites that had faunal remains that were identified to a taxonomic group (Table 2). Sites with faunal remains that were not identified to a taxonomic level, remains that were identified but not counted, or remains that were clearly associated with historic occupations in multi-component sites were included in the tally for the total number of sites with faunal remains, and were used to explore faunal preservation in the Willamette Valley. 
After compiling the site report information, I used ArcMap to determine the distribution of sites with faunal remains on the landscape relative to the Willamette River and its tributaries (the source of salmon) to better assess whether sites are in appropriate locations for the detection of salmon remains. Using the distance measuring function on ArcMap, I recorded the distance between sites and the nearest salmon source. If multiple sites with faunal remains were located near a salmon source, this would support the case that archaeological locations and preservation were not responsible for scarce or absent salmon remains.

After analyzing the site records of the Willamette Valley, I determined which factors (number of sites, mean volume excavated, mesh size), which I could control for, had the strongest effect on faunal representation. To do this, I cross-compared the number of sites with faunal remains in each sub-basin with the number of sites, mean volume excavated, and mesh size using a scatter-plot diagram. I used the linear regression analysis tool in Microsoft Excel to determine the slope of the line formed by the sequential alignment of the independent numerical variable, in ascending order, of the nine sub-basins to determine the correlation coefficient $\left(R^{2}\right)$ for each value paired with number of sites with faunal remains.

To estimate the amount of error in my data collection I re-analyzed a ten percent sample of reports, selected using a random number generator provided by Random.org. I recorded 18 out of 19 attribute categories for each 
site. This sample size was selected out of convenience, but it represents a $20 \%$ margin of error using a $95 \%$ confidence interval

(http://www.raosoft.com/samplesize.html). Of the sites selected, a single error was found relating to reported mesh size at 35-LA-71, representing a recording error of $1 / 5^{\text {th }}$ of one percent (or $1 / 504$ ).

\section{Results}

Records Compilation

A total of 286 sites in the Willamette Valley have received some subsurface testing (e.g., shovel test pits, shovel test units) (Table 1). The following highlights specific results by sub-basin. 
Table 1. Willamette Valley Archaeological Sites Summary Table

\begin{tabular}{|c|c|c|c|c|c|c|c|c|c|}
\hline Sub-Drainage & $\begin{array}{c}\# \\
\text { excavated } \\
\text { sites }\end{array}$ & $\begin{array}{l}\text { \# sites, } \\
\text { mesh size } \\
\leq 1 / 4 ”\end{array}$ & $\begin{array}{l}\text { \# sites with } \\
\text { volume } \\
\text { information }\end{array}$ & $\begin{array}{c}\text { Total } \\
\text { Volume } \\
\text { (mean) } \mathrm{m}^{3}\end{array}$ & $\begin{array}{l}\text { \# sites that } \\
\text { list volume } \\
\text { and mesh } \\
\text { size }\end{array}$ & $\begin{array}{c}\text { \# sites with } \\
\text { faunal } \\
\text { remains }\end{array}$ & $\begin{array}{l}\text { \# sites } \\
\text { with plant } \\
\text { remains }\end{array}$ & $\begin{array}{l}\text { \# sites } \\
\text { with } \\
\text { fishing } \\
\text { gear }\end{array}$ & $\begin{array}{c}\text { \# sites, } \\
\text { lithics - } \\
\text { fish residue }\end{array}$ \\
\hline $\begin{array}{c}\text { Mid } \\
\text { Willamette }\end{array}$ & 68 & 50 & 39 & $108.2(2.8)$ & 29 & 13 & 7 & 0 & 2 \\
\hline $\begin{array}{l}\text { North } \\
\text { Santiam }\end{array}$ & 24 & 20 & 16 & $40.5(2.5)$ & 16 & 3 & 4 & 0 & 3 \\
\hline $\begin{array}{c}\text { South } \\
\text { Santiam }\end{array}$ & 37 & 34 & 22 & 43.9 (2) & 20 & 3 & 0 & 0 & 0 \\
\hline McKenzie & 33 & 31 & 27 & $66(2.4)$ & 22 & 2 & 0 & 0 & 0 \\
\hline Coast Fork & 14 & 13 & 11 & $25.8(2.3)$ & 11 & 1 & 0 & 0 & 0 \\
\hline Middle Fork & 39 & 30 & 14 & 31.7 (2.3) & 14 & 7 & 6 & 1 & 0 \\
\hline Molalla & 3 & 3 & 0 & N/A & 0 & 1 & 0 & 0 & 0 \\
\hline Tualatin & 6 & 5 & 4 & $13.8(3.5)$ & 4 & 2 & 1 & 0 & 0 \\
\hline Yamhill & 14 & 9 & 2 & $3.2(1.7)$ & 2 & 0 & 0 & 1 & 0 \\
\hline $\begin{array}{c}\text { Upper } \\
\text { Willamette }\end{array}$ & 48 & 46 & 30 & $164.4(5.5)$ & 28 & 7 & 5 & 0 & 0 \\
\hline Total & 286 & 241 & 165 & $497.5(3)$ & 146 & 39 & 23 & 2 & 5 \\
\hline
\end{tabular}

$\omega$ 


\section{Mid-Willamette Valley}

Faunal materials were identified in 13 sites. However, with the exception of two sites, materials were not identified to a taxonomic group beyond "'small", "medium" or "large" mammal. In addition, explicit discussion of faunal analysis methods was rare. A single "pig" tooth was identified at 35PO-83 (McCormick and Roulette 2008), which was attributed to a historic occupation. A canine (taxon unspecified) tooth was identified at 35-PO-3 (Thoms and Carlevato 1981). Multiple faunal remains were identified to the genus taxonomic level at 35-LIN-468 (Fagan et al. 1992).

Botanical remains were identified at seven sites. Camas (Camassia quamash) was the most commonly reported plant, followed by hazelnut (Corylus cornuta). Three net weights were recovered from 35-MA-57 (Bell, No Date). Tools analyzed for blood residue tested positive for "trout" at sites 35LIN-451 and 470 (Fagan et al. 1992).

The Mid-Willamette region had the largest number of sites, as well as sites with faunal remains and plant remains, relative to the other Willamette sub-drainage regions.

North Santiam

Faunal materials were identified in three sites. The majority of the bone was identified as "small", "medium" or "large" mammal. Bovine bone was identified at 35-MA-107 and 35-MA-114 (Fagan et al. 1992). One site (35-MA- 
92) had faunal materials, however no fauna were identified at a level finer than vertebrate class (Silvermoon 1990).

Botanical remains were identified at four sites, including camas, hazelnut, chokecherry (Prunus virginiana), English walnut (Juglans regia), salmonberry (Rubus spectabilis), red cedar (Thuja plicata) and Douglas fir (Pseudotsuga menziesii). Tools analyzed for blood residue tested positive for "Trout" at sites 35-MA-105, 107, and 114 (Fagan et al. 1992).

One site (35-MA-107), located in the North Santiam sub-drainage, was also listed in the Mid-Willamette dataset. Information about this site is provided in two reports I included site records in the North Santiam dataset.

South Santiam

Three sites, 35-LIN-363 (Winthrop and Gray 1988), 391 (Flenniken et al. 1990), and 660 (O'Neill and Jenkins 2001), had faunal remains, the majority of which were identified as "medium mammal bone." A single squirrel (Sciuridae) incisor was found at 35-LIN-660.

McKenzie

Two sites (35-LA-390, 951) had faunal remains. Three faunal specimens identified to the group taxon Catostomidae/Cyprinidae were found at 35-LA-951 (Toepel and Bland 1991). Site 35-LA-390 had a single faunal fragment not identified to taxon or element (Jenkins 1986). 


\section{Coast Fork}

A single site (35-LA-1228) had a single faunal fragment that could not be identified to taxon or element (Tasa and Connolly 2000).

\section{Middle Fork}

Seven sites had faunal remains (35-LA-39, 190, 191, 656, 801, 802, and 1026), and two (35-LA-801 and 802) had associated faunal tables with fragments that were identified to species (Churchill and Jenkins 1989).

Six sites had floral remains, but only one site (35-LA-802) listed the results of floral analysis in the report. Hazelnut and Douglas fir were found at this site. A single net-sinker was found at 35-LA-285 (Winkler 2005).

Molalla

A single site (35-CL-122) yielded faunal remains that were not identified to taxon or element (Fagan et al. 1992).

Site 35-MA-94 was also listed for the Mid-Willamette drainage, and the site was documented in two reports. I placed both site records in the Molalla drainage dataset.

No soil volume was recorded from reports in this sub-basin.

Tualatin

Two sites $(35-\mathrm{WN}-4,45)$ had bone fragments that were not identified to taxon or element. 
Floral remains (acorn shells) were recovered from one site, 35-WN-45 (Ellis and Forgeng 1998). A single "ball", referred to as a net-weight, was located at 35-WN-4 (Davis 1970).

Blood residue analysis was carried out on lithics at 35-WN-45, which tested positive for duck (Family Anatidae) or pigeon (Family Columbidae) residue.

Yamhill

Faunal remains were not found at any site in the Yamhill sub-basin.

Upper Willamette

Seven sites (35-BE-10, 37, 39, 35-LA-218,1283, 35-LIN-659, 683) had faunal remains. Of these, five sites (35-BE-10, 37, 39, 35-LA- 218, 1283) had faunal remains that were identified to the genus or species level.

Floral remains were found in five sites (35-LA-42, 626, 628, 683, and 1283). Camas was the most commonly identified plant.

The Upper Willamette sub-basin had the second highest number of sites when compared to other sub-basins. In addition, the Upper Willamette sub-basin had, by far, the highest mean soil volume excavated per site when compared to the other sub-basins, an attribute that may help to explain why it also had the most sites with faunal remains that could be identified to a genus or species level. 
Summary of Willamette Valley Faunal Assemblages

Thirty-nine out 286 sites (or around 15\%) that have received some subsurface testing have faunal remains (Table 1). Mesh size and volume excavated were listed for 28 of these. Of the 39 sites with faunal remains, 26 either had a faunal assemblage that was too fragmentary to identify to any taxonomic level, remains that were identified as present but not quantified, or remains that were clearly associated with historic occupations. The remaining thirteen sites provided very few identified faunal remains $(n=373)$ and no salmon remains (Table 2). 
Table 2. Summary of Identified Faunal Remains in Willamette Valley Archaeological Sites

\begin{tabular}{|c|c|c|c|c|c|c|c|c|c|c|c|c|c|c|}
\hline Sub-Drainage & $\begin{array}{c}\text { Mid- } \\
\text { Willamette }\end{array}$ & $\begin{array}{c}\text { Upper } \\
\text { Willamette }\end{array}$ & $\begin{array}{l}\text { Middle } \\
\text { Fork }\end{array}$ & $\begin{array}{l}\text { Middle } \\
\text { Fork }\end{array}$ & $\begin{array}{l}\text { Middle } \\
\text { Fork }\end{array}$ & $\begin{array}{l}\text { Middle } \\
\text { Fork }\end{array}$ & $\begin{array}{l}\text { Middle } \\
\text { Fork }\end{array}$ & $\begin{array}{c}\text { S. } \\
\text { Santiam }\end{array}$ & $\begin{array}{c}\text { Upper } \\
\text { Willamette }\end{array}$ & $\begin{array}{c}\text { Upper } \\
\text { Willamette }\end{array}$ & $\begin{array}{c}\text { Upper } \\
\text { Willamette }\end{array}$ & $\begin{array}{c}\text { Upper } \\
\text { Willamette }\end{array}$ & \multirow{2}{*}{\multicolumn{2}{|c|}{$\begin{array}{c}\text { McKenzie } \\
\text { 35-LA- } \\
951\end{array}$}} \\
\hline Site & 35-LIN-468 & 35-LA-218 & $\begin{array}{l}\text { 35-LA- } \\
801\end{array}$ & $\begin{array}{l}\text { 35-LA- } \\
802\end{array}$ & $\begin{array}{c}35-\text { LA- } \\
190\end{array}$ & $\begin{array}{c}\text { 35-LA- } \\
191\end{array}$ & $\begin{array}{c}\text { 35-LA- } \\
656\end{array}$ & $\begin{array}{c}35 \text {-LIN- } \\
660\end{array}$ & $\begin{array}{c}\text { 35-LA- } \\
1283\end{array}$ & 35-BE-10 & 35-BE-37 & 35-BE-39 & & \\
\hline $\begin{array}{l}\text { Citation } \\
\text { Page No. }\end{array}$ & $\begin{array}{c}\text { Fagan et al } \\
1996 \\
\text { Appendix }\end{array}$ & $\begin{array}{c}\text { Toepel \& } \\
\text { Minor } 1980 \\
\text { 196-201 }\end{array}$ & $\begin{array}{c}\text { Churchill } \\
\text { \& Jenkins } \\
1989 \text { p. } \\
101-110\end{array}$ & $\begin{array}{c}\text { Churchill } \\
\text { \& Jenkins } \\
1989 \text { p. } \\
101-110\end{array}$ & $\begin{array}{c}\text { Churchill } \\
1989 \text { p. } \\
36-37\end{array}$ & $\begin{array}{c}\text { Churchill } \\
1989 \text { p. } \\
47-48\end{array}$ & $\begin{array}{c}\text { Churchill } \\
1989 \\
\text { p.63-64 }\end{array}$ & $\begin{array}{c}\text { O'Neill } \\
\& \\
\text { Jenkins } \\
2001\end{array}$ & $\begin{array}{l}\text { Oetting } \\
2005 a\end{array}$ & $\begin{array}{c}\text { Havercroft } \\
1985\end{array}$ & $\begin{array}{c}\text { Havercroft } \\
1985\end{array}$ & $\begin{array}{c}\text { Havercroft } \\
1985\end{array}$ & $\begin{array}{c}\text { Toepel \& } \\
\text { Bland }\end{array}$ & Total \\
\hline Mesh Size & Unlisted & $1 / 4^{\prime \prime}$ & $1 / 8^{\prime \prime}$ & $1 / 8^{\prime \prime}$ & $1 / 8^{\prime \prime}$ & $1 / 8^{\prime \prime}$ & $1 / 8^{\prime \prime}$ & $1 / 8^{\prime \prime}$ & $1 / 8^{\prime \prime}$ & $1 / 4^{\prime \prime}$ & $1 / 4^{\prime \prime}$ & $1 / 4^{\prime \prime}$ & Unlisted & \\
\hline $\begin{array}{l}\text { Mammalia } \\
\text { Equus ferus } \\
\text { caballus }\end{array}$ & & 2 & & & & & & & & & & 2 & & \\
\hline Bison bison & & 3 & & & & & & & & & & 1 & & \\
\hline Bos taurus & 2 & 1 & & & & & & & & & & & & \\
\hline $\begin{array}{l}\text { Ursidae } \\
\text { Ursus } \\
\text { horribilis } \\
\text { Ursus } \\
\text { americanus }\end{array}$ & $\begin{array}{l}1 \\
3 \\
1\end{array}$ & & 1 & & & & & & & & & & & \\
\hline Artiodactyla & & 1 & & & & & & & & & & & & \\
\hline $\begin{array}{l}\text { Cervidae } \\
\text { Urocyon } \\
\text { cineroargentus } \\
\text { Cervus } \\
\text { canadensis } \\
\text { Odocoileus }\end{array}$ & 3 & & & & & & 1 & & & & & & & \\
\hline $\begin{array}{l}\text { spp } \\
\text { Odocoileus } \\
\text { hemionus }\end{array}$ & 9 & 12 & 17 & 3 & & 2 & 25 & & 1 & & & 21 & & \\
\hline Canis sp. & 5 & 13 & & & & & & & & & & & & \\
\hline $\begin{array}{l}\text { Lynx rufus } \\
\text { Lynx } \\
\text { candensis } \\
\text { candensis }\end{array}$ & 5 & & 2 & & & & 1 & & & & & & & \\
\hline $\begin{array}{l}\text { Mustelidae } \\
\text { Lutra } \\
\text { canadensis } \\
\text { Castor } \\
\text { canadensis }\end{array}$ & $\begin{array}{l}1 \\
1 \\
3\end{array}$ & 1 & & & & & & & & & & & & \\
\hline
\end{tabular}




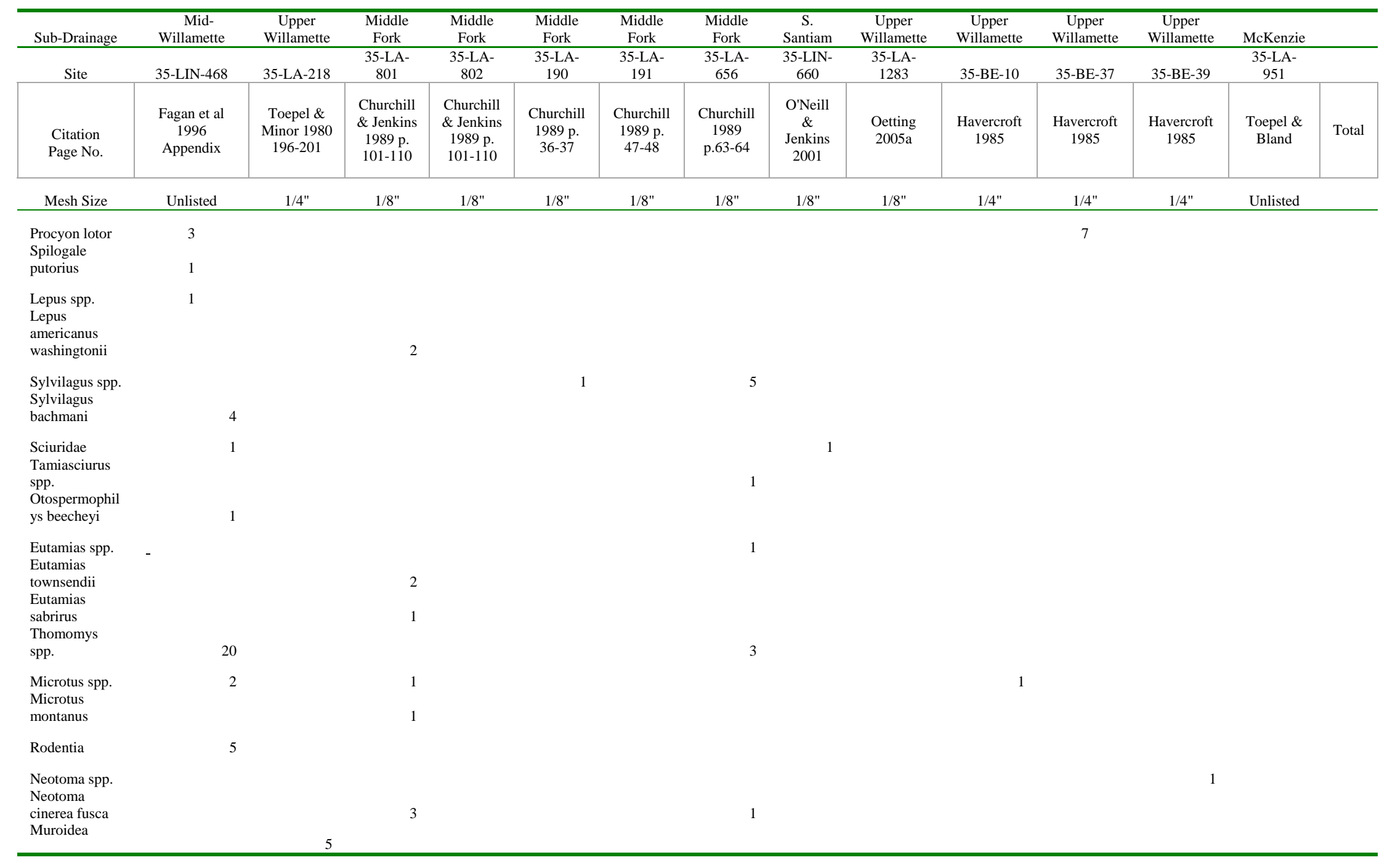

N 


\begin{tabular}{|c|c|c|c|c|c|c|c|c|c|c|c|c|c|c|}
\hline Sub-Drainage & $\begin{array}{c}\text { Mid- } \\
\text { Willamette }\end{array}$ & $\begin{array}{c}\text { Upper } \\
\text { Willamette }\end{array}$ & $\begin{array}{l}\text { Middle } \\
\text { Fork }\end{array}$ & $\begin{array}{l}\text { Middle } \\
\text { Fork }\end{array}$ & $\begin{array}{l}\text { Middle } \\
\text { Fork }\end{array}$ & $\begin{array}{l}\text { Middle } \\
\text { Fork }\end{array}$ & $\begin{array}{l}\text { Middle } \\
\text { Fork }\end{array}$ & $\begin{array}{c}\text { S. } \\
\text { Santiam }\end{array}$ & $\begin{array}{c}\text { Upper } \\
\text { Willamette }\end{array}$ & $\begin{array}{c}\text { Upper } \\
\text { Willamette }\end{array}$ & $\begin{array}{c}\text { Upper } \\
\text { Willamette }\end{array}$ & $\begin{array}{c}\text { Upper } \\
\text { Willamette }\end{array}$ & \multirow{2}{*}{\multicolumn{2}{|c|}{$\begin{array}{c}\text { McKenzie } \\
\text { 35-LA- } \\
951\end{array}$}} \\
\hline Site & 35-LIN-468 & 35-LA-218 & $\begin{array}{c}\text { 35-LA- } \\
801\end{array}$ & $\begin{array}{c}\text { 35-LA- } \\
802\end{array}$ & $\begin{array}{c}35-\mathrm{LA}- \\
190\end{array}$ & $\begin{array}{c}\text { 35-LA- } \\
191\end{array}$ & $\begin{array}{c}\text { 35-LA- } \\
656\end{array}$ & $\begin{array}{l}\text { 35-LIN- } \\
660\end{array}$ & $\begin{array}{c}\text { 35-LA- } \\
1283\end{array}$ & 35-BE-10 & 35-BE-37 & 35-BE-39 & & \\
\hline $\begin{array}{l}\text { Citation } \\
\text { Page No. }\end{array}$ & $\begin{array}{c}\text { Fagan et al } \\
1996 \\
\text { Appendix }\end{array}$ & $\begin{array}{c}\text { Toepel \& } \\
\text { Minor } 1980 \\
\text { 196-201 }\end{array}$ & $\begin{array}{c}\text { Churchill } \\
\text { \& Jenkins } \\
1989 \text { p. } \\
101-110\end{array}$ & $\begin{array}{c}\text { Churchill } \\
\text { \& Jenkins } \\
1989 \mathrm{p} . \\
101-110\end{array}$ & $\begin{array}{c}\text { Churchill } \\
1989 \mathrm{p} . \\
36-37\end{array}$ & $\begin{array}{c}\text { Churchill } \\
1989 \mathrm{p} . \\
47-48\end{array}$ & $\begin{array}{c}\text { Churchill } \\
1989 \\
\text { p.63-64 }\end{array}$ & $\begin{array}{c}\text { O'Neill } \\
\& \\
\text { Jenkins } \\
2001\end{array}$ & $\begin{array}{l}\text { Oetting } \\
\text { 2005a }\end{array}$ & $\begin{array}{c}\text { Havercroft } \\
1985\end{array}$ & $\begin{array}{c}\text { Havercroft } \\
1985\end{array}$ & $\begin{array}{c}\text { Havercroft } \\
1985\end{array}$ & $\begin{array}{c}\text { Toepel \& } \\
\text { Bland }\end{array}$ & Total \\
\hline Mesh Size & Unlisted & $1 / 4^{\prime \prime}$ & $1 / 8^{\prime \prime}$ & $1 / 8^{\prime \prime}$ & $1 / 8^{\prime \prime}$ & $1 / 8^{\prime \prime}$ & $1 / 8^{\prime \prime}$ & $1 / 8 "$ & $1 / 8^{\prime \prime}$ & $1 / 4^{\prime \prime}$ & $1 / 4^{\prime \prime}$ & 1/4" & Unlisted & \\
\hline $\begin{array}{l}\text { Peromyscus } \\
\text { maniculatus } \\
\text { Scapanus } \\
\text { townsendi }\end{array}$ & 7 & & 1 & & & & & & & & & & & \\
\hline Cricetidae & & 43 & & & & & & & & & & & & \\
\hline $\begin{array}{l}\text { Sorex spp. } \\
\text { Spermophilus } \\
\text { spp. }\end{array}$ & 1 & 2 & & & & & & & & & & 4 & & \\
\hline Aves & & & & & & & & & & & & & & \\
\hline Gallus gallus & 1 & & & & & & & & & & & & & \\
\hline Anatidae & 1 & & & & & & & & & & & & & \\
\hline $\begin{array}{l}\text { Anserinae } \\
\text { Branta } \\
\text { canadensis } \\
\text { Chen } \\
\text { caerulescens }\end{array}$ & 3 & & & & & & & & & & & & & \\
\hline Anas spp. & 3 & & & & & & & & & & & & & \\
\hline $\begin{array}{l}\text { Anas crecca } \\
\text { Anas } \\
\text { platyrhynchos }\end{array}$ & & 11 & & & & & & & & & & & & \\
\hline Anas acuta & 1 & & & & & & & & & & & & & \\
\hline Aix sponsa & & 1 & & & & & & & & & & & & \\
\hline $\begin{array}{l}\text { Accipitrinae } \\
\text { Dendragapus } \\
\text { obscurus } \\
\text { Agelaius } \\
\text { phoeniceus }\end{array}$ & 1 & $\begin{array}{r}8 \\
12\end{array}$ & & & & & & & & & & & & \\
\hline
\end{tabular}

$\omega$ 


\begin{tabular}{|c|c|c|c|c|c|c|c|c|c|c|c|c|c|c|}
\hline Sub-Drainage & $\begin{array}{c}\text { Mid- } \\
\text { Willamette }\end{array}$ & $\begin{array}{c}\text { Upper } \\
\text { Willamette }\end{array}$ & $\begin{array}{l}\text { Middle } \\
\text { Fork }\end{array}$ & $\begin{array}{l}\text { Middle } \\
\text { Fork }\end{array}$ & $\begin{array}{l}\text { Middle } \\
\text { Fork }\end{array}$ & $\begin{array}{l}\text { Middle } \\
\text { Fork }\end{array}$ & $\begin{array}{l}\text { Middle } \\
\text { Fork }\end{array}$ & $\begin{array}{c}\text { S. } \\
\text { Santiam }\end{array}$ & $\begin{array}{c}\text { Upper } \\
\text { Willamette }\end{array}$ & $\begin{array}{c}\text { Upper } \\
\text { Willamette }\end{array}$ & $\begin{array}{c}\text { Upper } \\
\text { Willamette }\end{array}$ & $\begin{array}{c}\text { Upper } \\
\text { Willamette }\end{array}$ & \multicolumn{2}{|l|}{ McKenzie } \\
\hline Site & 35-LIN-468 & 35-LA-218 & $\begin{array}{c}\text { 35-LA- } \\
801\end{array}$ & $\begin{array}{c}\text { 35-LA- } \\
802\end{array}$ & $\begin{array}{c}\text { 35-LA- } \\
190\end{array}$ & $\begin{array}{c}\text { 35-LA- } \\
191\end{array}$ & $\begin{array}{c}\text { 35-LA- } \\
656\end{array}$ & $\begin{array}{c}\text { 35-LIN- } \\
660\end{array}$ & $\begin{array}{c}35-\mathrm{LA}- \\
1283\end{array}$ & 35-BE-10 & 35-BE-37 & 35-BE-39 & \multicolumn{2}{|l|}{$\begin{array}{c}\text { 35-LA- } \\
951\end{array}$} \\
\hline $\begin{array}{l}\text { Citation } \\
\text { Page No. }\end{array}$ & $\begin{array}{c}\text { Fagan et al } \\
1996 \\
\text { Appendix }\end{array}$ & $\begin{array}{c}\text { Toepel \& } \\
\text { Minor } 1980 \\
196-201\end{array}$ & $\begin{array}{c}\text { Churchill } \\
\text { \& Jenkins } \\
1989 \text { p. } \\
101-110\end{array}$ & $\begin{array}{c}\text { Churchill } \\
\text { \& Jenkins } \\
1989 \text { p. } \\
101-110\end{array}$ & $\begin{array}{c}\text { Churchill } \\
\text { 1989 p. } \\
36-37\end{array}$ & $\begin{array}{c}\text { Churchill } \\
1989 \mathrm{p} . \\
47-48\end{array}$ & $\begin{array}{c}\text { Churchill } \\
1989 \\
\text { p.63-64 }\end{array}$ & $\begin{array}{c}\text { O'Neill } \\
\& \\
\text { Jenkins } \\
2001\end{array}$ & $\begin{array}{l}\text { Oetting } \\
\text { 2005a }\end{array}$ & $\begin{array}{c}\text { Havercroft } \\
1985\end{array}$ & $\begin{array}{c}\text { Havercroft } \\
1985\end{array}$ & $\begin{array}{c}\text { Havercroft } \\
1985\end{array}$ & $\begin{array}{c}\text { Toepel \& } \\
\text { Bland }\end{array}$ & Total \\
\hline Mesh Size & Unlisted & $1 / 4^{\prime \prime}$ & $1 / 8^{\prime \prime}$ & $1 / 8^{\prime \prime}$ & $1 / 8^{\prime \prime}$ & $1 / 8^{\prime \prime}$ & $1 / 8^{\prime \prime}$ & $1 / 8^{\prime \prime}$ & $1 / 8^{\prime \prime}$ & $1 / 4^{\prime \prime}$ & $1 / 4^{\prime \prime}$ & $1 / 4^{\prime \prime}$ & \multicolumn{2}{|l|}{ Unlisted } \\
\hline
\end{tabular}

Fish

Cyprinidae

Catostomus

spp.

Reptilia

Testudinidae

occidentali

36

Total
Number of

species

24

$152 \quad 31$

$31 \quad 3$

1

\begin{tabular}{rrr}
3 & 38 & 1 \\
2 & 8 & 1 \\
\hline
\end{tabular}

\begin{tabular}{rrrrrr}
1 & 1 & 7 & 29 & 3 & 373 \\
1 & 1 & 1 & 5 & 2 & \\
\hline
\end{tabular}


The distribution of faunal remains in Willamette Valley archaeological sites is highly uneven and patterned. With the exception of 35-LA-218, all sites with more than five identified faunal specimens were located in caves or rock shelters. This finding is consistent with Lyman's records for areas southwest of the Willamette Valley. The majority of identified faunal remains (255 out of 373) were located at two sites, 35-LIN-468 (Fagan et al. 1992) and 35-LA-218 (Toepel and Minor 1980). Seven of the remaining sites had less than five identified faunal specimens. Of the remaining four excavated sites with identified faunal remains, deer (Odocoileus sp.) is the most commonly identified taxon, as well as one of the most abundant, while the order Rodentia is the most common order represented (Table 2).

Of 13 sites with identified faunal remains, six could be located on the Oregon SHPO GIS system as site points (Table 3). An additional site (35-LA656) was placed near Deadhorse Creek, based on information in the site report (Churchill 1989). The remaining six could not be isolated to a single point, since they were attributed to polygons that signified survey dimensions, which could stretch over many acres of land. Distance from the nearest river or large stream varied from 2300 m (35-LA-1283) to 220 m (35-LIN-468). It appears that, with the exception of 35-LA-802 and 1283, most of the sites with faunal remains are within walking distance, but not immediately adjacent to a place where salmon could have been exploited. 
Table 3. Distance of Sites with Faunal Remains from a River

\begin{tabular}{cl}
\hline Site Number & \multicolumn{1}{c}{ Distance from River (and potential salmon source) } \\
\hline 35-LIN-468 & 220 m from Calapooia River \\
35-LIN-660 & $252 \mathrm{~m}$ from Oak Creek, Tributary of South Santiam River \\
35-LA-190 & $\begin{array}{l}\text { 469 m from tributary Middle Fork Willamette (Reservoir area, unable to } \\
\text { determine original river location) }\end{array}$ \\
35-LA-191 & $\begin{array}{l}572 \mathrm{~m} \text { from tributary of Middle Fork Willamette (Reservoir area, unable to } \\
\text { determine original river location) }\end{array}$ \\
35-LA-656 & $\begin{array}{l}\text { No site point in database. Very near Deadhorse creek (Churchill 1989) } \\
\text { 35-LA-802 }\end{array}$ \\
1048 m from Middle Fork Willamette River \\
35-LA-1283 & $2300 \mathrm{~m}$ from McKenzie River
\end{tabular}

Trends in Sub-Basin Data

In order to determine how excavation methods and volume excavated affect faunal representation, I analyzed the relationship between number of sites with faunal remains and total number of sites per sub-basin as well as total number of sites that listed mesh size and volume excavated per subbasin. It is expected that as excavated volume increases, so should the number and variety of artifact types (Lyman 1995). This can be analyzed in two ways, first an increase in the total number of excavated sites in a region should suggest that more volume has been excavated than in regions with fewer sites. Second, if excavated volume is recorded, one could contrast either the total volume excavated from a region, or the mean volume per site in a region with the number of sites with faunal remains. In addition to volume, mesh size should have an effect on the number and variety of artifacts. As mesh size decreases, the number and variety of artifacts should increase 
(Lyman 1995). In the succeeding section, I analyze which factors affect faunal representation in the Willamette Valley.

The distribution and number of sites with faunal remains is strongly related to the total number of sites tested in each of the Willamette Sub-basins (Figure 3, Table $4, R^{2}=0.8041, p=0.0008$ ). On the other hand, there is a weaker relationship between the number of sites that had been excavated using $1 / 4$ " mesh screens, and had recorded the volume excavated versus the number of sites with faunal remains (Figure $4, R^{2}=0.5359, p=.0558$ ). 


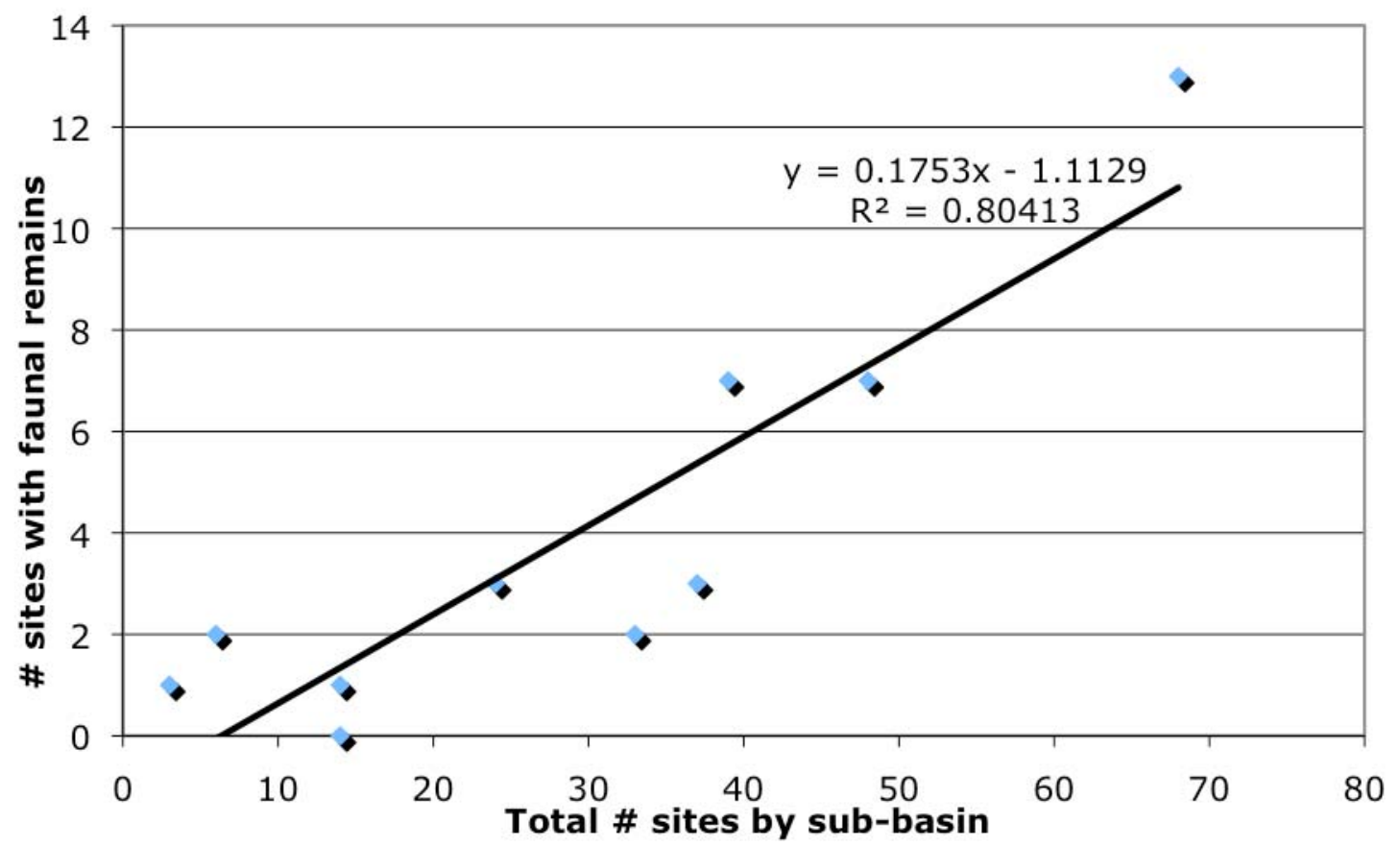

Figure 3. Relationship Between Number of Sites with Faunal Remains and Total Number of Sites by Sub-Basin

Table 4. Number of Excavated Sites vs. Number of Sites within Sub-basin with Faunal Remains

\begin{tabular}{ccc}
$\begin{array}{c}\text { Sub- } \\
\text { Drainage }\end{array}$ & $\begin{array}{c}\text { \# excavated } \\
\text { sites }\end{array}$ & $\begin{array}{c}\text { \# sites with } \\
\text { faunal } \\
\text { remains }\end{array}$ \\
\hline $\begin{array}{c}\text { Mid } \\
\text { Willamette }\end{array}$ & 3 & 1 \\
North & & \\
Santiam & 6 & 2 \\
South & & 1 \\
Santiam & 14 & 0 \\
McKenzie & 14 & 3 \\
Coast Fork & 24 & 2 \\
Middle Fork & 33 & 3 \\
Molalla & 37 & 7 \\
Tualatin & 39 & 7 \\
Yamhill & 48 & \\
Upper & & 39 \\
Willamette & 68 &
\end{tabular}


There is not a strong correlation $\left(R^{2}=0.5359, p=0.0558\right)$ between the number of sites that list volume excavated and used a mesh size less than or equal to $1 / 4$ " versus the number of sites with faunal remains (Figure 4).

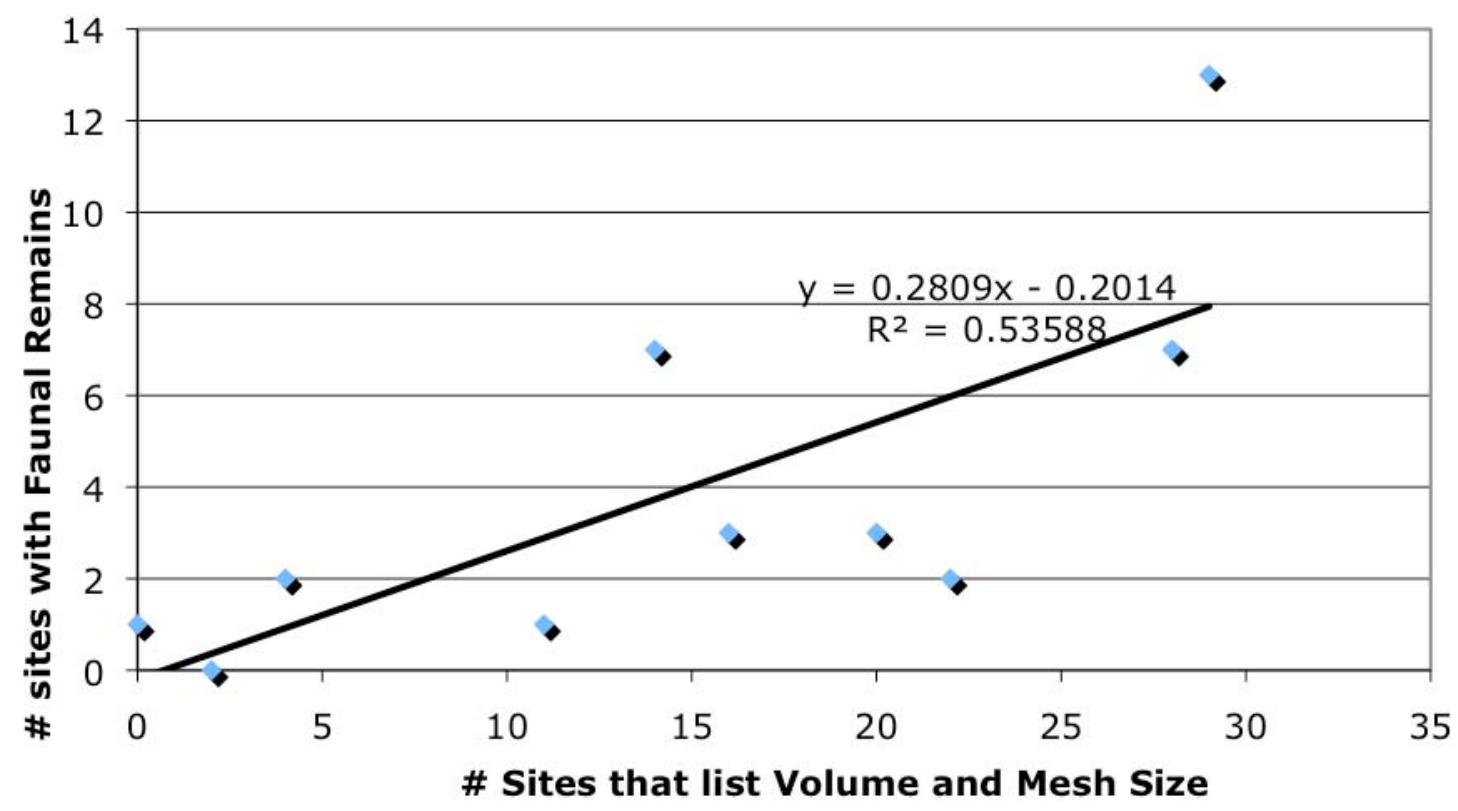

Figure 4. Relationship Between Number of Sites with Faunal Remains and Number of Sites that list Volume and Mesh Size

However, if excavation methods are not reported, this does not affect the outcome of the field methods themselves. Instead, it only affects another researcher's ability to interpret the effect of these methods on the outcome of the excavation.

Finally, there are many factors that affect whether faunal remains are identified, some of which have little to do with the methods used to excavate a site (budget constraints, staff qualifications, preservation). When I compared 
number of sites with identified faunal remains against number of sites, number of sites that listed volume excavated and $1 / 4$ " or smaller mesh, number of sites with faunal remains, and mean volume excavated, all comparisons yielded a very weak correlation.

Overall, my analysis suggests that the factor that most strongly affects the number of sites with faunal remains in a particular sub-basin is the number of sites that have been excavated, an expected finding.

\section{Discussion}

Faunal remains are extremely rare in Willamette Valley archaeological sites. Thirty-nine sites (13.5\%) have faunal remains, and only thirteen sites out of $286(4.5 \%)$ had faunal remains that had been identified to the taxonomic level below class. Seven of these sites have five or fewer identified faunal remains. This leaves five sites, two in the Upper Willamette, one in the MidWillamette, and two in the Middle Fork of the Willamette with potentially enough faunal remains to assess whether salmon were used in the Willamette Valley. All five (35-LIN-468, 35-LA-281, 656, 801, 35-BE-39) of the remaining sites had remains from small and large mammals. Rat, gopher, squirrel, and mole made up the vast majority of small mammal bones. While ethnographic evidence that suggests that small mammals were used by the Native people of the Willamette Valley, it is difficult to determine whether these remains result from human exploitation or post-depositional intrusion. Only site 35-LIN-468 
had a wide variety of small, medium, and large animals that clearly could not have been deposited after human use of the site.

The majority of sites with faunal remains $(n=29,69 \%)$ had faunal remains that were highly fragmented and could only be identified as "medium" or "large" mammals. This level of fragmentation could be related to postdepositional preservation issues, but it may also be the result of human use. Activities such as grease and marrow extraction involve the destruction of faunal remains, resulting in highly fragmented bone pieces (Lyman 1994). Human use, therefore, could play a role in bone preservation in this region.

Since there are so few sites with identified faunal material, and only one site (35-LIN-468) where it is clear that the variety of animal remains present is a direct result of human exploitation, my analysis shows that bone preservation in the Willamette Valley is quite poor, either resulting from natural or behavioral factors. With such a small sample size to analyze, and poor preservation of faunal materials, the Willamette Valley zooarchaeological record is unable to address whether salmon were used by the valley's inhabitants.

Interestingly, while the people of the Willamette Valley are oftentimes portrayed as primarily root eaters based on the ethnohistoric (Coues 1897) and archaeological record (Aikens 1993), compilation of the Willamette Valley archaeological records revealed that there are fewer sites that note plant remains (23), than sites that note faunal remains (39). On the other hand, 
while only 14 out of 39 sites had faunal remains that were identified to a taxonomic family, all sites with plant remains had plants identified to a taxonomic family. The focus on plants in the Willamette Valley archaeological record may be because they are more commonly identified to a taxonomic level than faunal materials, and that the features associated with plant processing are more easily identified than fish capture or fish processing features.

Blood residue analysis from multiple sites in the North Santiam (35MA105, 107, and 114) and mid-Willamette (35MA-451 and 470) drainages yielded positive results for trout residue, corresponding well with Jacob's (1945) ethnographic informants describing salmon use by the Kalapuya of the North Santiam. Williams (1994:3) notes that most antisera used during blood residue analysis reacts only to animals that are within the family group of the control species specimen, a statement with which Fiedel (1997) disagrees (see below). Since salmon and trout belong to family Salmonidae, it is likely that both will elicit a reaction from trout antisera.

While blood residue analysis has been used as a tool in archaeological analysis for nearly 30 years, the reliability of this method has been repeatedly questioned (Reuther et al. 2006). Fiedel (1997) notes that many blood residue tests, including the one run by Williams, use a limited number of antiserum that approximate ethnographically utilized animals, rather than antisera from a variety of animals. Past research has shown that some serums have the 
potential to cross-react with the antiserum of other species (Fiedel 1997, Reuther et al. 2006). Fiedel further argues that without blind tests, which tests blood residue from lithics against a variety of animal residues, including animals that are not expected, blood residue results should be looked at skeptically. Williams (1994) addresses this issue through pre-screening antiserum samples with non-immune serum to determine whether the sample is reacting to non-specific proteins. Whether this was an effective method to deal with cross-reactivity is not addressed in any recent publications. That Reuther et al. (2006) are discussing ways to increase the accuracy of protein residue analysis nearly twelve years after Williams' publication, however, suggests that there are still doubts about the effectiveness of blood residue analysis. 
Chapter 4: Using the Diet Breadth Model from Optimal Foraging Theory to Examine Salmonid use in the Willamette Valley

As considered in previous chapters, the ethnology and archaeological records are limited in their ability to evaluate whether Native peoples of the Willamette Valley relied on salmon for subsistence. The ethnographic record, while helpful for determining what was consumed, is too incomplete to be used to determine what was not consumed. Faunal remains in the archaeological record are scarce, and the sample size too small to draw conclusions about subsistence practices. An alternative way to consider Native American resource use draws on models from optimal foraging theory, a branch of Human Behavioral Ecology. Human Behavioral Ecology (HBE) is a quantitative approach, which assumes that organisms, in this case humans, will respond to their conditions (social and environmental) in fitness enhancing ways (Smith and Winterhalder 2003: 378). Using this framework, one can predict the optimal diet (diet breadth) in a given region based on associated archaeological, ethnographic and/or ecological data, and various assumptions about return rates of plant and animal resources.

Diet breadth analysis in the Willamette Valley has at least three benefits. It can generate expectations about human behavior in situations for which ethnographic and/or archaeological data are scarce. These expectations can be used as a frame of reference with which to assess existing data and common sense perceptions of subsistence in the Willamette 
Valley. Finally, targeted research questions can be generated when incongruities are found between expected subsistence practices and archaeological or ethnographic records for subsistence practices.

Using the diet breadth model, this project will test whether salmon exploitation would have been a viable option for the people of the Willamette Valley given the availability of a variety of resources. If the diet breadth analysis predicts that salmon should have been exploited, I analyze whether there are regional factors which lower the relative rank of salmon, such as lack of availability or increased search or processing time associated with salmon capture. To do this, I describe the resources that are known to have been used in the region, then briefly summarize optimal foraging theory. After this, I present return rate data based on ethnographic records relating to subsistence and the hypothetical addition of salmon. Once these data are presented, I assess whether salmon would have been a viable resource, based on the results of the diet breadth analysis and other factors. Finally, the results of this analysis shows that while salmon exploitation was probably not as profitable as in other areas in the Pacific Northwest, the resource should still have been exploited given its relatively high rank.

\section{Human Behavioral Ecology}

HBE draws its theoretical underpinnings from evolutionary theory, micro-economics, and game theory. HBE research is applied by predicting the optimal behavior at the level of the individual (Smith and Winterhalder 2003: 
378) for a given region and then comparing it to actual behavior. Using this process, one assumes that the organism in question is rational, will optimize its strategy, and prefers evolutionary stable strategies (Smith and Winderhalder 2003: 378). HBE is most commonly applied to issues relating to subsistence in the form of optimal foraging models. Like any other model in HBE, optimal foraging models include a goal, currency, a set of constraints, and a set of options (Kelly 1995:73). Generally, the goal of most models is to maximize foraging efficiency. However, some argue that subsistence strategies are not necessarily maximally efficient, but rather efficient enough for the purposes of the forager. This behavior is called sufficing. The currency for most foraging models is energy, as measured in calories. Constraints can include time, distance, and number of exploitable resources (Kelly 1995:73). The number of exploitable resources also represents the universe of potential exploitation options.

The prey choice, or diet breadth model is designed to predict which food items will be exploited and ignored by foragers. Energy costs in this model include searching and handling, which includes pursuit, capture, and processing for a given food item. This cost is measured by the variable "time", and is considered when calculating caloric gain achieved by exploitation of the resource. Food preference is based upon the net energy return rate from a resource (Kaplan and Hill 2008:169). Only when the resource with a high return rate is depleted, or the return rate declines, will the next highest rated 
resource be selected. The optimal diet would include resources that have a higher return rate than the mean return rate for all possible resources available to the forager (Kaplan and Hill 2008:171). To use this model, it is assumed that searching and handling are mutually exclusive activities, prey are encountered sequentially and randomly, but proportional to their abundance, prey types are not systematically clumped or evenly dispersed, foragers have no impact on resource abundance, and finally, the forager can estimate mean encounter rates, energy returns, and handling costs of resources (Kaplan and Hill 2008:169). It is also important to note that this model will predict diet breadth, but this diversity can change over time (Kelly 1995:87), as some resources are only seasonally, or intermittently, available. For example, in parts of the Great Basin culture area, return rates for grasshoppers range from $41,598 \mathrm{kcal} / \mathrm{hr}$ to $714,409 \mathrm{kcal} / \mathrm{hr}$ during various and unpredictable intervals in the summer (Madsen and Kirkman 1988:600-601).

Madsen and Kirkman (1988) and Simms (1985), among others, have used the diet breadth model to quantify the return rate of a variety of resources for hunter-gatherers after pursuit and processing time have been taken into account. From these data, researchers have constructed models of resource use. It is through these models, that researchers have determined that cost of processing, as well as resource abundance, affects its rank (Jones and Madsen 1989). 
In order to build a diet breadth model, one needs to compile a list of available resources and estimate their rate of return. Prior to estimating return rate, one must decide whether they want to simply present the yield associated with a resource, or a post-processing return rate, which takes factors such as search and handling time into account. In the following section I will estimate the post-processing return rate of the resources available to the Native people of the Willamette Valley.

\section{Methods and Materials}

The subsistence behaviors of native peoples observed by ethnographers and Euro-American explorers will be used as a starting point for my model on the Willamette Valley. Zenk (1990:547) reports vegetable resources were a major portion of Kalapuyan subsistence. As noted in Chapter 2, of particular importance is camas. Wapato (Sagittaria latifolia), tarweed (Madia sativa), hazelnut (Corylus spp.) and berries (e.g., Rubus spp. and Vaccinium spp.) are also believed to have been commonly used plant resources. Acorns (Quercus garryana) were exploited, but considered to be of lesser importance than the above-mentioned resources. Animal resources included duck (Anas spp.), small mammals (gophers, squirrels, hares) deer (Odocoileus spp.), elk or wapiti (Cervus elaphus), black bear (Ursus americanus), grasshoppers (order Orthoptera), lamprey (Lampetra spp.), and caterpillar (Division Ditrysia) (Zenk 1990:548). I have enlarged the list of taxa from Zenk's list to include Chinook salmon to address whether they would 
have been considered a viable resource, since they are available in the region (Table 5).

Table 5. Willamette Valley Resources Considered for Optimal Foraging Model, Based on Zenk (1990)

\begin{tabular}{ll}
\hline Latin Name & Common Name \\
\hline Sagittaria latifolia & Wapato \\
Madia sativa & Tarweed+ \\
Corylus spp. & Hazelnut \\
Rubus spp. & Blackberries, raspberries+ \\
Vaccinium spp. & Blueberries, huckleberries+ \\
Quercus garryana & Oak (Acorns) \\
Camassia quamash & Camas \\
Odocoileus spp. & Deer \\
Cervus elaphus & Elk, Wapiti + \\
Ursus americanus & Black Bear + \\
Order Rodentia & Rodents (eg. gophers, hares, ground squirrels) \\
Anas spp. & Ducks \\
Lampetra spp. & Lamprey+ \\
Oncorhynchus tshawytscha & Chinook salmon \\
Division Ditrysta & Caterpillar*+ \\
order Orthoptera & Grasshoppers*+ \\
\hline + Excluded from model owing to lack of information \\
*Excluded from model because resource was likely minor
\end{tabular}

If possible, I used caloric return rates based on data from or near the Willamette Valley. If this was not possible I included records from other regions. If return rates were not available for a given resource, I estimated values using ethnographic sources. If none of this information was available for a resource, it was excluded from analysis. I was unable to find nutritional or ethnographically described capture and processing times for elk, black bear, lamprey, tarweed, Rubus and Vaccinium berries, and caterpillars, and thus 
these were excluded. I realize the limitations their omission may create and I will consider these below. Details on return rates can be found in the relevant references listed in Appendix B.

In addition to omitting resources for which I could not obtain return rate information, I also omitted post-processing return rate estimations that clearly did not represent the regional abundance of a given species. For example, grasshoppers were excluded form the study for two reasons. First, the only available return rates were from Desert Basin in Utah, conditions drastically different from the Willamette Valley. Second, while Zenk mentions their use, grasshoppers are not abundant in mass such as in the Great Basin and were likely not an important resource in the Willamette Valley.

I used caloric return information for Odocoileus hemionus to represent deer (Odocoileus spp.) in the Willamette Valley, even though two species are located within the Valley. I did this because; 1) both deer species are comparable in size, and 2) I could not find caloric return information for the second species of deer.

One potential problem with my modeling effort relates to a lack of clarity regarding the assumptions and methods used to calculate post-processing return rates. Thoms (1989), Darby (1996) and Lindström (1996) created their own post-processing return rate estimates, with their steps and assumptions included, while Simms (1985) and Kelly (1995) used data relating to return rates that were compiled in other reports. Since there is no mention of how 
return rate was calculated, or of the methods used to calculate in Simms' and Kelly's work, I cannot be sure that the methods used and assumptions made are comparable. I will, for the purpose of this exercise, assume that the presented post-processing return rates are not net energy acquisition rates, which does not take pursuit or processing costs into account. When it is necessary for me to calculate post-processing return rates, I will use Equation 1:

Equation 1

$((\mathrm{Kcal} \times \mathrm{Kg} \mathrm{t}) / \mathrm{lc}) /((\mathrm{t}+\mathrm{pt}) / \mathrm{lp})=\mathrm{PPR}$.

Where, $\mathrm{t}=$ the timeframe (in hours) in which collecting activities took place, $\mathrm{Kg}_{\mathrm{t}}=$ the amount of resources collected (in $\mathrm{kg}$ ) during " $\mathrm{t}$ ", $\mathrm{Kcal}=$ kilocalories derived from $1 \mathrm{~kg}$ of a given resource, $\mathrm{pt}=$ the amount of time needed to process " $\mathrm{Kgt}$ ", Ic $=$ number of individuals associated with collection activities, Ip = number of individuals associated with processing activity, $\mathrm{PPR}=$ post-processing return rate (in $\mathrm{kcal} / \mathrm{hr}$ ) for an individual.

This equation differs slightly from Smith and Winterhalder's (2008:170), in that I explicitly accounted for the number of people associated with collection and processing activities, as reported in ethnographic sources, to generated post-processing return rate for an individual. I did this by dividing the total number of calories extracted from a resource over a given period of time (Kcal $x \mathrm{Kg}_{\mathrm{t}}$ ) by the number of individuals (Ic) associated with this collection activity. If I did not know the number of individuals, I assumed that 
one individual participated in the activity. I used the same method to determine total processing time for each individual associated with processing.

I could not find published post-processing return rate data on native hazelnut, and therefore estimated this value using harvesting estimates by Reidhead (1980) for the hazelnut species Corylus avellan, which potentially differs from the native hazelnut variety. Nutritional values were drawn from the USDA (2009) nutrition value website. Since I could not find data relating to ethnographic processing practices, I assumed negligible processing time, since processing time would consist of cracking the shell to remove the meat, but viewed the results as a rough approximation of caloric returns from hazelnuts given this assumption (Appendix C: Hazelnut Return Rate).

To estimate post-processing return rates for salmon, two sources were available. One was Susan Lindstrom's ethnographic records for salmon fisheries of the Truckee River of the Western Great Basin. A second was from Charles Wilkes, from his observations of fishing at Willamette Falls. I decided to use Wilkes, given the proximity to the research area. For method of salmon capture, I used Jacob's (1945:31) observations that the Kalapuyan people used spears to capture salmon and steelhead. Equipment manufacture and processing times for fish were calculated using estimates from Great Basin ethnographic records (Lindström 1996, Appendix D: Chinook Salmon Return Rate at Willamette Falls). 
It is unlikely that fish exploitation was as productive above the falls as it was at the falls, given that there are few rapids or choke points from which to capture salmon with the use of nets. It is necessary, then, to consider how caloric return rates on salmon would have changed as the point of exploitation moved upriver of the falls. The main difference between a location with a choke point (eg. rapids or the falls) and a location without (above the falls) is the return rate on salmon. This change, however, profoundly affects how salmon are ranked. Because salmon capture records were not available from locations above Willamette Falls, I calculated salmon return rates using ethnohistorical seine fishing catch records in the Snake River in 1894 as cited in Plew (1983). Calculations used to determine Chinook salmon return rates above Willamette Falls can be found in Appendix E.

Finally, when salmon are captured, they can be eaten fresh immediately, or dried, stored and eaten at a later date. Through the process of drying and storing, some of the nutritional value is lost (Plew 1983). In addition, preparing salmon for storage (including processing, drying, and storing), takes more processing time than for fresh salmon. It is, therefore, necessary to calculate the return rate of both fresh and dried salmon.

There is another factor, other than spatial location, that affects a resource's ranking. Resources such as migratory birds, plants, and fish can only be exploited during specific seasons. In the Willamette Valley, the availability of many resources is highly dependent upon seasonality. 
Therefore, calculating and collecting caloric return rates alone would not have been enough to understand the logistical factors that affect resource use in the Willamette Valley. Information on the seasonality of resources is also necessary to understand resource availability over a year. As a result, I also collected information relating to the season in which the various resources were collected. Once this was complete, the twelve month cycle was divided into two-month increments and then I examined the relative rank of resources that would have been exploited during each time segment.

Results

Of the 16 varieties of resources that are known ethnographically to have been used by Native peoples of the Willamette Valley, I obtained enough information to calculate post-processing return rates for nine. These resources included camas, wapato, deer, oak, Anas spp. (ducks and geese), rodents (ground squirrels, gophers, hares, salmon, hazelnut, and grasshoppers (Table $6)$.

As stated above, resource seasonality needs to be considered to better understand when resources would have been available. As shown in Table 6, some resources are available year round, while others are highly seasonal. Generally, floral resources from this region were harvested from late summer to fall. Wapato was the exception, and was harvested from late fall to early spring. With the exception of salmon, there was no mention of the seasonality 
of faunal resources in the ethnographic literature. There was no overlap between the periods where Chinook salmon would have been exploited and the periods when camas would have been exploited. There may have been a slight overlap between the end of the wapato harvest and the beginning of the period when salmon could have been harvested.

Table 6. Willamette Valley Resource Availability in Bi-Monthly Segments

\begin{tabular}{|c|c|c|c|c|c|c|}
\hline Species (Common name) & $\begin{array}{l}\text { January/ } \\
\text { February }\end{array}$ & $\begin{array}{l}\text { March/ } \\
\text { April }\end{array}$ & $\begin{array}{l}\text { May/ } \\
\text { June }\end{array}$ & $\begin{array}{l}\text { July/ } \\
\text { August }\end{array}$ & $\begin{array}{l}\text { September/ } \\
\text { October }\end{array}$ & $\begin{array}{l}\text { November/ } \\
\text { December }\end{array}$ \\
\hline Corylus spp ((Hazelnut) & & & & & $\mathrm{X}$ & \\
\hline Quercus spp. (Oak, acorn) & & & & $\mathrm{X}$ & $\mathrm{X}$ & \\
\hline Anas spp. (Ducks) & $\mathrm{X}$ & $\mathrm{X}$ & $\mathrm{X}$ & $\mathrm{X}$ & $\mathrm{X}$ & $\mathrm{X}$ \\
\hline Sagittaria latifolia (Wapato) & $\mathrm{X}$ & $\mathrm{X}$ & & & $\mathrm{X}$ & $\mathrm{X}$ \\
\hline Camassia quamash (Camas) & & & & $\mathrm{X}$ & $\mathrm{X}$ & \\
\hline Spermophilus spp. (Squirrels) & & $\mathrm{X}$ & $\mathrm{X}$ & $\mathrm{X}$ & & \\
\hline Lepus spp. (Hares) & $\mathrm{X}$ & $\mathrm{X}$ & $\mathrm{X}$ & $\mathrm{X}$ & $\mathrm{X}$ & $\mathrm{X}$ \\
\hline Geomyidae (Gopher) & $\mathrm{X}$ & $\mathrm{X}$ & $\mathrm{X}$ & $\mathrm{X}$ & $\mathrm{X}$ & $\mathrm{X}$ \\
\hline Odocoileus spp. (Deer) & $\mathrm{X}$ & $\mathrm{X}$ & $\mathrm{X}$ & $\mathrm{X}$ & $\mathrm{X}$ & $\mathrm{X}$ \\
\hline $\begin{array}{l}\text { Oncorhynchus tshawytscha } \\
\text { (dry) (Chinook Salmon) }\end{array}$ & & $\mathrm{X}$ & $\mathrm{X}$ & & & \\
\hline $\begin{array}{l}\text { Oncorhynchus tshawytscha } \\
\text { (fresh) (Chinook Salmon) }\end{array}$ & & $\mathrm{X}$ & $\mathrm{X}$ & & & \\
\hline
\end{tabular}

In the vicinity of Willamette Falls, between early spring and early summer when the fish arrived at the falls, Chinook salmon would have been the highest ranked resource whether eaten fresh or dried (Table 7, Table 8). 
Table 7. Types and Post-Processing Return Rate of Resources near Willamette Falls, Averaged for Whole Year

\begin{tabular}{lc}
\hline \multicolumn{1}{c}{ Name } & Mean Value (kcal) \\
\hline Oncorhynchus tshawytscha (fresh) & 87441.37 \\
Oncorhynchus tshawytscha (dried) & 35635.87 \\
Odocoileus hemionus & 24710.5 \\
Geomyidae & 9881.5 \\
Lepus spp & 9391.5 \\
Spermophilus spp. & 5865.5 \\
Sagittaria latifolia & 3240 \\
Anas spp. & 2342 \\
Quercus spp. & 2075 \\
Camassia quamash & 2042 \\
Corylus spp & 492 \\
\hline
\end{tabular}

Table 8. Resource Rank in Bi-Monthly Segments at or near Willamette Falls

\begin{tabular}{|c|c|c|c|c|c|c|}
\hline Rank & $\begin{array}{l}\text { January/ } \\
\text { February }\end{array}$ & March/ April & May/June & July/August & $\begin{array}{l}\text { September/ } \\
\text { October }\end{array}$ & $\begin{array}{l}\text { November/ } \\
\text { December }\end{array}$ \\
\hline 1 & $\begin{array}{l}\text { Odocoileus } \\
\text { hemionus }\end{array}$ & $\begin{array}{l}\text { Oncorhynchus } \\
\text { tshawytscha } \\
\text { (fresh) }\end{array}$ & $\begin{array}{l}\text { Oncorhynchus } \\
\text { tshawytscha } \\
\text { (fresh) }\end{array}$ & $\begin{array}{l}\text { Odocoileus } \\
\text { hemionus }\end{array}$ & $\begin{array}{l}\text { Odocoileus } \\
\text { hemionus }\end{array}$ & $\begin{array}{l}\text { Odocoileus } \\
\text { hemionus }\end{array}$ \\
\hline 2 & Geomyidae & $\begin{array}{l}\text { Oncorhynchus } \\
\text { tshawytscha } \\
\text { (dry) } \\
\text { Odocoileus }\end{array}$ & $\begin{array}{l}\text { Oncorhynchus } \\
\text { tshawytscha } \\
\text { (dry) } \\
\text { Odocoileus }\end{array}$ & Geomyidae & Geomyidae & Geomyidae \\
\hline 3 & $\begin{array}{l}\text { Lepus spp. } \\
\text { Sagittaria }\end{array}$ & hemionus & hemionus & $\begin{array}{l}\text { Lepus spp. } \\
\text { Spermophilu }\end{array}$ & $\begin{array}{l}\text { Lepus spp. } \\
\text { Sagittaria }\end{array}$ & $\begin{array}{l}\text { Lepus spp. } \\
\text { Sagittaria }\end{array}$ \\
\hline 4 & latifolia & Geomyidae & Geomyidae & s spp. & latifolia & latifolia \\
\hline 5 & Anas spp. & $\begin{array}{l}\text { Lepus spp. } \\
\text { Spermophilus }\end{array}$ & $\begin{array}{l}\text { Lepus spp. } \\
\text { Spermophilus }\end{array}$ & Anas spp. & Anas spp. & Anas spp. \\
\hline 6 & & $\begin{array}{l}\text { spp. } \\
\text { Sagittaria }\end{array}$ & spp. & $\begin{array}{l}\text { Quercus spp/ } \\
\text { Camassia }\end{array}$ & $\begin{array}{l}\text { Quercus spp. } \\
\text { Camassia }\end{array}$ & \\
\hline 7 & & latifolia & Anas spp. & quamasl & quamash & \\
\hline 8 & & Anas spp. & & & Corylus spp. & \\
\hline
\end{tabular}

In periods when salmon was not available, deer and small mammals would have been the highest ranked resources. Camas achieves its highest rank $\left(7^{\text {th }}\right)$ during the period of September/October, while wapato achieves its highest rank $\left(4^{\text {th }}\right)$ during the periods of November/December and 
January/February. Small mammals and ducks are consistently a middle to upper-middle ranked resource throughout the year.

Above Willamette Falls, deer is the highest, and Chinook salmon is the second highest ranked resource in the region when seasonality is not considered (Table 9). Fresh salmon would have been the second highest ranked resource if seasonality is taken into account (Table 10). Dried salmon drops to the fifth highest ranked resource during the period when salmon would have been exploited. Small mammals and ducks are consistently middle to upper-middle ranked throughout the year.

Table 9. Types and Post-Processing Return Rate of Resources above Willamette Falls

\begin{tabular}{lc}
\hline \multicolumn{1}{c}{ Name } & Mean Value (Kcal) \\
\hline Odocoileus hemionus & 24710.5 \\
Oncorhynchus tshawytscha (fresh) & 15457.5 \\
Geomyidae & 9881.5 \\
Lepus spp & 9391.5 \\
Oncorhynchus tshawytscha (dried) & 8583.5 \\
Spermophilus spp. & 5865.5 \\
Sagittaria latifolia & 3240 \\
Anas spp. & 2342 \\
Quercus spp. & 2075 \\
Camassia quamash & 2042 \\
Corylus spp. & 492 \\
\hline
\end{tabular}


Table 10. Resource Rank in Bi-Monthly Segments above Willamette Falls

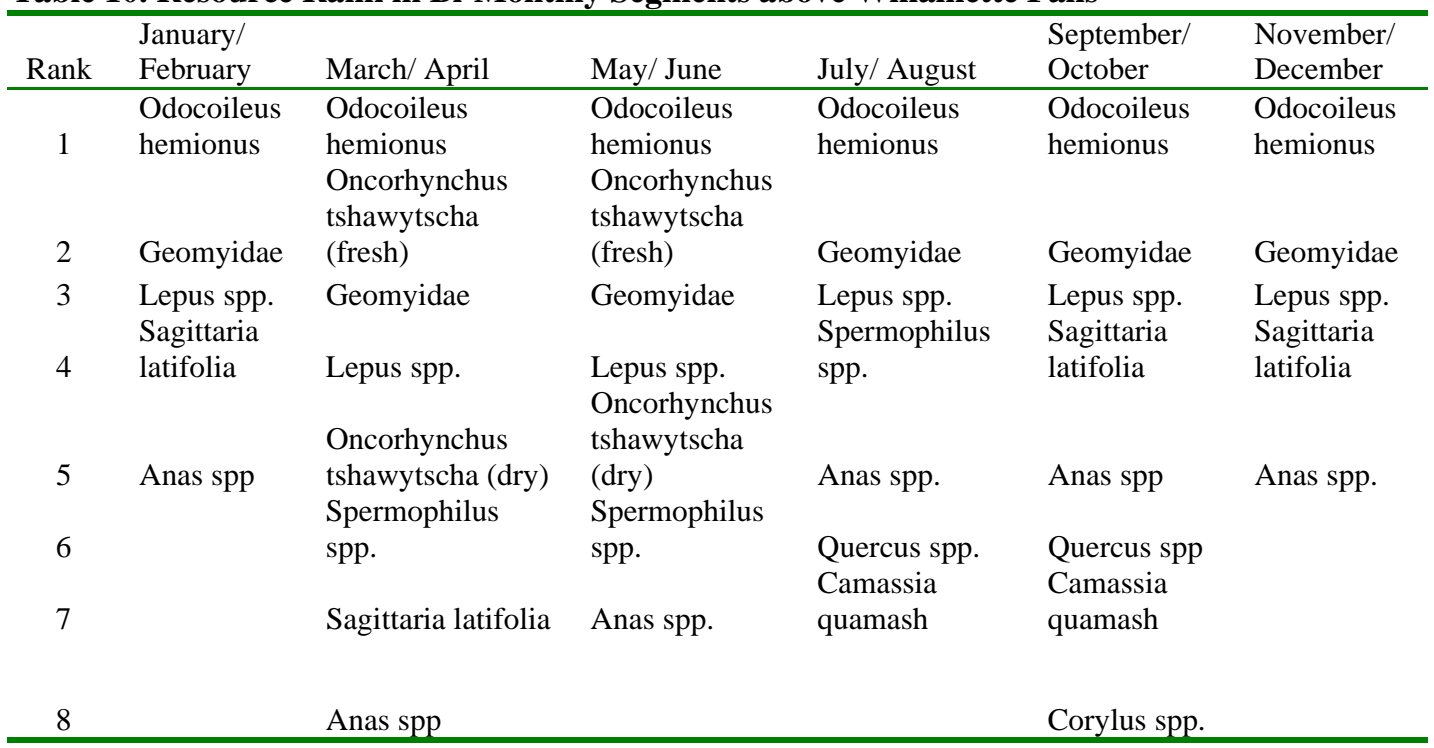

\section{Discussion}

Based on the results of diet breadth analysis, spring Chinook salmon are the highest ranked resource at Willamette Falls, and the second highest ranked resource above Willamette Falls, when they are captured and consumed fresh in the late spring and early summer. Salmon's availability does not coincide with camas availability, and may intermittently coincide with wapato availability.

Plant foods tend to be low ranked resources for all seasons, which is expected. In addition to their low rank, plant foods also tend to be highly seasonal in availability.

While Chinook salmon are highly ranked resources throughout the Willamette Valley, and the highest ranked resource at Willamette Falls, deer are the highest ranked resource in the Willamette Valley, above Willamette 
Falls, which represents much of the region. In addition, while salmon would have been highly ranked when available, their availability was patchy both in time and space. Deer, by comparison, would have been available year-round. While intriguing, this modeling effort has limitations. I was able to estimate post-processing return data for nine of 16 resources in the Willamette Valley. Based on this incomplete sample, salmon are highly ranked when available. Their availability, however, is limited to specific locations at specific times. Plants share this constraint, but may have the advantage of being easier to process for long-term storage. Deer, ducks, and small mammals were available year-round, and in all areas above Willamette falls, deer are the highest ranked resource throughout the year. The combination of limited availability in time and space and the presence of other highly ranked resources year round may affect how the native peoples of the Willamette Valley viewed salmon as a resource. 
Chapter 5. Discussion and Conclusions

The goal of my thesis was to determine whether the regional archaeological record is adequate for assessing salmon use in the Willamette drainage, and to explore whether salmon would have been a viable resource for exploitation. To do this, I synthesized aspects of the regional archaeological record to determine whether salmon were used, and if the regional faunal sample was sufficient to rule out their use if salmon remains were not found. In addition, the diet breadth model was used to test whether salmon exploitation would have been a viable option for the people of the Willamette Valley given the availability of a variety of resources.

My work demonstrates there are very few sites with identified faunal material, and only one site (35-LIN-468) with a variety of animal taxa present resulting from human exploitation. Faunal remains are extremely rare in Valley sites. Thus the scarcity of fish remains could simply be a function of the overall scarcity of bone, rather than signify anything about past human activities. The Willamette Valley zooarchaeological record inadequately addresses whether salmon was used by the people of the Willamette Valley.

Blood residue analysis from five sites yielded positive results for trout residue. However, there is clearly still debate about the validity of blood 
residue analysis. Therefore, these data may indicate that trout or salmon were collected above Willamette Falls, as well as provide a harvest location, but until there is greater agreement about the validity of blood residue analysis, it cannot be used as a strong line of evidence.

\section{Diet Breadth}

While the results of my diet breadth analysis show that salmon would have been a very highly ranked resource in the region, it is important to recognize that this model is based on assumptions about gear and harvesting rates from areas outside of the Willamette Valley, including the Snake River and the Western Great Basin (Plew 1983, Lindström 1996). Factors such as salmon run size, ease of capture, and methods used for capture, all of which affect post-processing return rate, may have varied from that which occurred in the Willamette River. As a result, the reported post-processing return rate is a rough approximation of what the caloric value of salmon was in this region. Additionally, the breadth of resources used for this analysis was limited both in the detail and variety of the ethnographic and archaeological datasets, as well as by the limited amount of data about resources that are known to have been used in the region, and will be discussed below. In addition, if more plant resources were used than reported, or if the values for known resources were included in the model (eg. berries, tarweed), then it is likely that the mean caloric value for the full range of resources would decrease. Darby (1996) argues against the assumption that all foods are ranked by the same currency. 
Salmon provide a large amount of protein, but few carbohydrates. Geophytes, by comparison, provide large amounts of carbohydrates but little protein. It is likely that lower ranked resources would be selected for their carbohydrate value rather than their caloric value alone.

I could not find post-processing return rate information for seven resources, including elk, black bear, lamprey, tarweed, Rubus and Vaccinium berries, and caterpillars. While this does not necessarily negate the value of the model, which is to demonstrate that salmon were highly ranked resources, it does mean their relative rank could have been lower than what was observed in the model. For example, it is likely that, above Willamette Falls, elk would have been ranked higher than salmon given their great body size, and the high cost of salmon procurement.

In order to get a more concrete idea of what salmon's relative rank would have been in the Willamette Valley, it is necessary to consider the environmental factors that may have affected salmon availability. Schalk (1986:13) argues that seasonal variations in river height and waterfall volume affected the vertical distance that the fish need to jump to ascend the falls. During periods where a high volume of water is expelled over the waterfall and the river is high, the vertical distance may be half that of the falls during the dry season, which extends between July and October (Zenk 1976). As a result, fish may only have been able to ascend the falls in the spring and summer. This observation is supported by Fulton (1968:18), who notes that Willamette 
Falls "probably always blocked fall chinook salmon." The combination of a single salmon season, and potentially unpredictable falls passage may have had two effects on salmon abundance and, in turn, human decision making about resource selection. First, salmon may not have been a predictable enough resource to have been sought after; geophytes, on the other hand met these conditions. Second, the number of salmon that could ascend the falls may have been too low to exploit in any meaningful number, which is the condition for intensifying gephyte exploitation in Thoms' (1989) model.

Once spring Chinook salmon ascend the falls, they are not evenly distributed throughout the Willamette River and its tributaries. Therefore, even if, as Fulton notes $(1968,1970)$, the Willamette has "substantial" stocks of salmon during the spring run, these runs would be limited to the mainstem Willamette River and its eastern tributaries.

Another factor that would have affected salmon's ranking relative to other resources is storage potential. Schalk (1986:13) notes that fall salmon are better suited for storage purposes than the spring run salmon since the latter have high oil content, and their arrival precedes the hottest months of the year, making drying and storage difficult. In the larger Pacific Northwest region, the fall run was generally preferred for drying and smoking (Schalk 1986:13). Following Schalk's reasoning based on ethnographic analysis, unlike other peoples of the Pacific Coast and the Columbia River who caught, dried, and stored salmon for year-round consumption, the native peoples of 
the Willamette Valley would have relied on spring salmon as a fresh resource, not for preservation.

Considering storage and transportation, the Kalapuyans used baskets and had canoes (Zenk 1990) and stored camas and wapato. Therefore, technologically at least, the Native People of the Willamette Valley had the capacity to transport and store large quantities of salmon. Kaplan and Hill (2008: 186) argue that when foragers are collecting resources from a patch, and transporting them back to their place of residence, they should collect resources that yield the highest amount of calories per basket load. If this argument is applied to salmon vs. any plant resources, salmon should be selected. However, the only plant resource collection activity that may have occurred during the same period as the spring run of salmon would have been wapato, which grows in lakes and rivers, one of which is the same environment where salmon could be found. Considering transportation distance, Thoms (1989:302) reports that the Native people of the Willamette Valley wintered on relatively high ground, but moved closer to the river during the spring and summer. This suggests that the people of the Willamette Valley would not have had to transport salmon far by land.

Overall, Fulton's $(1968,1970)$ data suggests that the Willamette River ecosystem had the capacity to support "substantial" amounts of salmon above the falls, which means that there was no environmental reason that the spring salmon run was not exploited. On the other hand, stream discharge and size 
affected salmon distribution above Willamette Falls. This means that the smaller rivers with low discharges (e.g. Molalla and Tualatin) would have had smaller runs than larger rivers (e.g. North and South Santiam). This suggests that while salmon would have been abundant where they were available, their availability was likely patchy.

In sum, even if salmon were not as abundant in the Willamette Valley as in other areas of the Pacific Northwest, or if the time of their arrival did not coincide with the optimal time for fish processing and storage, fresh salmon was a very highly ranked resource that could be exploited predictably. Additionally, spring Chinook salmon would have been available just after wapato harvest between fall and late spring, and long before the camas harvest in late summer and fall, which suggests that it would not have conflicted with collection of resources that are known to have been extensively used.

\section{Conclusion}

My thesis challenges a commonly held stereotype that the Indigenous people of the Willamette Valley were strictly root eaters, and the basis for this claim, that salmon were not part of Native subsistence. First, given the incomplete nature of the ethnohistoric record, very little can be said about expected cultural behaviors, such as salmon consumption, that appear to be absent in the Willamette Valley. Second, since the faunal assemblage is so small in the Willamette Valley, zooarchaeological data are simply inadequate 
for studying the relationship between prehistoric peoples and their animal resources. Third, optimal foraging modeling suggests that salmon is one of the higher ranked resources available to the Native People of the Willamette Valley. The Willamette River sustained substantial stocks of salmon, whose availability coincides with a season when other known intensively used resources were not being harvested. As a result, there is no ecological reason that salmon would not have been exploited by the Native People of the Willamette Valley.

In order to test the expectations posed by this model, future work will need to integrate other types of archaeological remains (eg. fishing-related tools, residue analysis), since faunal remains are rare. Residue analysis has potential, but there is still debate about the validity of its results. These concerns need to be addressed prior to wide scale implementation. 


\section{References}

Aikens, C. Melvin

1993 Archaeology in Oregon. U.S. Department of the Interior. Bureau of Land Management. Portland, Oregon.

Alt, David and Donald W. Hyndman

1981 Roadside Geology of Oregon. Mountain Press Publishing Company, Missoula Montana.

Ames, Kenneth M.

1994 The Northwest Coast: Complex Hunter-Gatherers, Ecology, and Social Evolution. Annual Reviews in Anthropology 23:209-229.

2004 Intensification of Food Production on the Northwest Coast and Elsewhere. In Keeping it Living: Traditions of Plant Use and Cultivation on the Northest Coast of North America. D.a.N.J.T. Deur, ed. Seattle: University of Washington Press.

Ames, Kenneth M., and Herbert D.G. Maschner 1999 Peoples of the Northwest Coast: Their Archaeology and Prehistory. London: Thames and Hudson.

Binford, Lewis R. 1980 Willow Smoke and Dogs's Tails: Hunter-Gatherer Settlement Systems and Archaeological Site Formation. American Antiquity 45(1):4-20.

Bowers, Peter M. and Madonna L. Moss

2001 People and Culture in Northern North American: Essays in Honor of R. Dale Guthrie. Ed by Craig Gerlarch and Maribeth S. Murrary. BAR International Series 994.

Boyd, Robert T.

1975 Another Look at the "Fever and Ague" of Western Oregon.

Ethnohistory, Vol. 22, No. 2

Broughton, Jack M. and James F. O'Connell 1999 On Evolutionary Ecology, Selectionist Archaeology, and Behavioral Archaeology. American Antiquity 64(1):153-165.

Bunting, Robert 
1995 The Environment and Settler Society in Western Oregon. The Pacific Historical Review 64(3):413-432.

Butler, V.L.

1993 Natural vs. Cultural Salmonid Remains: Origin of the Dalles Roadcut Bones, Columbia River, Oregon. Journal of Archaeological Science 20:1-24.

Butler, V.L., and Sarah K. Campbell

2004 Resource Intensification and Resource Depression in the Pacific Northwest of North America: A Zooarchaeological Review. Journal of World Prehistory 18(4).

Butler, V.L., and J.C. Chatters

1994 The Role of Bone Density in Structuring Prehistoric Salmon Bone Assembalges. Journal of Archaeological Science 21:413-424.

Butler, Virginia L., and Jim E. O'Connor 20049000 Years of Salmon Fishing on the Columbia River, North America. Quaternary Research 62:1-8.

Cannon, Michael D.

1999 A Mathematical Model of the Effects of Screen Size on

Zooarchaeological Relative Abundance Measures. Journal of Archaeological Science 26:205-214.

Casteel. R. W. 1972 Some Biases in the Recovery of Archaeological Faunal Remains. Proceedings of the Prehistoric Society 36,382-388.

Cochrane, Grant W.G.

2003 Artefact Attribute Richness and Sample Size Adequacy. Journal of Archaeological Science 30:837-848.

Cressman, L.S., Cole, D. L., Davis, W.A., Newman, T.M., and Scheans, D.J. 1960 Cultural Sequences at the Dalles, Oregon: A Contribution to Pacific Northwest Prehistory, Transactions of the American Philosophical Society 50(10):3-108

Coues, Elliot (editor) 1897 New Light on the Early History of the Greater Northwest, the Manuscript Journals of Alexander Henry and David Thompson. New York: Harper

Craig, J.A. and R. L. Hacker 
1940 The History and Development of the Fisheries of the Columbia River. Bulletin of the Bureau of Fisheries 32.

Darby, Melissa Cole

1996 Wapato for the People: An Ecological Approach to Understanding the Native American use of Sagittaria latifolia on the Lower Columbia River, Portland State University.

Dunnell, Robert C.

1989 Methodological Impacts of Catastrophic Depopulation on American Archaeology and Ethonology. In Columbian Consequences, Vol.3: The Spanish Borderlands in Pan-American Perspective. D.H. Thomas, ed. pp. 561580. Washignton D.C.: Smithsonian Institute Press.

Eder, Tamara 2002 Mammals of Washington and Oregon. Auburn: Lone Pine.

Franklin, Jerry F., and C.T. Dyrness

1979 Natural Vegitation of Oregon and Wasington. Corvallis: Oregon State University Press.

Fiedel, Stuart J.

1996 Blood from Stones? Some Methodological and Interpretive Problems in Blood Residue Analysis. Journal of Archaeological Science 23:139-147.

Fulton, Leonard A.

1968 Spawning Areas and Abundance of Chinook Salmon (Oncorhynchus tshawytscha) in The Columbia River Basin-Past and Present. United States Department of Commerece.

1970 Spawning Areas and Abundance of Steelhead Trout and Coho, Sockeye, and Chum Salmon in the Columbia River Basin- Past and Present. United States Department of Commerece.

Galbreath, James L.

1965 The Timing of Willamette River Spring Chinook Salmon Through the Lower Columbia River. Oregon Fish Commission Research Briefs 11(1):29-41

Galbraith, William A. and E. William Anderson 1991 Grazing History of the Northwest. Rangelands 13(5):213-218.

Glenn, Jerry Lee 
1965 Late Quaternary Sedimentation and Geologic History of the North Willamette Valley, Oregon. Dissertation Oregon State University

Grayson. D. K, $1984 \quad$ Quantitative Zooarchaeology: Topics in the Analysis of Archaeological Faunas. New York: Academic Press.

Kaplan, Hillard, and Kim Hill 2008 The Evolutionary Ecology of Food Acquisition. In Evolutionary Ecology and Human Behavior. E.A.S.a.B. Winterhalder, ed, Vol. 3. New Brunswich: Transaction Publishers.

Kelly, Robert 1995 The Foraging Spectrum. Washington: Smithsonian Institute.

Kramer, Stephenie

2000 Camas Bulbs, The Kalapuya, and Gender: Exploring Evidence of Plant Food Intensification in the WIllamette Valley in Oregon, University of Oregon.

Kroeber, A.L.

1939 Cultural and Natural Areas of Native North America. University of California Publications in American Archaeology and Ethnology, 38. Berkley.

Jacobs, Melville

1945 Kalapuya Texts, Part 1: Santiam Kalapuya Ethnologic Texts. University of Washington Publications in Anthropology. Vol. 11, Seattle, WA.

Jones, Kevin T., and David B. Madsen

1989 Calculating the Cost of Resource Transportation: A Great Basin

Example. Current Anthropology 30(4):529-534.

Laughlin, William S.

1943 Notes on the Archaeology of the Yamhill River, Willamette Valley, Oregon. American Antiquity 9(2):220-229.

Lindström, Susan

1996 Great Basin Fisherfolk: Optimal Diet Breadth Modeling the Trickee

River Aboriginal Subsistence Fishery. In Prehistoric Hunter-Gatherre Fishing Strategies. M.G. Plew, ed. Boise: Boise State University.

Lubinski, Patrick M.

1996 Fish Heads, Fish Heads: An Experiment on Differential Bone

Preservation in Salmonid Head. Journal of Archaeological Science 23:175-181 
Lyman, R. Lee

1987 Appendix D: Elk Creek Zooarchaeology. In Pettigrew, Richard M. and Clayton G. Lebow eds, Data Recovery at Sites 35JA27, 35JA59, and 35JA100, Elk Creek Lake Project, Jackson County, Oregon, Volume 1. Infotec Research Incorporated.

1994 Vertebrate Taphonomy. Cambridge University Press. Cambridge, United Kingdom.

1995 Determining When Rare (Zoo-)Archaeological Phenomena Are Truly Absent. Journal of Archaeological Method and Theory. Vol. 2, No. 4, 1995

Lyman, R. Lee, and Kenneth M. Ames

2007 On the use of Species-area Curves to Detect the Effects of Sampling Size. Journal of Archaeological Science 34:1985-1990.

Lyman, R. Lee and Michael J. O'Brien

2001 The Direct Historical Approach, Analogical Reasoning, and Theory in Americanist Archaelogy. Journal of Archaeological Method and Theory 8(4):303-342.

Madsen, David B. and James E. Kirkman 1988 Hunting Hoppers. American Antiquity 53(3):593-604.

Matson, R.G.

1992 The Evolution of Northwest Coast Subsistence. In Croes, D.L., Hawkins, R.A., and Isaac, B.L. (eds.). Long-term Subsistence Changes in Prehistoric North America, Research in Economic Anthropology. JAI, Greenwich

Matson, R.G., and Gary Coupland

1995 The prehistory of the Northwest Coast San Diego: Academic Press

McKinney, F. Ann

1984 Kalapuyan Subsistence: Reexamining the Willamette Falls Salmon Barrier. Northwest Anthropological Research Notes 18:23-33.

Metcalfe, Duncan, and K. Renee Barlow 1992 A Model for Exploring the Optimal Trade off between Field Processing and Transport. American Anthropologist 94(2):340-356. 
Nagaoka, Lisa

2002 The Effects of Resource Depression on Foraging Efficiency, Diet

Breadth and Patch Use in Southern New Zealand. Journal of Anthropological Archaeology: 21. Pp. 419-442

O'Connor, J.E., Sarna-Wojcick, A., Woznikak, K.C., Polette, D.J., Fleck, R.J. 2001 Origin, Extent, and Thickness of Quaternary Geologic Units in the Willamette Valley, Oregon; U.S. Geological Survey, Professional Paper 1620, $51 \mathrm{p}$

Peacock, S.L.

1998 Putting Down Roots: The Emergence of Wild Plant Food Production on the Canadian Plateau. Dissertation, University of Victoria.

Peterson, C.D., and Phipps, J.B., 1992 Holocene sedimentary framework of Grays Harbor Basin, Washington, USA, in Fletcher, C.H. and Wehmiller, J.F., eds., Quaternary Coasts of the United States: Marine and Lacustrine Systems, SEPM Special Publication No. 48, p. $273-285$.

Pettigrew, Richard M.

1990 Prehistory of the Lower Columbia and Willamette Valley. In Handbook of North American Indians. W.C. Sturtevant, ed, Vol. 7. Seattle: Smithsonian.

Plew, Mark G.

1983 Implications of Nutritional Potential of Anadromous Fish Resources of the Western Snake River Plain. Journal of California and Great Basin Anthropology 5(1 and 2):58-65.

Pojar, Jim, and Andy MacKinnon

1994 Plants of the Pacific Northwest Coast. Vancouver B.C.: Lone Pine.

Quinn, Thomas P.

2005 The Behavior and Ecology of Pacific Salmon and Trout. Seattle:

University of Washington Press.

Reidhead, Vann A.

1980 The Economics of Subsistence Change: Test of an Optimization Model. In Modeling Change in Prehistoric Subsistence Economies. T.K. Earle and A.L. Christenson, ed. Pp. 141-186. New York: Academic Press.

Reuther, Joshua D., et al. 
2006 The use of an improved pRIA technique in the identification of protein residues. Journal of Archaeological Science 33(4):531-537.

Schalk, Randall F.

1981 Land Use and Organizational Complexity among Foragers of Northwestern North America. In Affluent Foragers, Pacific Coast East and West. D.H.T. S. Koyama, ed, Vol. 9. Osaka: Senri Ecological Studies.

1986 Estimating Salmon and Steelhead Usage in the Columbia Basin Before 1850: The Anthropological Perspective. Northwest Environmental Journal 2(2):1-29.

Schiffer, Michael B.

1983 Toward the Identification of Formation Processes. American Antiquity 48(4):675-706.

1996 Formation Processes of the Archaeological Record. Salt Lake City: University of Utah Press.

Simms, Steven R.

1985 Acquisition Cost and Nutritional Data on Great Basin Resources. Journal of California and Great Basin Anthropology:117-126.

Smith, Eric A., and B. Winterhalder 2003 Human behavioral ecology. In Encyclopedia of Cognitive Science, Volume 2, edited by Lynn Nadel, pp. 377-385. London: Nature Publishing Group.

Spores, Ronald 1993 Too Small a Place: The Removal of the Willamette Valley Indians, 1850-1856. American Indian Quarterly 17(2):170-191.

Stein, Julie K.

1992 Interpreting the Stratigraphy of Northwest Shell Middens. In

Deciphering Shell Middens. J.K. Stein, ed. Pp. 26-34. Seattle: Academic Press.

Stewart, Julian $\mathrm{H}$.

1942 The Direct Historical Approach to Archaeology. American Antiquity:7(4). pp. 337-343.

Sutton, Mark Q. and E.N. Anderson

2004 Introduction to Cultural Ecology. Walnut Creek: AltaMira Press. 
Thomas, D.H.

1969 Great Basin Hunting Patterns: A Quantitative method for Treating Faunal Remains. American Antiquity 34(3).

Thoms, Alston Vern

1989 The Northern Roots of Hunter-Gatherer Intensificaiton: Camas and the Pacific Northwest, Washington State University.

Trigger, Bruce G.

1966 Comments on Estimating Aboriginal American Populations (Dobyns and Thompson). Current Anthropology 7: 439-440

1996 A History of Archaeological Thought. Cambridge University Press. Cambridge.

USDA

1999 USDA Nutrient Database for Standard Reference, Release 12 (March 1998). All other data from the USDA Nutrient Database for Standard Reference, Release 13

USGS 2008

2008 Holocene Evolution, OFR 01-076. http://pubs.usgs.gov/of/2001/of01076/HTMLDOCS/GEOLOGY.HTM\#evolution.

Vale, Deborah and Robert H. Gargett

2002 Size Matters: 3-mm Sieves do not Increase Richness in a Fishbone Assemblage from Arrawarra I, an Aboriginal Australian Shell Midden on the Mid-North Coast of New South Wales, Australia. Journal of Archaeological Science 29:57-63.

Van der Leeuw, Sander and Charles L. Redman 2002 Placing Archaeology at the Center of Socio-Natural Studies. American Antiquity 67(4):597-605.

Wallick, Jennifer Rose, Gordon E. Grant, Stephen T. Lancaster, John P. Bolte, and Roger P. Denlinger

2007 Patterns and Controls on Historical Channel Change in the Willamette River, Oregon, USA. In Large Rivers: Geomorphology and Management, ED A. Gupta. John Wiley and Sons, Ltd.

Wolff, R.G. 
1975 Sampling and Sample Size in Ecological Analysis of Fossil Mammals. Paleobiology 1:195-204.

White, John R.

1979 A Chronology of Upper Willamette Valley, Oregon, Prehistory. American Antiquity 44(3):556-568.

Wilkes, Charles

1845 Narrative of the United States Exploring Expedition during the Years of 1838, 1839, 1840, 1841, and 1842. Philidelphia: Lea and Blanchard.

Williams, Shirley Barr 1994 Results of Blood Residue Analysis for Data Recovery Phase Excavations, Northwest Pipeline Corporation's System Expansion Phase I Oregon. In Northwest Pipeline Corporation System Expansion Phase 1: Phase 3 - Data Recovery and Site Treatment Reports for Oregon Segments. Volume $\checkmark$, Part 1, Fagan et. al.

Winterhalder, Bruce

2002 Behavioral and Other Human Ecologies: Critique, Response and Progress through Criticism. Journal of Ecological Anthropology 6:4-23.

Wolff, R.G.

1975 Sampling and Sample Size in Ecological Analysis of Fossil Mammals. Paleobiology 1:195-204.

Wydoski, Richard S. and Richard R. Whitney 2003 Inland Fishes of Washington. University of Washington Press, Seattle, Washington.

Zar, J.H.

1984 Biostatistical Analysis, 2nd edn. Englewood Cliffs: Prentice-Hall International, Inc

Zenk, Henry B.

1976 Contributions to Tualatin Ethnography: Subsistence and Ethnobiology. MA Thesis, Portland Sate University, Portland, Oregon

1990 Kalapuyans. In Handbook of North American Indians. W.C. Sturtevant, ed, Vol. 7. Seattle: Smithsonian. 
2008 Notes on Native American Place-names of the Willamette Valley Region. Oregon Historical Quarterly 109(1):6-33.

Zohar, Irit and Miriam Belmaker

2005 Size Does Matter: Methodological Comments on Sieve Size and Species Richness in Fishbone Assemblages. Journal of Archaeological Science 32:635-641. 
Appendix A. Summary of all Cultural Resource Reports with Excavation within Willamette Valley, as of June 2009 


\begin{tabular}{|c|c|c|c|c|c|c|c|c|c|c|c|c|c|c|c|c|c|}
\hline $\begin{array}{l}\text { SHPO } \\
\text { Bib \# }\end{array}$ & Site \# & $\begin{array}{c}\text { Site } \\
\text { Name }\end{array}$ & $\begin{array}{c}\text { Locatio } \\
\text { n }\end{array}$ & Author & Year & Page \# & $\begin{array}{c}\text { Data } \\
\text { Collecti } \\
\text { on } \\
\text { Method }\end{array}$ & $\begin{array}{l}\text { Mesh } \\
\text { Size }\end{array}$ & $\begin{array}{c}\text { Unit of } \\
\text { Measure }\end{array}$ & $\begin{array}{c}\text { Fau } \\
\text { nal } \\
\text { tabl } \\
\text { e }\end{array}$ & $\begin{array}{c}\text { Faun } \\
\text { al } \\
\text { Rem } \\
\text { ains }\end{array}$ & $\begin{array}{l}\text { Salmo } \\
\text { n } \\
\text { Identi } \\
\text { fied }\end{array}$ & $\begin{array}{c}\text { Botan } \\
\text { ical } \\
\text { Rema } \\
\text { ins }\end{array}$ & $\begin{array}{c}\text { Radiocarbon } \\
\text { Dates }\end{array}$ & $\begin{array}{c}\text { Fish } \\
\text { ing } \\
\text { Gea } \\
r\end{array}$ & $\begin{array}{l}\text { Surfac } \\
\text { e Area } \\
\text { (square } \\
\text { meters) }\end{array}$ & $\begin{array}{c}\text { Volum } \\
\text { e } \\
\text { (cubic } \\
\text { meters) }\end{array}$ \\
\hline 8970 & 18-03-186 & - & $\begin{array}{c}\text { S. } \\
\text { Santia } \\
\text { m } \\
\text { S. } \\
\text { Santia }\end{array}$ & Cole & 1987 & $5-18$ & $\begin{array}{c}\text { Square } \\
\text { test } \\
\text { units } \\
\text { and } \\
\text { Excava } \\
\text { tion } \\
\text { Square } \\
\text { test }\end{array}$ & $1 / 4^{\prime \prime}$ & Unlisted & No & No & No & No & No & No & .5 & .2 \\
\hline 8970 & 18-03-187 & - & $\begin{array}{c}\mathrm{m} \\
\mathrm{S} . \\
\mathrm{Santia}\end{array}$ & Cole & 1987 & $5-18$ & $\begin{array}{l}\text { units } \\
\text { Square }\end{array}$ & $1 / 4 "$ & Unlisted & No & No & No & No & No & No & 1.75 & .875 \\
\hline 8970 & $18-03-188$ & - & $\begin{array}{l}\mathrm{m} \\
\mathrm{S} .\end{array}$ & Cole & 1987 & $5-18$ & $\begin{array}{c}\text { units } \\
\text { Square }\end{array}$ & $1 / 4 "$ & Unlisted & No & No & No & No & No & No & 1 & .4 \\
\hline 8970 & 18-03-189 & - & $\begin{array}{c}\text { Santia } \\
\text { m } \\
\text { S. }\end{array}$ & Cole & 1987 & $5-18$ & $\begin{array}{l}\text { test } \\
\text { units } \\
\text { Square }\end{array}$ & $1 / 4^{\prime \prime}$ & Unlisted & No & No & No & No & No & No & 1 & .6 \\
\hline 8970 & $18-03-190$ & - & $\begin{array}{c}\text { Santia } \\
\text { m } \\
\text { S. } \\
\text { Santia }\end{array}$ & Cole & 1987 & $5-18$ & $\begin{array}{c}\text { test } \\
\text { units } \\
\text { Square } \\
\text { test }\end{array}$ & $1 / 4 "$ & Unlisted & No & No & No & No & No & No & 2.75 & 1.65 \\
\hline 8970 & $\begin{array}{c}\text { 18-03-191 } \\
\text { 25-LA- } \\
\text { 1228 }\end{array}$ & - & $\begin{array}{l}\text { Coast } \\
\text { Fork }\end{array}$ & Cole & 1987 & $9,13-17$ & $\begin{array}{c}\text { units } \\
\text { Test } \\
\text { Pits } \\
\text { (50x50 }\end{array}$ & $1 / 4 "$ & Unlisted & No & No & No & No & No & No & 1 & .5 \\
\hline 12825 & 35-BE-10 & - & $\begin{array}{l}\text { Upper } \\
\text { Willa } \\
\text { mette }\end{array}$ & Havercroft & 1985 & $\begin{array}{c}\text { 74-77, } 100- \\
111\end{array}$ & $\begin{array}{c}\text { Excava } \\
\text { tion }\end{array}$ & $1 / 4 "$ & Count & Yes & Yes & No & No & Yes & No & 10 & $\begin{array}{l}\text { Unabl } \\
\text { e to } \\
\text { Deter } \\
\text { mine }\end{array}$ \\
\hline 12825 & 35-BE-37 & - & $\begin{array}{l}\text { Upper } \\
\text { Willa } \\
\text { mette }\end{array}$ & Havercroft & 1985 & $\begin{array}{c}\text { 74-77, 82- } \\
99\end{array}$ & $\begin{array}{c}\text { Excava } \\
\text { tion }\end{array}$ & $1 / 4^{\prime \prime}$ & Count & Yes & Yes & No & No & No & No & 28 & $\begin{array}{l}\text { Unabl } \\
\text { e to } \\
\text { deter } \\
\text { mine } \\
\text { Unabl }\end{array}$ \\
\hline $\begin{array}{l}12825 \\
15904\end{array}$ & 35-BE-39 & - & $\begin{array}{l}\text { Upper } \\
\text { Willa } \\
\text { mette } \\
\text { Upper }\end{array}$ & Havercroft & 1985 & $\begin{array}{c}74-77,112- \\
124\end{array}$ & $\begin{array}{c}\text { Excava } \\
\text { tion } \\
\text { Shovel }\end{array}$ & $1 / 4 "$ & Count & Yes & Yes & No & No & No & No & 12 & $\begin{array}{l}\text { e to } \\
\text { Deter } \\
\text { mine }\end{array}$ \\
\hline & 35-BE-51 & - & Willa & Rogers & 1996 & $9-21$ & Probes & $1 / 8^{\prime \prime}$ & Unlisted & No & No & No & No & No & No & 4.75 & 2.37 \\
\hline
\end{tabular}




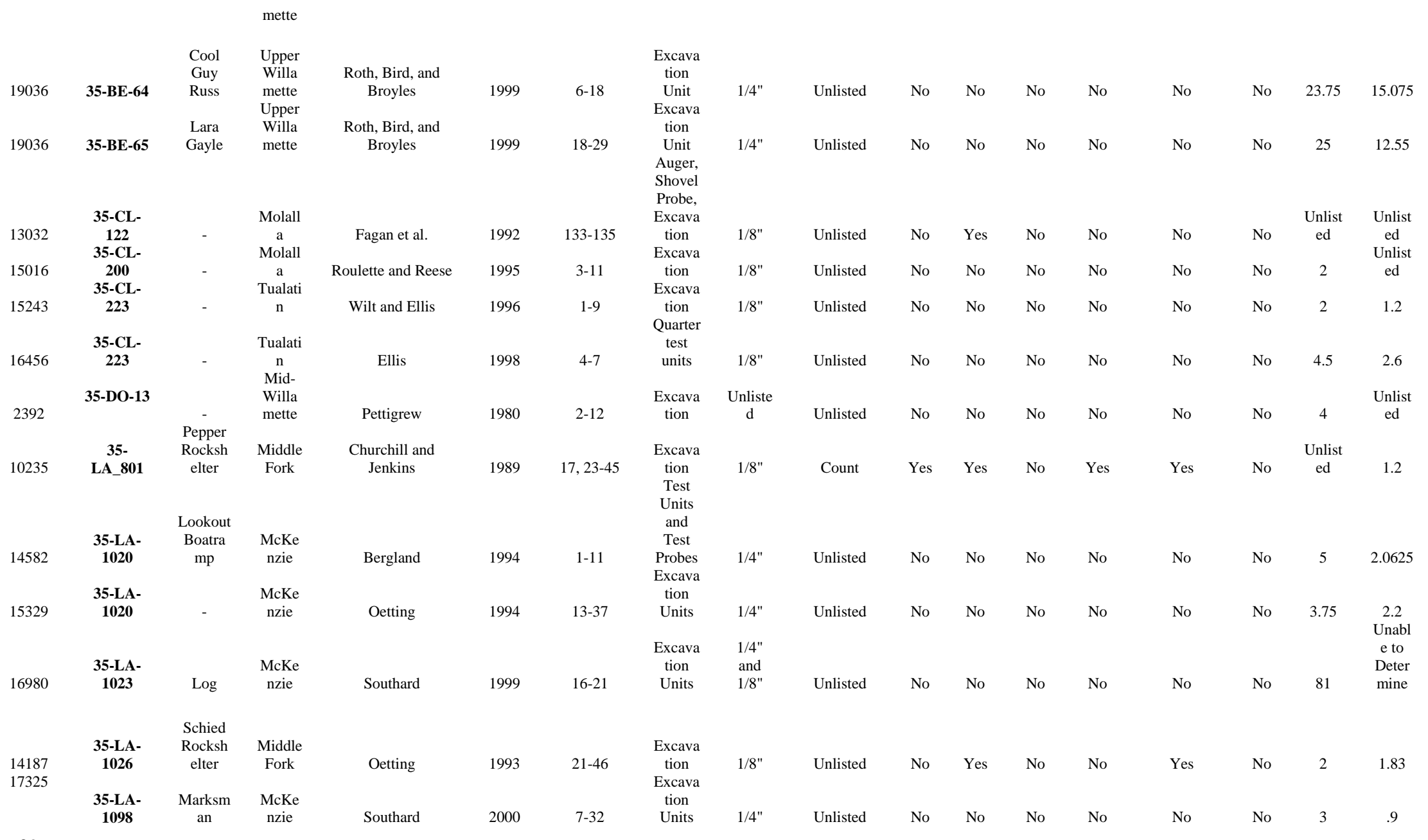




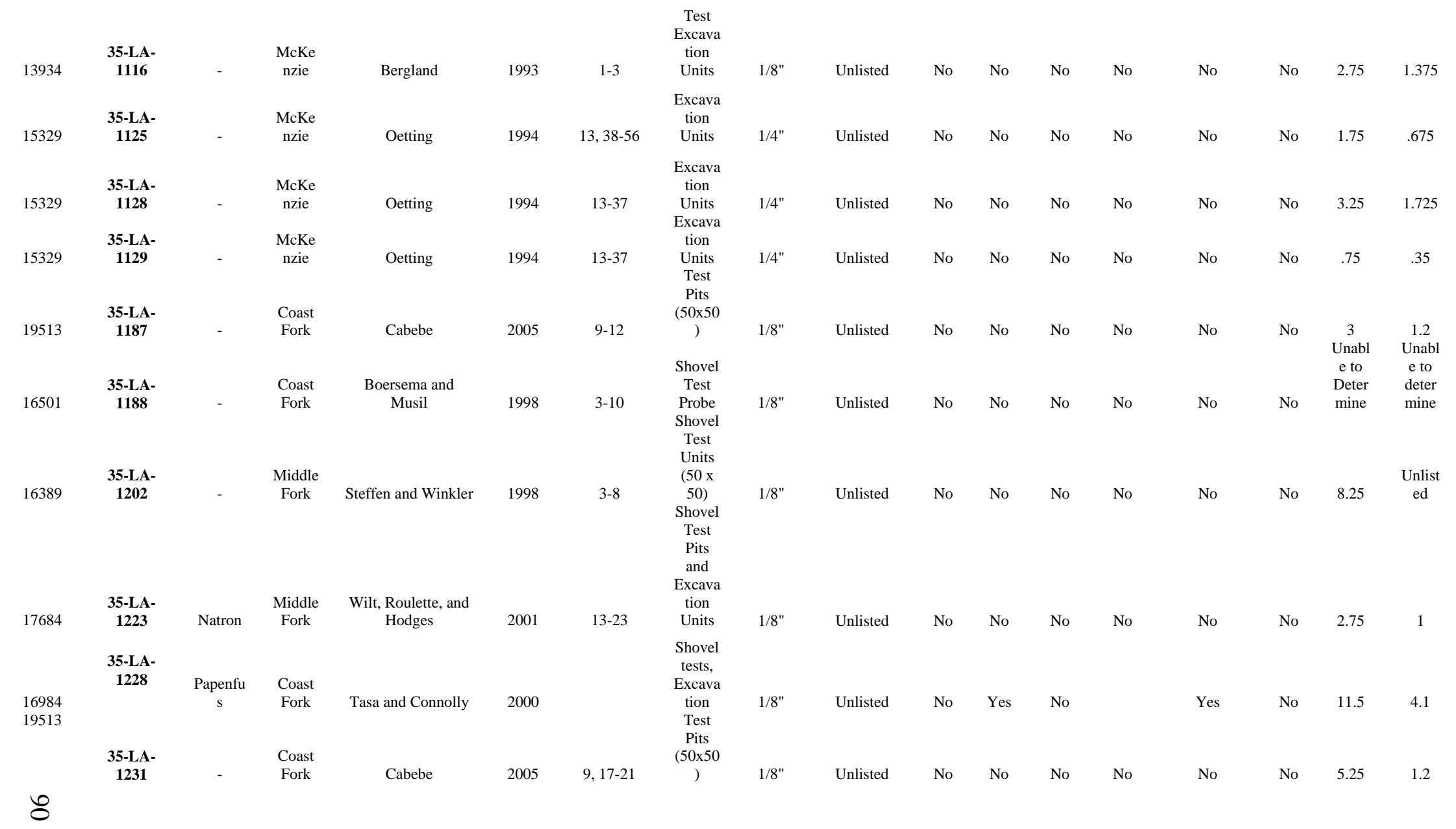




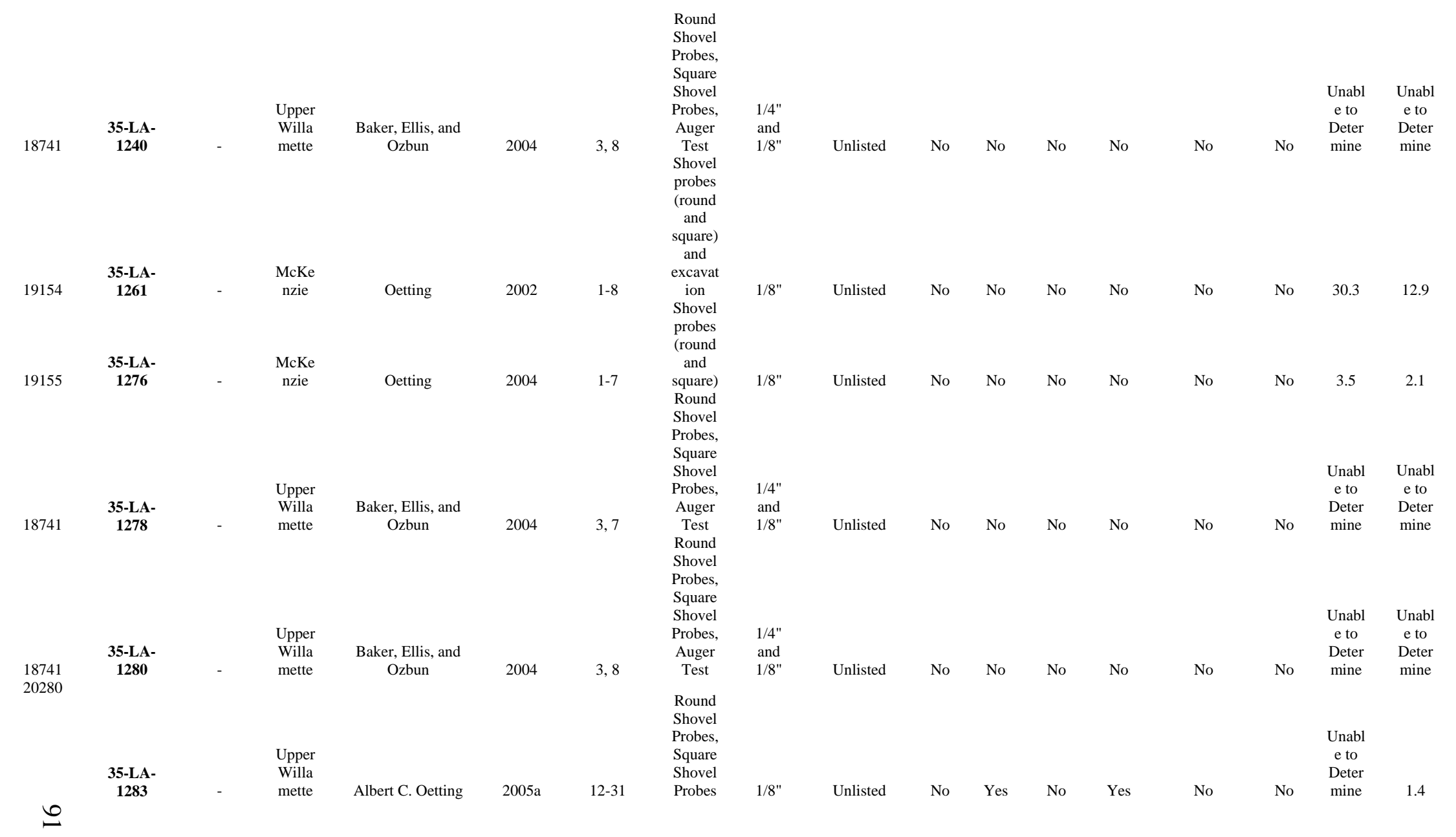




\begin{tabular}{|c|c|c|c|c|c|c|c|c|c|c|c|c|c|c|c|c|c|}
\hline & & & & & & & $\begin{array}{l}\text { Round } \\
\text { Shovel } \\
\text { Probes, } \\
\text { Square }\end{array}$ & & & & & & & & & & \\
\hline 18741 & $\begin{array}{l}\text { 35-LA- } \\
1286\end{array}$ & - & $\begin{array}{l}\text { Upper } \\
\text { Willa } \\
\text { mette }\end{array}$ & $\begin{array}{l}\text { Baker, Ellis, and } \\
\text { Ozbun }\end{array}$ & 2004 & 3-6 & $\begin{array}{c}\text { Shovel } \\
\text { Probes, } \\
\text { Auger } \\
\text { Test }\end{array}$ & $\begin{array}{l}1 / 4 " \\
\text { and } \\
1 / 8^{\prime \prime}\end{array}$ & Unlisted & No & No & No & No & No & No & $\begin{array}{l}\text { Unabl } \\
\text { e to } \\
\text { Deter } \\
\text { mine }\end{array}$ & $\begin{array}{l}\text { Unabl } \\
\text { e to } \\
\text { Deter } \\
\text { mine }\end{array}$ \\
\hline & 35-LA- & & Coast & & & & $\begin{array}{c}\text { Test } \\
\text { Pits } \\
\text { (50x50 }\end{array}$ & & & & & & & & & & \\
\hline 19597 & 1289 & - & $\begin{array}{l}\text { Fork } \\
\text { Upper }\end{array}$ & Cabebe & 2004 & 8-13 & $\begin{array}{c}\text { ) } \\
\text { Square }\end{array}$ & 1/8" & Unlisted & No & No & No & No & No & No & 1 & .85 \\
\hline 20898 & $\begin{array}{l}\text { 35-LA- } \\
1309\end{array}$ & - & $\begin{array}{l}\text { Willa } \\
\text { mette }\end{array}$ & Baker et al & 2006 & $13-32$ & $\begin{array}{l}\text { Shovel } \\
\text { Probe } \\
\text { Test Pit } \\
\text { and }\end{array}$ & 1/8" & Unlisted & No & No & No & No & No & No & $\begin{array}{c}3 \\
\text { Unabl } \\
\text { e to }\end{array}$ & $\begin{array}{c}.4 \\
\text { Unabl } \\
\text { e to }\end{array}$ \\
\hline 5209 & $\begin{array}{c}\text { 35-LA- } \\
133\end{array}$ & $\begin{array}{l}\text { Hobby } \\
\text { Field }\end{array}$ & $\begin{array}{l}\text { Coast } \\
\text { Fork }\end{array}$ & Baxter and Swift & 1983 & 6-11 & $\begin{array}{l}\text { Augeri } \\
\text { ng } \\
\text { Shovel }\end{array}$ & 1/4" & Unlisted & No & No & No & No & No & No & $\begin{array}{l}\text { Deter } \\
\text { mine }\end{array}$ & $\begin{array}{l}\text { deter } \\
\text { mine }\end{array}$ \\
\hline 8471 & $\begin{array}{c}\text { 35-LA- } \\
149\end{array}$ & - & $\begin{array}{l}\text { Upper } \\
\text { Willa } \\
\text { mette }\end{array}$ & Baxter and Minor & 1987 & $8,18-20$ & $\begin{array}{c}\text { Probe } \\
\text { (square } \\
\text { ) }\end{array}$ & $1 / 8 "$ & Unlisted & No & No & No & No & No & No & 1 & .5 \\
\hline 10533 & $\begin{array}{c}\text { 35-LA- } \\
190\end{array}$ & Olsen 1 & $\begin{array}{l}\text { Middle } \\
\text { Fork }\end{array}$ & Churchill & 1989 & 19, 29-37 & $\begin{array}{c}\text { Excava } \\
\text { tion }\end{array}$ & $1 / 8 "$ & Count & Yes & Yes & No & Yes & No & No & $\begin{array}{l}\text { Unlist } \\
\text { ed }\end{array}$ & .25 \\
\hline 10533 & $\begin{array}{c}\text { 35-LA- } \\
191\end{array}$ & Olsen 2 & $\begin{array}{l}\text { Middle } \\
\text { Fork }\end{array}$ & Churchill & 1989 & 19, 38-48 & $\begin{array}{l}\text { Excava } \\
\text { tion }\end{array}$ & 1/8" & Count & Yes & Yes & No & Yes & Yes & No & $\begin{array}{l}\text { Unlist } \\
\text { ed }\end{array}$ & .65 \\
\hline 2224 & $\begin{array}{l}\text { 35-LA- } \\
218\end{array}$ & $\begin{array}{c}\text { Flanaga } \\
n\end{array}$ & $\begin{array}{l}\text { Upper } \\
\text { Willa } \\
\text { mette }\end{array}$ & Toepel and Minor & 1980 & 6-36 & $\begin{array}{l}\text { Excava } \\
\text { tion }\end{array}$ & 1/4" & Unlisted & Yes & Yes & No & No & Yes & No & 22 & $\begin{array}{l}20.6 \\
\text { Unabl }\end{array}$ \\
\hline 8214 & $\begin{array}{c}\text { 35-LA- } \\
264 \\
35-\mathrm{LA}-\end{array}$ & GWEN & $\begin{array}{l}\text { Upper } \\
\text { Willa } \\
\text { mette } \\
\text { Coast }\end{array}$ & Baxter and Minor & 1987 & $15-19$ & $\begin{array}{l}\text { Excava } \\
\text { tion } \\
\text { Shovel }\end{array}$ & $\begin{array}{c}1 / 8 " \\
\text { Unliste }\end{array}$ & Unlisted & No & No & No & No & Yes & No & $\begin{array}{l}16 \\
\text { Unlist }\end{array}$ & $\begin{array}{l}\text { e to } \\
\text { Deter } \\
\text { mine } \\
\text { Unlist }\end{array}$ \\
\hline $\begin{array}{c}218 \\
10521\end{array}$ & 265 & - & Fork & Cole & 1978 & 6-19 & $\begin{array}{c}\text { Test } \\
\text { Shovel } \\
\text { Probe } \\
\text { and }\end{array}$ & $\mathrm{d}$ & Unlisted & No & No & No & No & No & No & ed & ed \\
\hline$\stackrel{\omega}{N}$ & $\begin{array}{l}\text { 35-LA- } \\
265\end{array}$ & $\begin{array}{l}\text { Shortrid } \\
\text { ge Park }\end{array}$ & $\begin{array}{l}\text { Coast } \\
\text { Fork }\end{array}$ & Bland & 1989 & $19-41$ & $\begin{array}{l}\text { Excava } \\
\text { tion }\end{array}$ & 1/8" & Unlisted & No & No & No & No & No & No & 8.25 & 4.125 \\
\hline
\end{tabular}




\begin{tabular}{|c|c|c|c|c|c|c|c|c|c|c|c|c|c|c|c|c|c|}
\hline 19996 & $\begin{array}{l}\text { 35-LA- } \\
285\end{array}$ & $\begin{array}{l}\text { Harringt } \\
\text { on }\end{array}$ & $\begin{array}{l}\text { Middle } \\
\text { Fork }\end{array}$ & Winkler & 2005 & 11-15 & $\begin{array}{c}\text { Excava } \\
\text { tion } \\
\text { Test } \\
\text { Probes }\end{array}$ & 1/8" & Unlisted & No & No & No & No & No & Yes & 5 & $\begin{array}{l}\text { Unabl } \\
\text { e to } \\
\text { Deter } \\
\text { mine }\end{array}$ \\
\hline 11382 & $\begin{array}{l}\text { 35-LA- } \\
295\end{array}$ & $\begin{array}{c}\text { Gate } \\
\text { Creek } \\
\# 1\end{array}$ & $\begin{array}{l}\text { Middle } \\
\text { Fork }\end{array}$ & $\begin{array}{l}\text { Flenniken, Ozbun, } \\
\text { and Markos }\end{array}$ & 1990 & 26, 31-78 & $\begin{array}{c}\text { and } \\
\text { Excava } \\
\text { tion } \\
\text { Units } \\
\text { Shovel } \\
\text { Test } \\
\text { Pits } \\
\text { and }\end{array}$ & $1 / 8^{\prime \prime}$ & Unlisted & No & No & No & No & No & No & 10.25 & 8.45 \\
\hline 2226 & 35-LA-31 & - & $\begin{array}{l}\text { Middle } \\
\text { Fork }\end{array}$ & Cole & 1988 & & $\begin{array}{c}\text { Excava } \\
\text { tion } \\
\text { Shovel } \\
\text { Test } \\
\text { Pits } \\
\text { and }\end{array}$ & $\begin{array}{c}\text { Unliste } \\
\text { d }\end{array}$ & Unlisted & No & No & No & No & No & No & $\begin{array}{l}\text { Unlist } \\
\text { ed }\end{array}$ & $\begin{array}{c}\text { Unlist } \\
\text { ed }\end{array}$ \\
\hline 2226 & 35-LA-32 & - & $\begin{array}{l}\text { Middle } \\
\text { Fork }\end{array}$ & Cole & 1988 & & $\begin{array}{c}\text { Excava } \\
\text { tion } \\
\text { Test } \\
\text { Probes } \\
\text { and }\end{array}$ & $\begin{array}{l}\text { Unliste } \\
\text { d }\end{array}$ & Unlisted & No & No & No & No & No & No & $\begin{array}{l}\text { Unlist } \\
\text { ed }\end{array}$ & $\begin{array}{c}\text { Unlist } \\
\text { ed }\end{array}$ \\
\hline 10064 & $\begin{array}{c}\text { 35-LA- } \\
320\end{array}$ & - & $\begin{array}{l}\text { Middle } \\
\text { Fork }\end{array}$ & Flenniken et al. & 1989 & $\begin{array}{c}22-24,32- \\
50\end{array}$ & $\begin{array}{c}\text { Excava } \\
\text { tion } \\
\text { Units } \\
\text { Test } \\
\text { Excava }\end{array}$ & $1 / 8^{\prime \prime}$ & Unlisted & No & No & No & No & No & No & 11 & $\begin{array}{c}\text { Unlist } \\
\text { ed }\end{array}$ \\
\hline 9868 & $\begin{array}{c}\text { 35-LA- } \\
325\end{array}$ & - & $\begin{array}{c}\text { McKe } \\
\text { nzie }\end{array}$ & Bergland & 1989a & $1-3$ & $\begin{array}{l}\text { tion } \\
\text { Units } \\
\text { Excava }\end{array}$ & $1 / 4 "$ & Unlisted & No & No & No & No & No & No & 1.5 & .75 \\
\hline 15329 & $\begin{array}{l}\text { 35-LA- } \\
328\end{array}$ & - & $\begin{array}{l}\text { McKe } \\
\text { nzie }\end{array}$ & Oetting & 1994 & $13-37$ & $\begin{array}{c}\text { tion } \\
\text { Units } \\
\text { Shovel } \\
\text { Test } \\
\text { Pits } \\
\text { and }\end{array}$ & $1 / 4 "$ & Unlisted & No & No & No & No & No & No & 2.75 & 1.7 \\
\hline $\begin{array}{l}2226 \\
15329\end{array}$ & 35-LA-33 & - & $\begin{array}{l}\text { Middle } \\
\text { Fork }\end{array}$ & Cole & 1988 & & $\begin{array}{c}\text { Excava } \\
\text { tion } \\
\text { Excava } \\
\text { tion } \\
\text { Units } \\
\text { and }\end{array}$ & $\begin{array}{c}\text { Unliste } \\
\text { d }\end{array}$ & Unlisted & No & No & No & No & No & No & $\begin{array}{l}\text { Unlist } \\
\text { ed }\end{array}$ & $\begin{array}{l}\text { Unlist } \\
\text { ed }\end{array}$ \\
\hline$\omega$ & $\begin{array}{l}\text { 35-LA- } \\
330\end{array}$ & - & $\begin{array}{l}\text { McKe } \\
\text { nzie }\end{array}$ & Oetting & 1994 & 13, 38-56 & $\begin{array}{c}\text { Shovel } \\
\text { Test } \\
\text { Probes }\end{array}$ & 1/8" & Unlisted & No & No & No & No & No & No & 3.75 & 1.825 \\
\hline
\end{tabular}




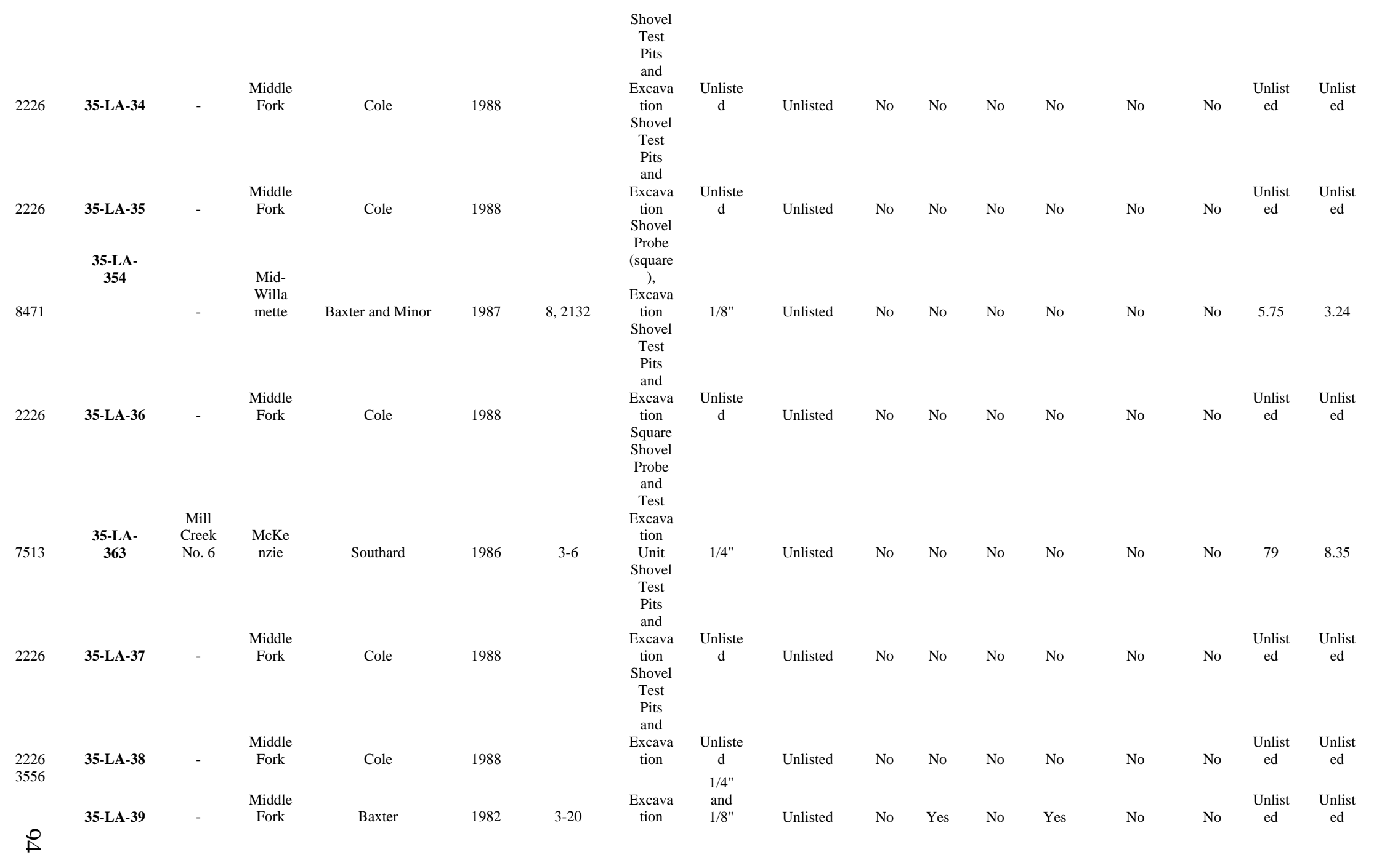




\begin{tabular}{|c|c|c|c|c|c|c|c|c|c|c|c|c|c|c|c|c|c|}
\hline 7292 & $\begin{array}{c}\text { 35-LA- } \\
390\end{array}$ & Cupola & $\begin{array}{l}\text { McKe } \\
\text { nzie } \\
\text { Upper } \\
\text { Willa } \\
\text { mette }\end{array}$ & Jenkins & 1986 & $311-347$ & $\begin{array}{l}\text { Excava } \\
\text { tion } \\
\text { Excava } \\
\text { tion }\end{array}$ & 1/4" & Unlisted & No & Yes & No & No & No & No & $\begin{array}{c}8 \\
\text { Unabl } \\
\text { e to } \\
\text { Deter } \\
\text { mine }\end{array}$ & $\begin{array}{c}4 \\
\text { Unabl } \\
\text { e to } \\
\text { Deter } \\
\text { mine }\end{array}$ \\
\hline 867 & 35-LA-42 & - & $\begin{array}{l}\text { Upper } \\
\text { Willa } \\
\text { mette }\end{array}$ & Miller & 1975 & 311-347 & $\begin{array}{l}\text { Excava } \\
\text { tion }\end{array}$ & 1/4" & Unlisted & No & No & No & Yes & Yes & No & 6 & 4.8 \\
\hline 17320 & $\begin{array}{c}\text { 35-LA- } \\
420\end{array}$ & - & $\begin{array}{l}\text { Upper } \\
\text { Willa } \\
\text { mette }\end{array}$ & $\begin{array}{l}\text { O'Neill and } \\
\text { Connolly }\end{array}$ & 1999 & 165-239 & $\begin{array}{c}\text { Excava } \\
\text { tion } \\
\text { Unit }\end{array}$ & 1/8" & Unlisted & No & No & No & No & Yes & No & 36 & $\begin{array}{l}45.1 \\
\text { Unabl } \\
\text { e to }\end{array}$ \\
\hline 4758 & $\begin{array}{c}\text { 35-LA- } \\
426\end{array}$ & - & $\begin{array}{l}\text { Middle } \\
\text { Fork }\end{array}$ & Heid & $1983 c$ & $1-4$ & $\begin{array}{c}\text { Excava } \\
\text { tion } \\
\text { Test }\end{array}$ & $1 / 4 "$ & Unlisted & No & No & No & No & No & No & 3 & $\begin{array}{l}\text { Deter } \\
\text { mine }\end{array}$ \\
\hline 4769 & $\begin{array}{l}\text { 35-LA- } \\
434\end{array}$ & Norway & $\begin{array}{l}\text { McKe } \\
\text { nzie }\end{array}$ & Bell & 1982 & 6-16 & $\begin{array}{c}\text { Probes } \\
\text { and } \\
\text { Test } \\
\text { Pits }\end{array}$ & $\begin{array}{c}\text { Unliste } \\
\text { d }\end{array}$ & Unlisted & No & No & No & No & No & No & $\begin{array}{l}4.44 \\
\text { Unabl }\end{array}$ & $\begin{array}{l}\text { Unabl } \\
\text { e to } \\
\text { Deter } \\
\text { mine } \\
\text { Unabl }\end{array}$ \\
\hline 8382 & $\begin{array}{c}\text { 35-LA- } \\
439\end{array}$ & $\begin{array}{l}\text { Long } \\
\text { Tom }\end{array}$ & $\begin{array}{l}\text { Upper } \\
\text { Willa } \\
\text { mette }\end{array}$ & O'Neill & 1987 & $25-77$ & $\begin{array}{l}\text { Auger, } \\
\text { Excava } \\
\text { tion }\end{array}$ & 1/4" & Unlisted & No & No & No & No & Yes & No & $\begin{array}{l}\mathrm{e} \text { to } \\
\text { Deter } \\
\text { mine } \\
\text { Unabl }\end{array}$ & $\begin{array}{l}\text { e to } \\
\text { Deter } \\
\text { mine } \\
\text { Unabl }\end{array}$ \\
\hline 8382 & $\begin{array}{l}\text { 35-LA- } \\
440\end{array}$ & - & $\begin{array}{l}\text { Upper } \\
\text { Willa } \\
\text { mette }\end{array}$ & O'Neill & 1987 & 78-92 & $\begin{array}{c}\text { Auger, } \\
\text { Excava } \\
\text { tion } \\
\text { Test } \\
\text { Probes } \\
\text { and }\end{array}$ & $1 / 4 "$ & Unlisted & No & No & No & No & No & No & $\begin{array}{l}\mathrm{e} \text { to } \\
\text { Deter } \\
\text { mine }\end{array}$ & $\begin{array}{l}\text { e to } \\
\text { Deter } \\
\text { mine }\end{array}$ \\
\hline 10064 & $\begin{array}{l}\text { 35-LA- } \\
444\end{array}$ & - & $\begin{array}{l}\text { Middle } \\
\text { Fork }\end{array}$ & Flenniken et al. & 1989 & $\begin{array}{c}22-24,50- \\
68\end{array}$ & $\begin{array}{c}\text { Excava } \\
\text { tion } \\
\text { Units } \\
\text { Test }\end{array}$ & $1 / 8 "$ & Unlisted & No & No & No & No & No & No & 13 & $\begin{array}{l}\text { Unlist } \\
\text { ed }\end{array}$ \\
\hline 11128 & $\begin{array}{c}\text { 35-LA- } \\
458\end{array}$ & $\begin{array}{c}\text { Pat } \\
\text { Saddle } \\
\text { Hatcher }\end{array}$ & $\begin{array}{l}\text { McKe } \\
\text { nzie }\end{array}$ & Bergland & 1990a & $1-3$ & $\begin{array}{l}\text { Excava } \\
\text { tion } \\
\text { Units }\end{array}$ & 1/4" & Unlisted & No & No & No & No & No & No & 3.75 & 1.875 \\
\hline $\begin{array}{l}8400 \\
8407\end{array}$ & $\begin{array}{c}\text { 35-LA- } \\
469\end{array}$ & $\begin{array}{c}\mathrm{y} \\
\text { Tributar } \\
\mathrm{y}\end{array}$ & $\begin{array}{l}\text { McKe } \\
\text { nzie }\end{array}$ & Southard & 1987 & $4-21$ & $\begin{array}{c}\text { Shovel } \\
\text { Test } \\
\text { Units }\end{array}$ & $\begin{array}{l}1 / 4 " \\
\text { and } \\
1 / 8 "\end{array}$ & Unlisted & No & No & No & No & No & No & 6 & $\begin{array}{l}1.7125 \\
\text { Unabl }\end{array}$ \\
\hline תט & $\begin{array}{c}\text { 35-LA- } \\
475\end{array}$ & - & $\begin{array}{l}\text { Middle } \\
\text { Fork }\end{array}$ & Heid & 1987 & $5-14$ & $\begin{array}{l}\text { Shovel } \\
\text { Probes }\end{array}$ & 1/4" & Unlisted & No & No & No & No & No & No & 23 & $\begin{array}{l}\text { e to } \\
\text { Deter }\end{array}$ \\
\hline
\end{tabular}




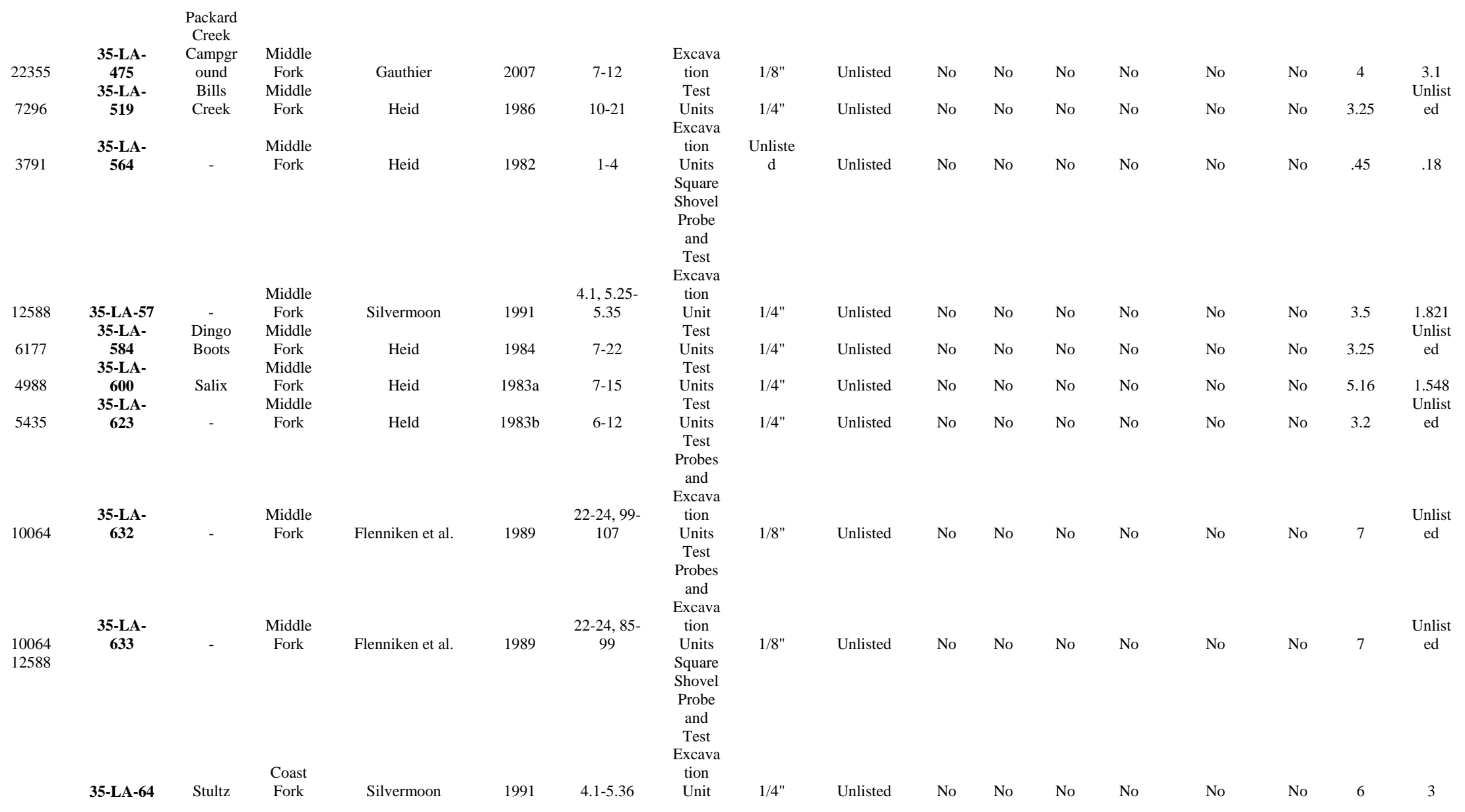




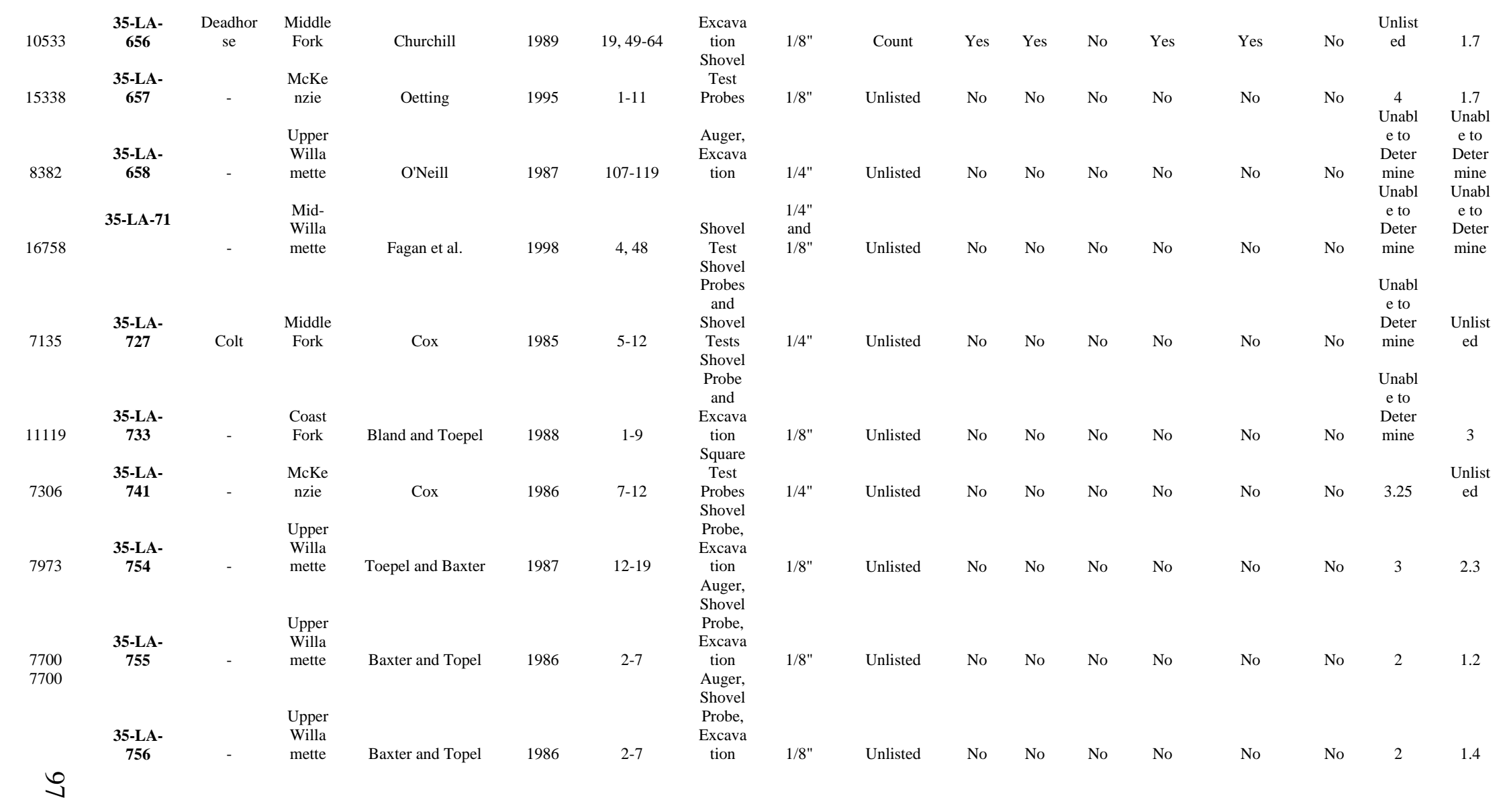




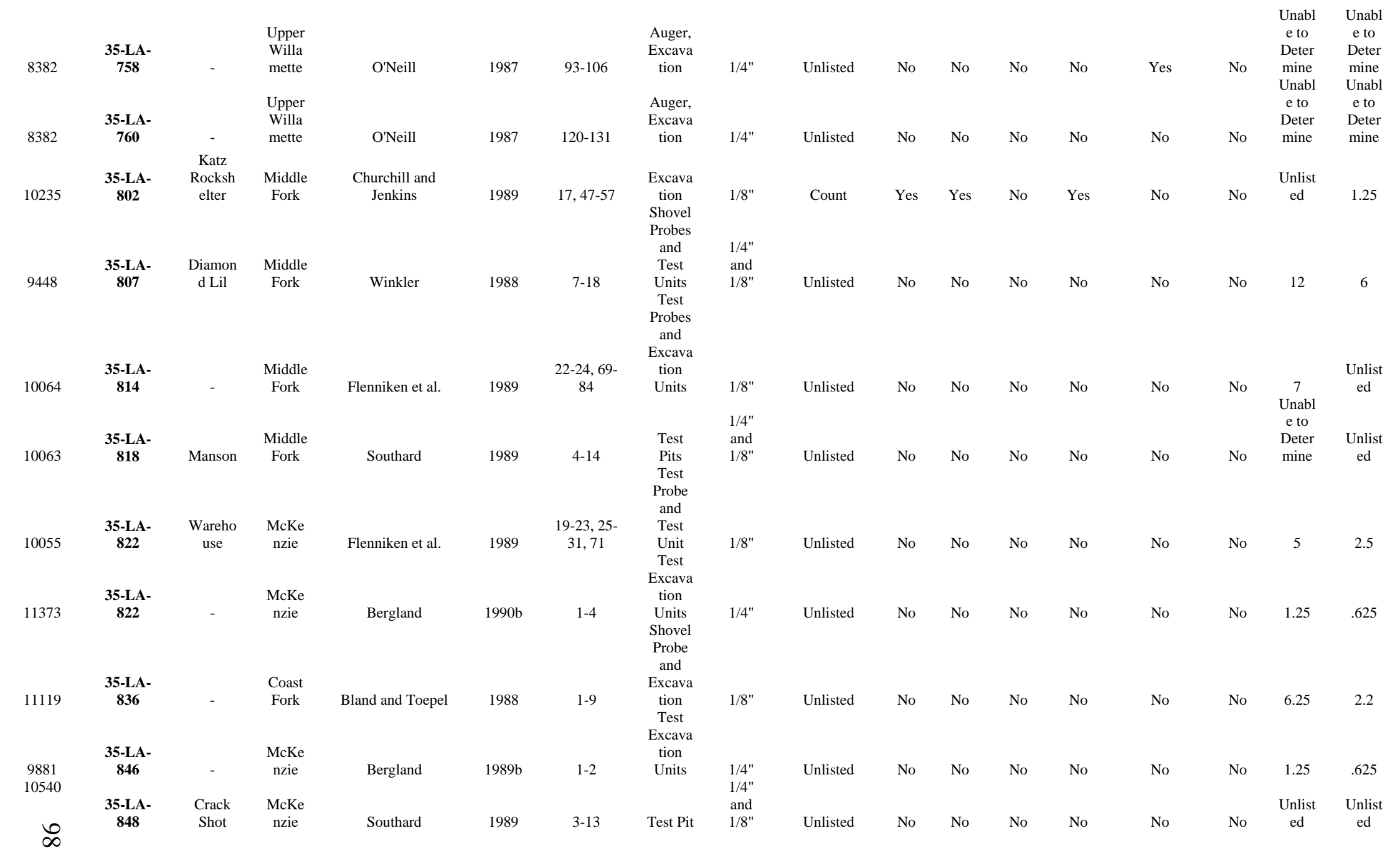




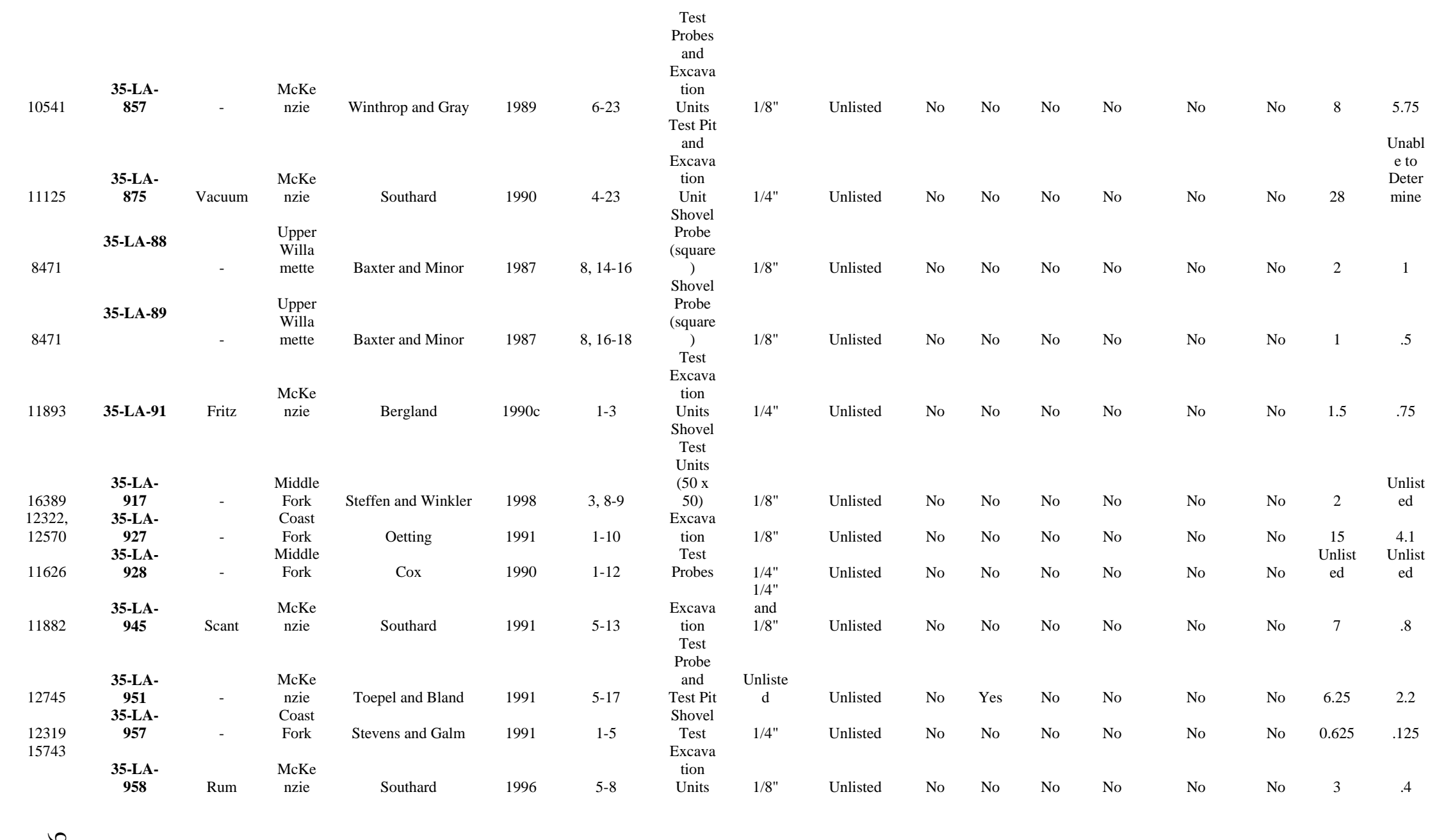




\begin{tabular}{|c|c|c|c|c|c|c|c|c|c|c|c|c|c|c|c|c|c|}
\hline 12588 & $\begin{array}{c}\text { 35-LA- } \\
969\end{array}$ & $\begin{array}{c}\text { William } \\
\text { son }\end{array}$ & $\begin{array}{l}\text { Coast } \\
\text { Fork }\end{array}$ & Silvermoon & 1991 & 4.1-5.36 & $\begin{array}{c}\text { Square } \\
\text { Shovel } \\
\text { Probe } \\
\text { and } \\
\text { Test } \\
\text { Excava } \\
\text { tion } \\
\text { Unit }\end{array}$ & $1 / 4 "$ & Unlisted & No & No & No & No & No & No & 2.75 & 1.375 \\
\hline 13032 & $\begin{array}{c}\text { 35-LA- } \\
978\end{array}$ & - & $\begin{array}{l}\text { Mid- } \\
\text { Willa } \\
\text { mette }\end{array}$ & Fagan et al. & 1992 & $\begin{array}{l}48,338- \\
346\end{array}$ & $\begin{array}{c}\text { Excava } \\
\text { tion, } \\
\text { Auger }\end{array}$ & $\begin{array}{l}\text { Unliste } \\
\text { d }\end{array}$ & Unlisted & No & No & No & No & No & No & 5 & 6.5 \\
\hline & 35-LA- & & McKe & & & & $\begin{array}{l}\text { Test } \\
\text { Pits } \\
\text { (50x50 }\end{array}$ & & & & & & & & & & \\
\hline 17898 & 987 & $\begin{array}{c}- \\
\text { Winberr }\end{array}$ & nzie & South and Bergland & 1997 & $1-3$ & ) & $1 / 8^{\prime \prime}$ & Unlisted & No & No & No & No & No & No & 1.75 & 0.575 \\
\hline 12960 & $\begin{array}{l}\text { 35-LA- } \\
995\end{array}$ & $\begin{array}{c}\mathrm{y} \\
\text { Saddle }\end{array}$ & $\begin{array}{l}\text { Middle } \\
\text { Fork }\end{array}$ & Winkler & 1992 & $11-17$ & $\begin{array}{c}\text { Test } \\
\text { Probes } \\
\text { Shovel }\end{array}$ & $1 / 8 "$ & Unlisted & No & No & No & No & No & No & 4.25 & 2.725 \\
\hline 21066 & $\begin{array}{l}\text { 35-LIN- } \\
1116\end{array}$ & - & $\begin{array}{l}\text { McKe } \\
\text { nzie }\end{array}$ & Oetting & 2006 & $15-18,44$ & $\begin{array}{l}\text { probes } \\
\text { (round } \\
\text { and } \\
\text { square) }\end{array}$ & $1 / 8 "$ & Unlisted & No & No & No & No & No & No & $\begin{array}{l}\text { Unabl } \\
\text { e to } \\
\text { Deter } \\
\text { mine }\end{array}$ & 1.2 \\
\hline 6710 & $\begin{array}{c}\text { 35-LIN- } \\
1118\end{array}$ & Yukwah & $\begin{array}{c}\text { S. } \\
\text { Santia } \\
\text { m }\end{array}$ & & & & $\begin{array}{c}\text { Excava } \\
\text { tion }\end{array}$ & & Unlisted & No & No & No & No & No & No & 7.75 & 4.85 \\
\hline $6 / 10$ & 35-LIN- & Yukwah & $\begin{array}{c}\mathrm{m} \\
\mathrm{N} . \\
\text { Santia }\end{array}$ & Lindberg-Muir & 1964 & $5-8$ & $\begin{array}{c}\text { tion } \\
\text { Excava }\end{array}$ & $1 / 4^{\prime \prime}$ & Unilsted & No & No & No & No & No & & 1.15 & \\
\hline 7317 & 133 & - & $\mathrm{m}$ & Elsesser & 1985 & $8-11$ & $\begin{array}{l}\text { tion } \\
\text { Excava } \\
\text { tion } \\
\text { and } \\
\text { Test } \\
\text { Pits }\end{array}$ & $1 / 4 "$ & Unlisted & No & No & No & No & No & No & 5.25 & 2.625 \\
\hline 7144 & $\begin{array}{c}\text { 35-LIN- } \\
139\end{array}$ & $\begin{array}{c}- \\
\text { North }\end{array}$ & $\begin{array}{c}\text { Santia } \\
\mathrm{m} \\
\mathrm{N} .\end{array}$ & Winthrop and Gray & 1985 & $10-18$ & $\begin{array}{c}(50 \times 50 \\
)\end{array}$ & $1 / 4 "$ & Unlisted & No & No & No & No & No & No & 8 & $\begin{array}{l}\text { Unlist } \\
\text { ed }\end{array}$ \\
\hline 8009 & $\begin{array}{c}\text { 35-LIN- } \\
186\end{array}$ & $\begin{array}{l}\text { Park } \\
\text { Salvage }\end{array}$ & $\begin{array}{c}\text { Santia } \\
\text { m }\end{array}$ & $\begin{array}{l}\text { Jenkins and } \\
\text { Churchill }\end{array}$ & 1987 & $\begin{array}{c}\text { iii-viii, } 12- \\
13\end{array}$ & $\begin{array}{c}\text { Excava } \\
\text { tion } \\
\text { Test } \\
\text { Pit, }\end{array}$ & $1 / 4 "$ & Unlisted & No & No & No & No & No & No & 8 & 6.9 \\
\hline $\begin{array}{l}18691 \\
18691\end{array}$ & $\begin{array}{c}\text { 35-LIN- } \\
187\end{array}$ & - & $\begin{array}{c}\mathrm{N} . \\
\text { Santia } \\
\mathrm{m}\end{array}$ & Helzer & 2003 & $17-30$ & $\begin{array}{c}\text { Excava } \\
\text { tion, } \\
\text { Auger } \\
\text { Test }\end{array}$ & $1 / 8 "$ & Unlisted & No & No & No & No & No & No & 1.34 & .04 \\
\hline ஜ & $\begin{array}{c}\text { 35-LIN- } \\
188\end{array}$ & - & $\begin{array}{c}\mathrm{N} . \\
\text { Santia } \\
\mathrm{m}\end{array}$ & Helzer & 2003 & $17-30$ & $\begin{array}{l}\text { Pit, } \\
\text { Excava } \\
\text { tion, }\end{array}$ & $1 / 8 "$ & Unlisted & No & No & No & No & No & No & .25 & .1 \\
\hline
\end{tabular}




\begin{tabular}{|c|c|c|c|c|c|c|c|c|c|c|c|c|c|c|c|c|c|}
\hline 12371 & $\begin{array}{l}\text { 35-LIN- } \\
22\end{array}$ & $\begin{array}{l}\text { Kropf } \\
\text { Soda }\end{array}$ & $\begin{array}{c}\text { Upper } \\
\text { Willa } \\
\text { mette } \\
\text { S. }\end{array}$ & Davis & 1970 & 9-32 & $\begin{array}{c}\text { Unliste } \\
\text { d }\end{array}$ & $\begin{array}{l}\text { Unliste } \\
\text { d }\end{array}$ & Unlisted & No & No & No & No & No & No & $\begin{array}{l}\text { Unlist } \\
\text { ed }\end{array}$ & $\begin{array}{c}\text { Unlist } \\
\text { ed }\end{array}$ \\
\hline 5449 & $\begin{array}{l}\text { 35-LIN- } \\
230\end{array}$ & $\begin{array}{c}\text { Fork } \\
\text { Way II } \\
\text { Soda }\end{array}$ & $\begin{array}{c}\text { Santia } \\
\text { m } \\
\text { S. }\end{array}$ & Lindberg-Muir & $1983 b$ & 3-6 & $\begin{array}{l}\text { Excava } \\
\text { tion }\end{array}$ & 1/4" & Unlisted & No & No & No & No & No & No & 2.34 & 0.91 \\
\hline 5448 & $\begin{array}{c}\text { 35-LIN- } \\
231\end{array}$ & $\begin{array}{c}\text { Fork } \\
\text { Way I }\end{array}$ & $\begin{array}{l}\text { Santia } \\
\mathrm{m}\end{array}$ & Lindberg-Muir & 1983a & 3-6 & $\begin{array}{c}\text { Excava } \\
\text { tion } \\
\text { Test }\end{array}$ & 1/4" & Unlisted & No & No & No & No & No & No & .63 & 0.2331 \\
\hline 4578 & $\begin{array}{l}\text { 35-LIN- } \\
241\end{array}$ & $\begin{array}{c}\text { - } \\
\text { North } \\
\text { Park }\end{array}$ & $\begin{array}{c}\text { N. } \\
\text { Santia } \\
\mathrm{m} \\
\mathrm{N} .\end{array}$ & Bell & 1982 & $4-12$ & $\begin{array}{c}\text { Probes, } \\
\text { Test } \\
\text { Pits }\end{array}$ & $\begin{array}{l}\text { Unliste } \\
\text { d }\end{array}$ & Unlisted & No & No & No & No & No & No & 2 & 1.2 \\
\hline 8009 & $\begin{array}{l}\text { 35-LIN- } \\
253\end{array}$ & $\begin{array}{l}\text { Headwa } \\
\text { ters }\end{array}$ & $\begin{array}{l}\text { Santia } \\
\mathrm{m}\end{array}$ & $\begin{array}{l}\text { Jenkins and } \\
\text { Churchill }\end{array}$ & 1987 & iii-viii, 12 & $\begin{array}{l}\text { Excava } \\
\text { tion }\end{array}$ & 1/4" & Unlisted & No & No & No & No & No & No & 11.5 & $\begin{array}{c}3.3 \\
\text { Unabl } \\
\text { e to }\end{array}$ \\
\hline 7539 & $\begin{array}{l}\text { 35-LIN- } \\
292\end{array}$ & - & $\begin{array}{l}\text { Upper } \\
\text { Willa } \\
\text { mette } \\
\text { S. }\end{array}$ & Lebow & 1986 & $15-25$ & $\begin{array}{l}\text { Excava } \\
\text { tion }\end{array}$ & $1 / 4 "$ & Unlisted & No & No & No & No & No & No & 5 & $\begin{array}{l}\text { e to } \\
\text { Deter } \\
\text { mine }\end{array}$ \\
\hline 7542 & $\begin{array}{l}\text { 35-LIN- } \\
301\end{array}$ & Dopey & $\begin{array}{c}\text { Santia } \\
\text { m } \\
\text { S. }\end{array}$ & Elsesser & 1985 & $6-13$ & $\begin{array}{l}\text { Excava } \\
\text { tion }\end{array}$ & $\begin{array}{l}\text { Unliste } \\
\text { d }\end{array}$ & Unlisted & No & No & No & No & No & No & 8 & $\begin{array}{c}\text { Unlist } \\
\text { ed }\end{array}$ \\
\hline 9899 & $\begin{array}{l}\text { 35-LIN- } \\
301\end{array}$ & $\begin{array}{c}\text { Bear } \\
\text { Saddle }\end{array}$ & $\begin{array}{c}\text { Santia } \\
\mathrm{m}\end{array}$ & Nilsson & 1989 & 23,26 & $\begin{array}{c}\text { Excava } \\
\text { tion } \\
\text { Shovel } \\
\text { Test } \\
\text { and }\end{array}$ & 1/8" & Unlisted & No & No & No & No & No & No & 20 & $\begin{array}{l}\text { Unlist } \\
\text { ed }\end{array}$ \\
\hline 9900 & $\begin{array}{c}\text { 35-LIN- } \\
302\end{array}$ & Moose & $\begin{array}{l}\text { Santia } \\
\text { m } \\
\text { S. }\end{array}$ & Spencer & 1989 & $12-47$ & $\begin{array}{l}\text { Excava } \\
\text { tion }\end{array}$ & $1 / 8^{\prime \prime}$ & Unlisted & No & No & No & No & No & No & 8 & $\begin{array}{c}\text { Unlist } \\
\text { ed }\end{array}$ \\
\hline 8004 & $\begin{array}{c}\text { 35-LIN- } \\
310\end{array}$ & $\begin{array}{c}\text { Ridge } \\
\# 4 \\
\text { Moose }\end{array}$ & $\begin{array}{c}\text { Santia } \\
\text { m } \\
\text { S. }\end{array}$ & Cox & 1987 & $7-8$ & $\begin{array}{l}\text { Excava } \\
\text { tion }\end{array}$ & $1 / 4^{\prime \prime}$ & Unlisted & No & No & No & No & No & No & 1 & .4 \\
\hline 8005 & $\begin{array}{l}\text { 35-LIN- } \\
311\end{array}$ & $\begin{array}{c}\text { Ridge } \\
\text { \#3 } \\
\text { Three }\end{array}$ & $\begin{array}{c}\text { Santia } \\
\mathrm{m}\end{array}$ & Prouty and Cox & 1987 & $5-6$ & $\begin{array}{l}\text { Excava } \\
\text { tion }\end{array}$ & 1/4" & Unlisted & No & No & No & No & No & No & 5 & 3.5 \\
\hline $\begin{array}{l}8251 \\
9904\end{array}$ & $\begin{array}{l}\text { 35-LIN- } \\
312\end{array}$ & $\begin{array}{l}\text { Chimne } \\
\text { y Peak } \\
\text { One } \\
\text { Chimne }\end{array}$ & $\begin{array}{c}\text { S. } \\
\text { Santia } \\
\text { m } \\
\text { S. }\end{array}$ & Lindberg-Muir & 1986 & $5-10$ & $\begin{array}{l}\text { Excava } \\
\text { tion }\end{array}$ & 1/4" & Unlisted & No & No & No & No & No & No & 4.5 & 1.755 \\
\hline 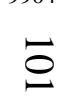 & $\begin{array}{c}\text { 35-LIN- } \\
312\end{array}$ & $\begin{array}{l}\text { y Peak } \\
\text { One }\end{array}$ & $\begin{array}{c}\text { Santia } \\
\mathrm{m}\end{array}$ & $\begin{array}{l}\text { Jenkins and } \\
\text { Churchill }\end{array}$ & 1988 & $11-22$ & $\begin{array}{l}\text { Excava } \\
\text { tion }\end{array}$ & 1/8" & Unlisted & No & No & No & No & No & No & 20 & $\begin{array}{c}\text { Unlist } \\
\text { ed }\end{array}$ \\
\hline
\end{tabular}




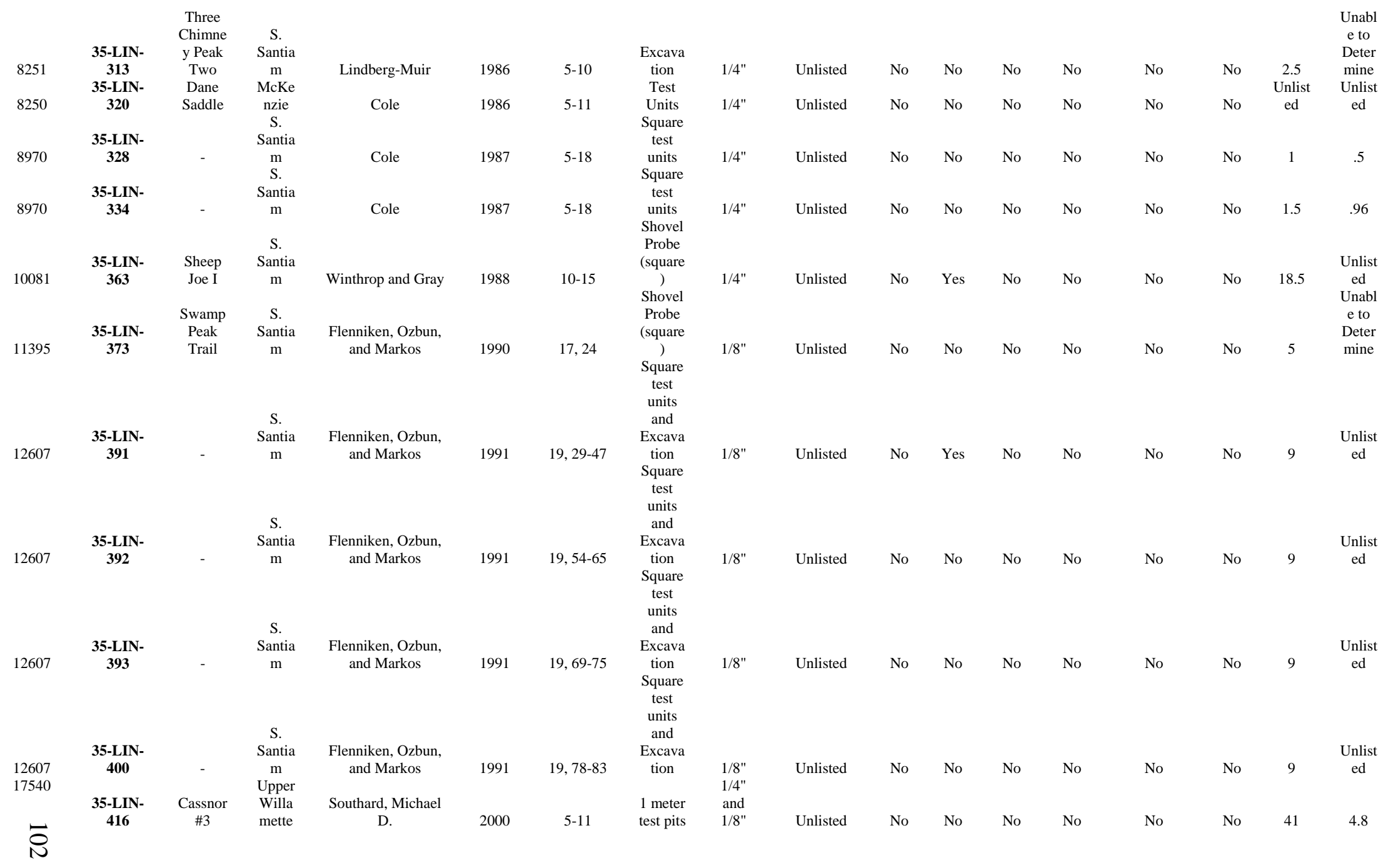




\begin{tabular}{|c|c|c|c|c|c|c|c|c|c|c|c|c|c|c|c|c|c|}
\hline 20499 & $\begin{array}{l}\text { 35-LIN- } \\
428\end{array}$ & - & $\begin{array}{l}\text { Upper } \\
\text { Willa } \\
\text { mette }\end{array}$ & $\begin{array}{l}\text { Henrickson and } \\
\text { Winterhoff }\end{array}$ & 2005 & $14-19$ & $\begin{array}{c}\text { Square } \\
\text { Shovel } \\
\text { Probe }\end{array}$ & $1 / 8 "$ & Unlisted & No & No & No & No & No & No & 1.25 & .65 \\
\hline 13032 & $\begin{array}{l}\text { 35-LIN- } \\
429\end{array}$ & - & $\begin{array}{l}\text { Mid- } \\
\text { Willa } \\
\text { mette }\end{array}$ & Fagan et al. & 1992 & $\begin{array}{l}48,255- \\
256\end{array}$ & $\begin{array}{l}\text { Shovel } \\
\text { test, } \\
\text { Auger }\end{array}$ & $\begin{array}{l}\text { Unliste } \\
\mathrm{d}\end{array}$ & Unlisted & No & No & No & No & No & No & .75 & .32 \\
\hline 13032 & $\begin{array}{l}\text { 35-LIN- } \\
435\end{array}$ & - & $\begin{array}{l}\text { Mid- } \\
\text { Willa } \\
\text { mette }\end{array}$ & Fagan et al. & 1992 & $\begin{array}{l}48,283- \\
284\end{array}$ & $\begin{array}{l}\text { Excava } \\
\text { tion, } \\
\text { Auger }\end{array}$ & $\begin{array}{l}\text { Unliste } \\
\quad \mathrm{d}\end{array}$ & Unlisted & No & No & No & No & No & No & 1 & 1 \\
\hline 13032 & $\begin{array}{l}\text { 35-LIN- } \\
437\end{array}$ & - & $\begin{array}{l}\text { Mid- } \\
\text { Willa } \\
\text { mette }\end{array}$ & Fagan et al. & 1992 & $\begin{array}{l}48,298- \\
313\end{array}$ & $\begin{array}{l}\text { Shovel } \\
\text { test, } \\
\text { Auger }\end{array}$ & $\begin{array}{l}\text { Unliste } \\
\mathrm{d}\end{array}$ & Unlisted & No & No & No & No & No & No & 1 & .75 \\
\hline 13032 & $\begin{array}{l}\text { 35-LIN- } \\
442\end{array}$ & - & $\begin{array}{l}\text { Mid- } \\
\text { Willa } \\
\text { mette }\end{array}$ & Fagan et al. & 1992 & $\begin{array}{l}48,298- \\
313\end{array}$ & $\begin{array}{c}\text { Excava } \\
\text { tion, } \\
\text { Shovel } \\
\text { Test, } \\
\text { Auger }\end{array}$ & $\begin{array}{l}\text { Unliste } \\
\text { d }\end{array}$ & Unlisted & No & No & No & No & No & No & 3 & 1.71 \\
\hline 13032 & $\begin{array}{l}\text { 35-LIN- } \\
443\end{array}$ & - & $\begin{array}{l}\text { Mid- } \\
\text { Willa } \\
\text { mette }\end{array}$ & Fagan et al. & 1992 & $\begin{array}{l}48,279- \\
280\end{array}$ & $\begin{array}{l}\text { Excava } \\
\text { tion, } \\
\text { Auger }\end{array}$ & $\begin{array}{l}\text { Unliste } \\
\text { d }\end{array}$ & Unlisted & No & No & No & No & No & No & 2 & 1 \\
\hline 13032 & $\begin{array}{l}\text { 35-LIN- } \\
451\end{array}$ & - & $\begin{array}{l}\text { Mid- } \\
\text { Willa } \\
\text { mette }\end{array}$ & Fagan et al. & 1992 & $\begin{array}{l}48,316- \\
330\end{array}$ & $\begin{array}{l}\text { Excava } \\
\text { tion, } \\
\text { Auger }\end{array}$ & $\begin{array}{l}\text { Unliste } \\
\mathrm{d}\end{array}$ & Unlisted & No & No & No & No & No & No & 4 & 4.25 \\
\hline 13032 & $\begin{array}{l}\text { 35-LIN- } \\
457\end{array}$ & - & $\begin{array}{c}\text { S. } \\
\text { Santia } \\
\text { m }\end{array}$ & Fagan et al. & $\begin{array}{l}1992, \\
1996\end{array}$ & $\begin{array}{l}48,202- \\
214\end{array}$ & $\begin{array}{l}\text { Excava } \\
\text { tion, } \\
\text { Auger }\end{array}$ & $\begin{array}{l}\text { Unliste } \\
\mathrm{d}\end{array}$ & Unlisted & No & No & No & No & No & No & 2 & $\begin{array}{l}\text { Unabl } \\
\text { e to } \\
\text { Deter } \\
\text { mine }\end{array}$ \\
\hline 13032 & $\begin{array}{l}\text { 35-LIN- } \\
458\end{array}$ & - & $\begin{array}{c}\text { S. } \\
\text { Santia } \\
\text { m }\end{array}$ & Fagan et al. & 1992 & $\begin{array}{l}48,201- \\
202\end{array}$ & $\begin{array}{l}\text { Excava } \\
\text { tion, } \\
\text { Auger }\end{array}$ & $\begin{array}{l}\text { Unliste } \\
\quad \mathrm{d}\end{array}$ & Unlisted & No & No & No & No & No & No & 1 & 1 \\
\hline \multirow[t]{2}{*}{$\begin{array}{l}13032 \\
13032\end{array}$} & $\begin{array}{l}\text { 35-LIN- } \\
459\end{array}$ & - & $\begin{array}{l}\text { Mid- } \\
\text { Willa } \\
\text { mette }\end{array}$ & Fagan et al. & $\begin{array}{l}1992, \\
1996\end{array}$ & $\begin{array}{l}48,215- \\
231\end{array}$ & $\begin{array}{c}\text { Excava } \\
\text { tion, } \\
\text { Auger }\end{array}$ & $\begin{array}{l}\text { Unliste } \\
\text { d }\end{array}$ & Unlisted & No & No & No & No & No & No & 2 & $\begin{array}{c}.9 \\
\text { Unabl }\end{array}$ \\
\hline & $\begin{array}{l}\text { 35-LIN- } \\
460 / 461\end{array}$ & - & $\begin{array}{l}\text { Mid- } \\
\text { Willa } \\
\text { mette }\end{array}$ & Fagan et al. & 1992 & $\begin{array}{l}48,214- \\
215\end{array}$ & $\begin{array}{c}\text { Excava } \\
\text { tion, } \\
\text { Auger }\end{array}$ & $\begin{array}{l}\text { Unliste } \\
\text { d }\end{array}$ & Unlisted & No & No & No & No & No & No & .25 & $\begin{array}{l}\text { e to } \\
\text { Deter } \\
\text { mine }\end{array}$ \\
\hline
\end{tabular}




\begin{tabular}{|c|c|c|c|c|c|c|c|c|c|c|c|c|c|c|c|c|c|}
\hline 13032 & $\begin{array}{c}\text { 35-LIN- } \\
468\end{array}$ & - & $\begin{array}{l}\text { Mid- } \\
\text { Willa } \\
\text { mette }\end{array}$ & Fagan et al. & 1992 & $\begin{array}{l}48,257- \\
276\end{array}$ & $\begin{array}{l}\text { Excava } \\
\text { tion, } \\
\text { Auger }\end{array}$ & $\begin{array}{l}1 / 4 " \\
\text { and } \\
1 / 8 "\end{array}$ & $\begin{array}{l}\text { NISP, MNI, } \\
\text { Weight }\end{array}$ & Yes & Yes & No & No & No & No & 4 & 3.63 \\
\hline 13032 & $\begin{array}{c}\text { 35-LIN- } \\
470\end{array}$ & - & $\begin{array}{c}\text { Mid- } \\
\text { Willa } \\
\text { mette } \\
\text { S. }\end{array}$ & Fagan et al. & 1992 & $\begin{array}{l}48,286- \\
296\end{array}$ & $\begin{array}{c}\text { Excava } \\
\text { tion, } \\
\text { Auger } \\
\text { Excava } \\
\text { tion }\end{array}$ & $\begin{array}{l}\text { Unliste } \\
\mathrm{d}\end{array}$ & Unlisted & No & No & No & No & No & No & 2 & 1.04 \\
\hline 15208 & $\begin{array}{c}\text { 35-LIN- } \\
503\end{array}$ & - & $\begin{array}{c}\text { Santia } \\
\mathrm{m} \\
\mathrm{N} .\end{array}$ & $\begin{array}{c}\text { Flenniken and } \\
\text { Ozbun }\end{array}$ & 1994 & 20,68 & $\begin{array}{l}\text { Test } \\
\text { Unit }\end{array}$ & $1 / 8^{\prime \prime}$ & Unlisted & No & No & No & No & No & No & 6 & 7.4 \\
\hline 15100 & $\begin{array}{c}\text { 35-LIN- } \\
525\end{array}$ & - & $\begin{array}{c}\text { Santia } \\
\text { m }\end{array}$ & Draper et. Al. & 1994 & $40,68-104$ & $\begin{array}{c}\text { Excava } \\
\text { tion } \\
\text { Shovel }\end{array}$ & $1 / 8 "$ & Unlisted & No & No & No & No & No & No & $\begin{array}{c}7 \\
\text { Unabl }\end{array}$ & $\begin{array}{r}5.95 \\
\text { Unab }\end{array}$ \\
\hline 13611 & $\begin{array}{c}\text { 35-LIN- } \\
554\end{array}$ & - & $\begin{array}{l}\text { Upper } \\
\text { Willa } \\
\text { mette }\end{array}$ & Regan and Thomas & 1993 & 5 & $\begin{array}{c}\text { Tests, } \\
\text { Excava } \\
\text { tion } \\
\text { Shovel }\end{array}$ & $\begin{array}{l}\text { Unliste } \\
\text { d }\end{array}$ & Unlisted & No & No & No & No & No & No & $\begin{array}{l}\text { e to } \\
\text { Deter } \\
\text { mine }\end{array}$ & $\begin{array}{l}\text { e to } \\
\text { Deter } \\
\text { mine }\end{array}$ \\
\hline 14450 & $\begin{array}{c}\text { 35-LIN- } \\
572\end{array}$ & - & $\begin{array}{c}\text { S. } \\
\text { Santia } \\
\text { m }\end{array}$ & Linderman & 1992 & $1-3$ & $\begin{array}{c}\text { Probe } \\
\text { (square } \\
\text { ) } \\
\text { Shovel }\end{array}$ & $1 / 8 "$ & Unlisted & No & No & No & No & No & No & 3.5 & 1.575 \\
\hline 14459 & $\begin{array}{c}\text { 35-LIN- } \\
606\end{array}$ & - & $\begin{array}{c}\text { S. } \\
\text { Santia } \\
\text { m }\end{array}$ & Linderman & 1992 & $1-4$ & $\begin{array}{c}\text { Probe } \\
\text { (square } \\
\text { ) } \\
\text { Shovel }\end{array}$ & $1 / 8^{\prime \prime}$ & Unlisted & No & No & No & No & No & No & $\begin{array}{c}3.5 \\
\text { Unabl }\end{array}$ & 1.175 \\
\hline 15744 & $\begin{array}{c}\text { 35-LIN- } \\
624\end{array}$ & - & $\begin{array}{l}\text { Upper } \\
\text { Willa } \\
\text { mette }\end{array}$ & Lebow et al. & 1996 & $\begin{array}{c}\text { 3.1-3.10, } \\
6.1-6.2\end{array}$ & $\begin{array}{c}\text { Probe, } \\
\text { Excava } \\
\text { tion } \\
\text { Shovel }\end{array}$ & $1 / 4 "$ & Unlisted & No & No & No & No & No & No & $\begin{array}{l}\text { e to } \\
\text { Deter } \\
\text { mine } \\
\text { Unabl }\end{array}$ & 1.88 \\
\hline 15744 & $\begin{array}{c}\text { 35-LIN- } \\
625\end{array}$ & - & $\begin{array}{l}\text { Upper } \\
\text { Willa } \\
\text { mette }\end{array}$ & Lebow et al. & 1996 & $\begin{array}{c}\text { 3.1-3.10 } \\
7.1\end{array}$ & $\begin{array}{c}\text { Probe, } \\
\text { Excava } \\
\text { tion } \\
\text { Shovel }\end{array}$ & $1 / 4 "$ & Unlisted & No & No & No & No & No & No & $\begin{array}{l}\text { e to } \\
\text { Deter } \\
\text { mine } \\
\text { Unabl }\end{array}$ & 4.61 \\
\hline 15744 & $\begin{array}{c}\text { 35-LIN- } \\
626\end{array}$ & - & $\begin{array}{l}\text { Upper } \\
\text { Willa } \\
\text { mette }\end{array}$ & Lebow et al. & 1996 & $\begin{array}{l}\text { 3.1-3.10, } \\
8.2-8.24\end{array}$ & $\begin{array}{c}\text { Probe, } \\
\text { Excava } \\
\text { tion }\end{array}$ & $1 / 4 "$ & Unlisted & No & No & No & Yes & No & No & $\begin{array}{l}\text { e to } \\
\text { Deter } \\
\text { mine }\end{array}$ & 6.35 \\
\hline ஜ & $\begin{array}{c}\text { 35-LIN- } \\
628\end{array}$ & - & $\begin{array}{l}\text { Upper } \\
\text { Willa } \\
\text { mette }\end{array}$ & Lebow et al. & 1996 & $\begin{array}{l}\text { 3.1-3.10, } \\
9.2-9.19\end{array}$ & $\begin{array}{c}\text { Shovel } \\
\text { Probe, } \\
\text { Excava } \\
\text { tion }\end{array}$ & $1 / 4 "$ & Unlisted & No & No & No & Yes & Yes & No & $\begin{array}{l}\text { Unabl } \\
\text { e to } \\
\text { Deter } \\
\text { mine }\end{array}$ & 7.82 \\
\hline
\end{tabular}




\begin{tabular}{|c|c|c|c|c|c|c|c|c|c|c|c|c|c|c|c|c|c|}
\hline 20619 & $\begin{array}{c}\text { 35-LIN- } \\
650\end{array}$ & - & $\begin{array}{c}\text { S. } \\
\text { Santia } \\
\mathrm{m} \\
\text { Upper }\end{array}$ & $\begin{array}{l}\text { Baxter and } \\
\text { Connolly }\end{array}$ & 2006 & 6-11 & $\begin{array}{c}\text { Shovel } \\
\text { Probe } \\
\text { (square } \\
\text { ) }\end{array}$ & $1 / 8 "$ & Unlisted & No & No & No & No & No & No & 3.75 & 4.35 \\
\hline 20619 & $\begin{array}{c}\text { 35-LIN- } \\
650\end{array}$ & - & $\begin{array}{l}\text { Upper } \\
\text { Willa } \\
\text { mette }\end{array}$ & $\begin{array}{c}\text { Baxter and } \\
\text { Connolly }\end{array}$ & 2006 & $7-11$ & $\begin{array}{c}\text { Square } \\
\text { Shovel } \\
\text { Probe } \\
\text { Shovel }\end{array}$ & $1 / 8 "$ & Unlisted & No & No & No & No & No & No & 3.75 & 4.35 \\
\hline 16402 & $\begin{array}{c}\text { 35-LIN- } \\
651\end{array}$ & - & $\begin{array}{c}\text { S. } \\
\text { Santia } \\
\text { m }\end{array}$ & Southard & ND & $4-17$ & $\begin{array}{c}\text { Probe } \\
\text { (square } \\
\text { ) } \\
\text { Shovel }\end{array}$ & $1 / 8^{\prime \prime}$ & Unlisted & No & No & No & No & No & No & 2.5 & 1.79 \\
\hline 16908 & $\begin{array}{c}\text { 35-LIN- } \\
651\end{array}$ & - & $\begin{array}{c}\text { S. } \\
\text { Santia } \\
\mathrm{m} \\
\text { Upper }\end{array}$ & Southard & 1999 & $1-12$ & $\begin{array}{c}\text { Probe } \\
\text { (square } \\
\text { ) }\end{array}$ & $1 / 8^{\prime \prime}$ & Unlisted & No & No & No & No & No & No & 1.75 & 1.05 \\
\hline 260 & $\begin{array}{c}\text { 35-LIN- } \\
659\end{array}$ & - & $\begin{array}{l}\text { Willa } \\
\text { mette } \\
\text { S }\end{array}$ & Southard & 1977 & $1-7$ & $\begin{array}{c}\text { Excava } \\
\text { tion }\end{array}$ & $1 / 4 "$ & Unlisted & No & Yes & No & No & No & No & 1 & .4 \\
\hline 17786 & $\begin{array}{c}\text { 35-LIN- } \\
660\end{array}$ & $\begin{array}{l}\text { Spicer } \\
\text { Drive }\end{array}$ & $\begin{array}{c}\text { Santia } \\
\mathrm{m}\end{array}$ & O'Neill and Jenkins & 2001 & $13-22$ & $\begin{array}{c}\text { Excava } \\
\text { tion } \\
\text { Test } \\
\text { Pit, }\end{array}$ & $1 / 8 "$ & Unlisted & No & Yes & No & No & No & No & 13.75 & 6.6 \\
\hline 18691 & $\begin{array}{c}\text { 35-LIN- } \\
673\end{array}$ & - & $\begin{array}{c}\mathrm{N} . \\
\text { Santia } \\
\mathrm{m}\end{array}$ & Helzer & 2003 & $40-44$ & $\begin{array}{l}\text { Excava } \\
\text { tion, } \\
\text { Auger } \\
\text { Test }\end{array}$ & $1 / 8 "$ & Unlisted & No & No & No & No & $\begin{array}{l}\text { Obsidian } \\
\text { Hydration }\end{array}$ & No & .25 & .1 \\
\hline 18691 & $\begin{array}{c}\text { 35-LIN- } \\
674\end{array}$ & - & $\begin{array}{c}\mathrm{N} . \\
\text { Santia } \\
\mathrm{m}\end{array}$ & Helzer & 2003 & $40-44$ & $\begin{array}{l}\text { Pit, } \\
\text { Excava } \\
\text { tion, } \\
\text { Auger } \\
\text { Test }\end{array}$ & $1 / 8^{\prime \prime}$ & Unlisted & No & No & No & No & $\begin{array}{c}\text { Obsidian } \\
\text { Hydration }\end{array}$ & No & .25 & $\begin{array}{l}\text { Unabl } \\
\text { e to } \\
\text { Deter } \\
\text { mine }\end{array}$ \\
\hline 18691 & $\begin{array}{c}\text { 35-LIN- } \\
675\end{array}$ & - & $\begin{array}{c}\mathrm{N} . \\
\text { Santia } \\
\mathrm{m} \\
\text { Upper }\end{array}$ & Helzer & 2003 & $17-30$ & $\begin{array}{c}\text { Pit, } \\
\text { Excava } \\
\text { tion, } \\
\text { Auger } \\
\text { Square }\end{array}$ & $1 / 8 "$ & Unlisted & No & No & No & No & $\begin{array}{c}\text { Obsidian } \\
\text { Hydration }\end{array}$ & No & 3.75 & $\begin{array}{l}\text { Unabl } \\
\text { e to } \\
\text { Deter } \\
\text { mine }\end{array}$ \\
\hline 20499 & $\begin{array}{c}\text { 35-LIN- } \\
678\end{array}$ & - & $\begin{array}{l}\text { Willa } \\
\text { mette } \\
\text { Upper }\end{array}$ & $\begin{array}{l}\text { Henrickson and } \\
\text { Winterhoff }\end{array}$ & 2005 & $8-10 \backslash$ & $\begin{array}{l}\text { Shovel } \\
\text { Probe } \\
\text { Square }\end{array}$ & $1 / 8 "$ & Unlisted & No & No & No & No & No & No & 4.75 & 2.67 \\
\hline $\begin{array}{l}20499 \\
19494\end{array}$ & $\begin{array}{c}\text { 35-LIN- } \\
679\end{array}$ & - & $\begin{array}{l}\text { Willa } \\
\text { mette }\end{array}$ & $\begin{array}{l}\text { Henrickson and } \\
\text { Winterhoff }\end{array}$ & 2005 & $12-14$ & $\begin{array}{l}\text { Shovel } \\
\text { Probe } \\
\text { Shove }\end{array}$ & $1 / 8^{\prime \prime}$ & Unlisted & No & No & No & No & No & No & .5 & .25 \\
\hline 司 & $\begin{array}{c}\text { 35-LIN- } \\
682\end{array}$ & - & $\begin{array}{l}\text { Upper } \\
\text { Willa } \\
\text { mette }\end{array}$ & Robert R. Munsil & 2005 & $14-27$ & $\begin{array}{c}\text { Test } \\
\text { Probes } \\
\text { and } \\
\text { Shovel } \\
\text { Test }\end{array}$ & $1 / 8 "$ & Unlisted & No & No & No & No & No & No & 5.25 & 2.4 \\
\hline
\end{tabular}




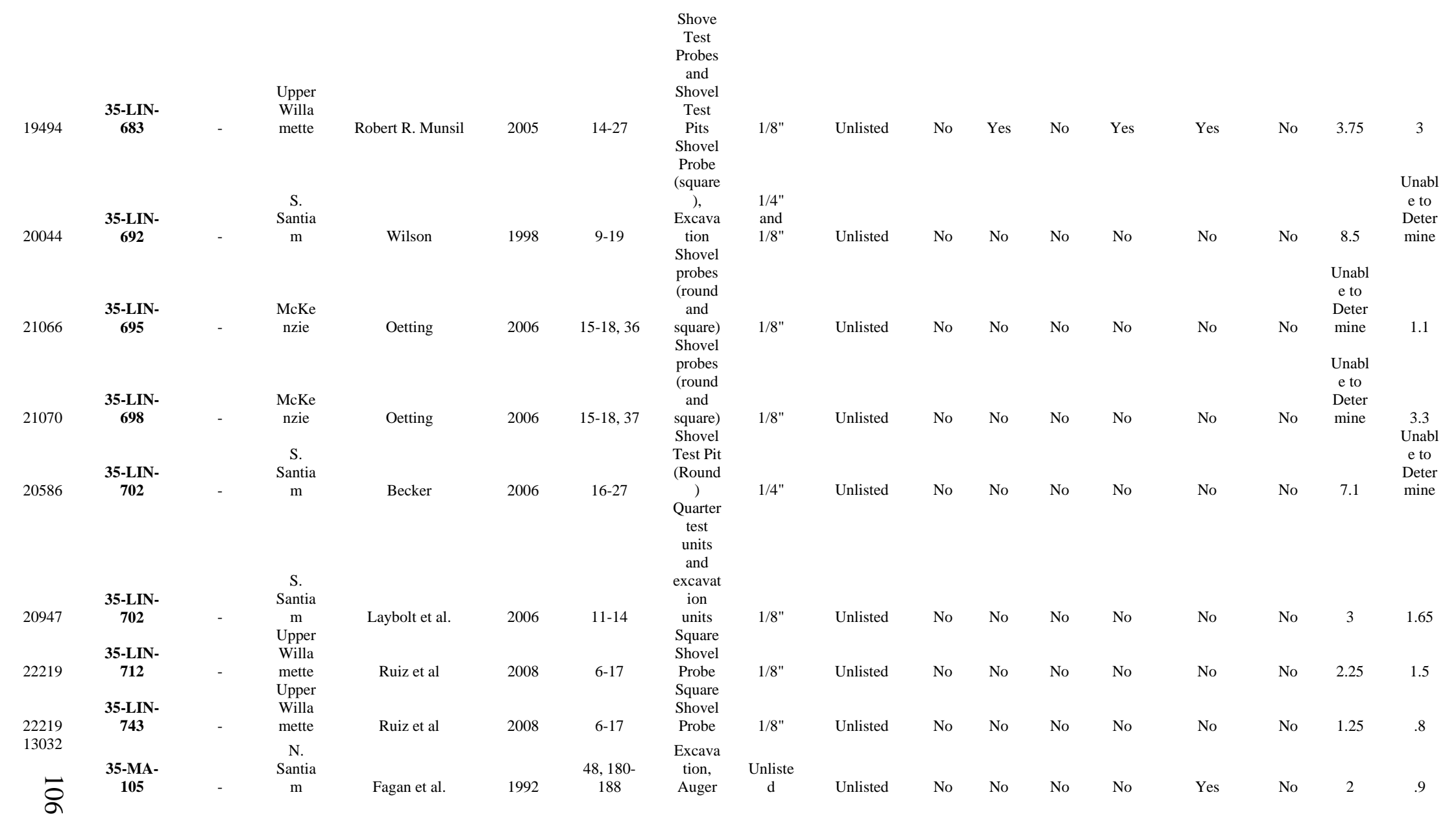




\begin{tabular}{|c|c|c|c|c|c|c|c|c|c|c|c|c|c|c|c|c|c|}
\hline 15608 & $\begin{array}{c}\text { 35-MA- } \\
105\end{array}$ & - & $\begin{array}{c}\mathrm{N} . \\
\text { Santia } \\
\mathrm{m}\end{array}$ & Fagan et al. & 1996 & 4.1-4.47 & $\begin{array}{c}\text { Excava } \\
\text { tion }\end{array}$ & $\begin{array}{l}1 / 4 " \\
\text { and } \\
1 / 8^{\prime \prime}\end{array}$ & Unlisted & No & No & No & Yes & No & No & 23 & $\begin{array}{c}\text { Unlist } \\
\text { ed }\end{array}$ \\
\hline 13032 & $\begin{array}{c}\text { 35-MA- } \\
107\end{array}$ & - & $\begin{array}{l}\text { Mid- } \\
\text { Willa } \\
\text { mette }\end{array}$ & Fagan et al. & 1992 & $\begin{array}{c}48,169- \\
178\end{array}$ & $\begin{array}{c}\text { Excava } \\
\text { tion, } \\
\text { Shovel } \\
\text { Test, } \\
\text { Auger }\end{array}$ & $\begin{array}{c}\text { Unliste } \\
\mathrm{d}\end{array}$ & Unlisted & No & No & No & No & Yes & No & 2.75 & 1.41 \\
\hline
\end{tabular}

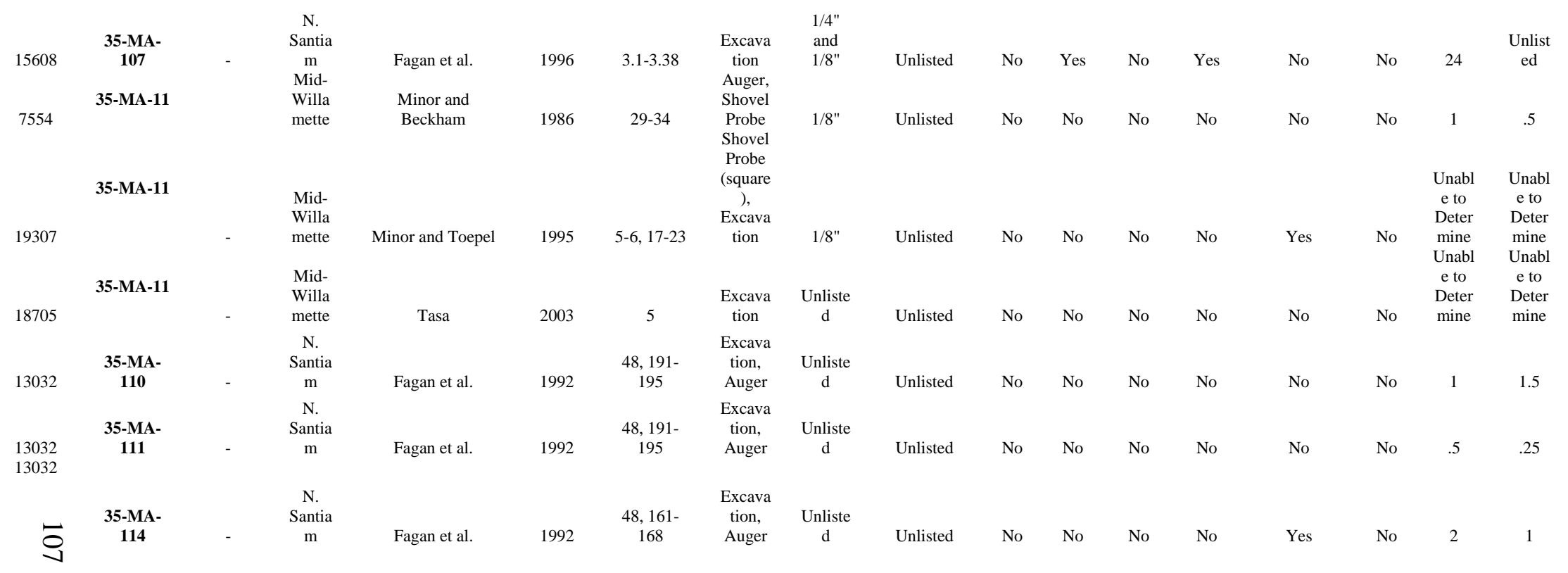




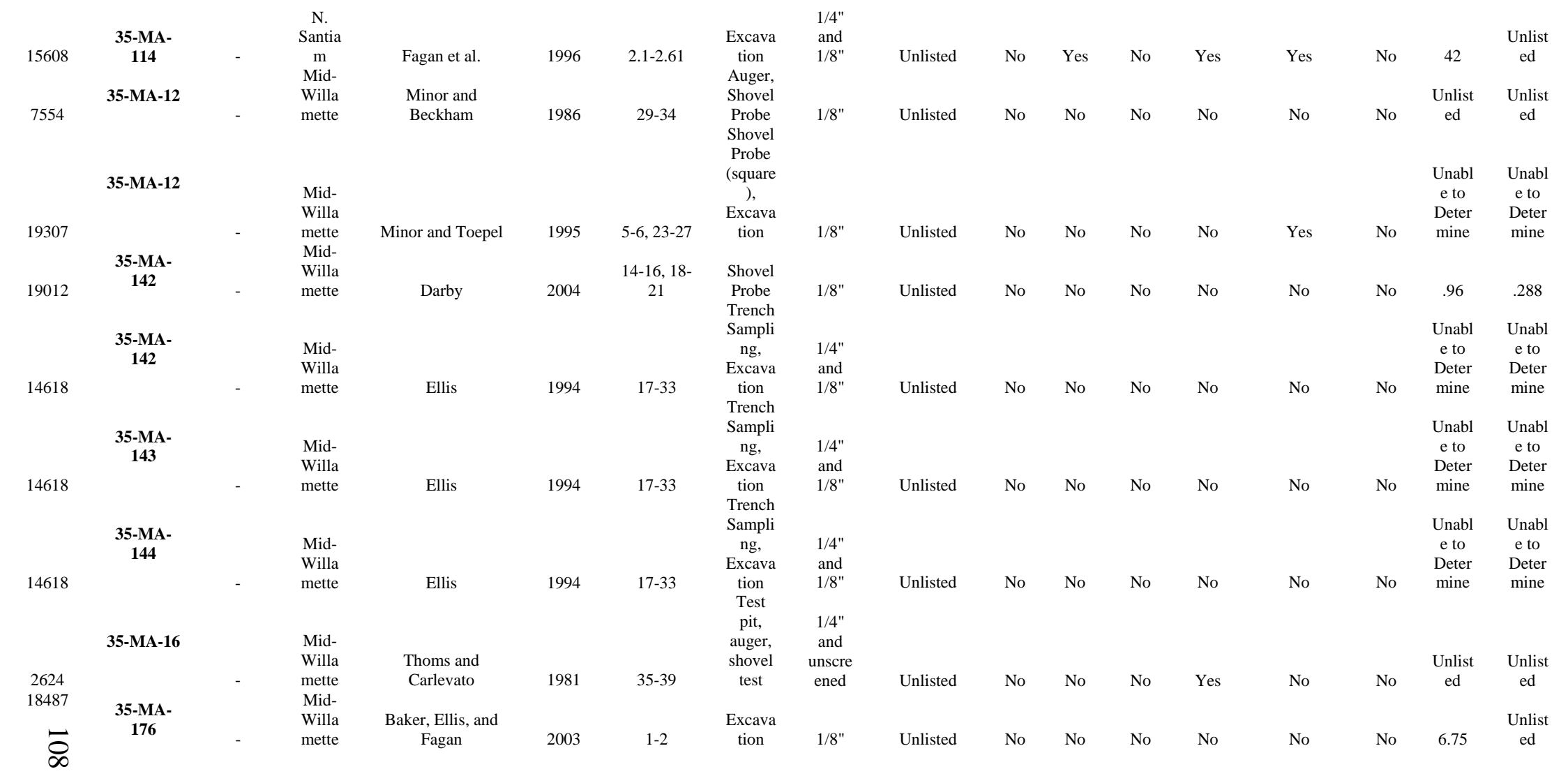




\begin{tabular}{|c|c|c|c|c|c|c|c|c|c|c|c|c|c|c|c|c|c|}
\hline 19117 & $\begin{array}{l}\text { 35-MA- } \\
183\end{array}$ & - & $\begin{array}{l}\text { Mid- } \\
\text { Willa } \\
\text { mette }\end{array}$ & $\begin{array}{l}\text { Fagan, Baker, and } \\
\text { Chapman }\end{array}$ & 2004 & $2-3,4-5$ & $\begin{array}{l}\text { Shovel } \\
\text { test, } \\
\text { quarter } \\
\text { test } \\
\text { units, } \\
\text { and test } \\
\text { units }\end{array}$ & $\begin{array}{l}1 / 4 " \\
\text { and } \\
1 / 8 "\end{array}$ & Unlisted & No & Yes & No & No & No & No & 3.94 & $\begin{array}{c}\text { Unabl } \\
\text { e to } \\
\text { deter } \\
\text { mine }\end{array}$ \\
\hline & & & & & & & $\begin{array}{c}\text { Excava } \\
\text { tion } \\
\text { units } \\
\text { and }\end{array}$ & & & & & & & & & & \\
\hline 19692 & $\begin{array}{c}\text { 35-MA- } \\
183\end{array}$ & - & $\begin{array}{l}\text { Mid- } \\
\text { Willa } \\
\text { mette } \\
\text { Mid- }\end{array}$ & Smits et. Al. & 2004 & $4-15$ & $\begin{array}{c}\text { quarter } \\
\text { test } \\
\text { units }\end{array}$ & $\begin{array}{l}1 / 4 " \\
\text { and } \\
1 / 8 "\end{array}$ & NISP & No & Yes & No & No & No & No & 4.5 & 2.25 \\
\hline 19819 & $\begin{array}{l}\text { 35-MA- } \\
196\end{array}$ & - & $\begin{array}{l}\text { Willa } \\
\text { mette }\end{array}$ & Munsil & 2005 & $2-4$ & $\begin{array}{c}\text { Test } \\
\text { Probes } \\
\text { Shovel }\end{array}$ & 1/8" & Unlisted & No & No & No & No & No & No & 6 & 3 \\
\hline & $\begin{array}{l}\text { 35-MA- } \\
197\end{array}$ & & $\begin{array}{l}\text { Mid- } \\
\text { Willa }\end{array}$ & & & & $\begin{array}{l}\text { Probe } \\
\text { (round } \\
\text { and }\end{array}$ & & & & & & & & & & Unlist \\
\hline 20431 & 35-MA- & - & $\begin{array}{c}\text { mette } \\
\text { N. } \\
\text { Santia }\end{array}$ & Munsil & 2006 & & $\begin{array}{l}\text { square) } \\
\text { Test Pit } \\
\text { (50x50 }\end{array}$ & 1/8" & Unlisted & No & No & No & No & No & No & 3.93 & ed \\
\hline 19985 & 217 & - & $\mathrm{m}$ & Kelly & 2005 & $2-9$ & $\begin{array}{c}\text { ) } \\
\text { Shovel } \\
\text { Probes }\end{array}$ & $1 / 8^{\prime \prime}$ & Unlisted & No & No & No & No & No & No & 1.5 & .675 \\
\hline 12626 & 35-MA-22 & - & $\begin{array}{c}\text { N. } \\
\text { Santia } \\
\mathrm{m}\end{array}$ & $\begin{array}{l}\text { Churchill and } \\
\text { Jenkins }\end{array}$ & 1991 & $19-42$ & $\begin{array}{l}\text { and } \\
\text { Excava } \\
\text { tion }\end{array}$ & $\begin{array}{l}1 / 4 " \\
\text { and } \\
1 / 8 "\end{array}$ & Unlisted & No & No & No & No & No & No & 11 & $\begin{array}{l}\text { Unlist } \\
\text { ed }\end{array}$ \\
\hline 20296 & $\begin{array}{c}\text { 35-MA- } \\
222\end{array}$ & - & $\begin{array}{l}\text { Mid- } \\
\text { Willa } \\
\text { mette }\end{array}$ & Tasa and Knowles & 2005 & 3-5 & $\begin{array}{l}\text { Shovel } \\
\text { tests }\end{array}$ & $1 / 8 "$ & Unlisted & No & Yes & No & No & No & No & $\begin{array}{l}\text { Unlist } \\
\text { ed }\end{array}$ & $\begin{array}{l}.297 \\
\text { Unabl }\end{array}$ \\
\hline 5659 & 35-MA-48 & - & $\begin{array}{c}\mathrm{N} . \\
\text { Santia } \\
\mathrm{m}\end{array}$ & $\begin{array}{l}\text { Jenkins and } \\
\text { Churchill }\end{array}$ & 1984 & 5-8 & $\begin{array}{c}\text { Excava } \\
\text { tion } \\
\text { Trench }\end{array}$ & $1 / 4 "$ & Unlisted & No & No & No & No & No & No & 6 & $\begin{array}{l}\text { e to } \\
\text { deter } \\
\text { mine }\end{array}$ \\
\hline $\begin{array}{l}11663 \\
4011\end{array}$ & 35-MA-49 & - & $\begin{array}{c}\text { N. } \\
\text { Santia } \\
\text { m }\end{array}$ & Beardsley & 1990 & $8-26$ & $\begin{array}{c}\text { and } \\
\text { Excava } \\
\text { tion }\end{array}$ & $\begin{array}{c}1 / 8 " \\
\text { and } \\
1 / 16 "\end{array}$ & Unlisted & No & No & No & No & No & No & 21.5 & $\begin{array}{c}5.4 \\
\text { Unabl }\end{array}$ \\
\hline ஜ & 35-MA-51 & - & $\begin{array}{c}\mathrm{N} . \\
\text { Santia } \\
\mathrm{m}\end{array}$ & Regula & 1982 & 3-5 & $\begin{array}{c}\text { Shovel } \\
\text { Test }\end{array}$ & $\begin{array}{l}\text { Unliste } \\
\mathrm{d}\end{array}$ & Unlisted & No & No & No & No & No & No & 6 & $\begin{array}{l}\text { e to } \\
\text { deter } \\
\text { mine }\end{array}$ \\
\hline
\end{tabular}




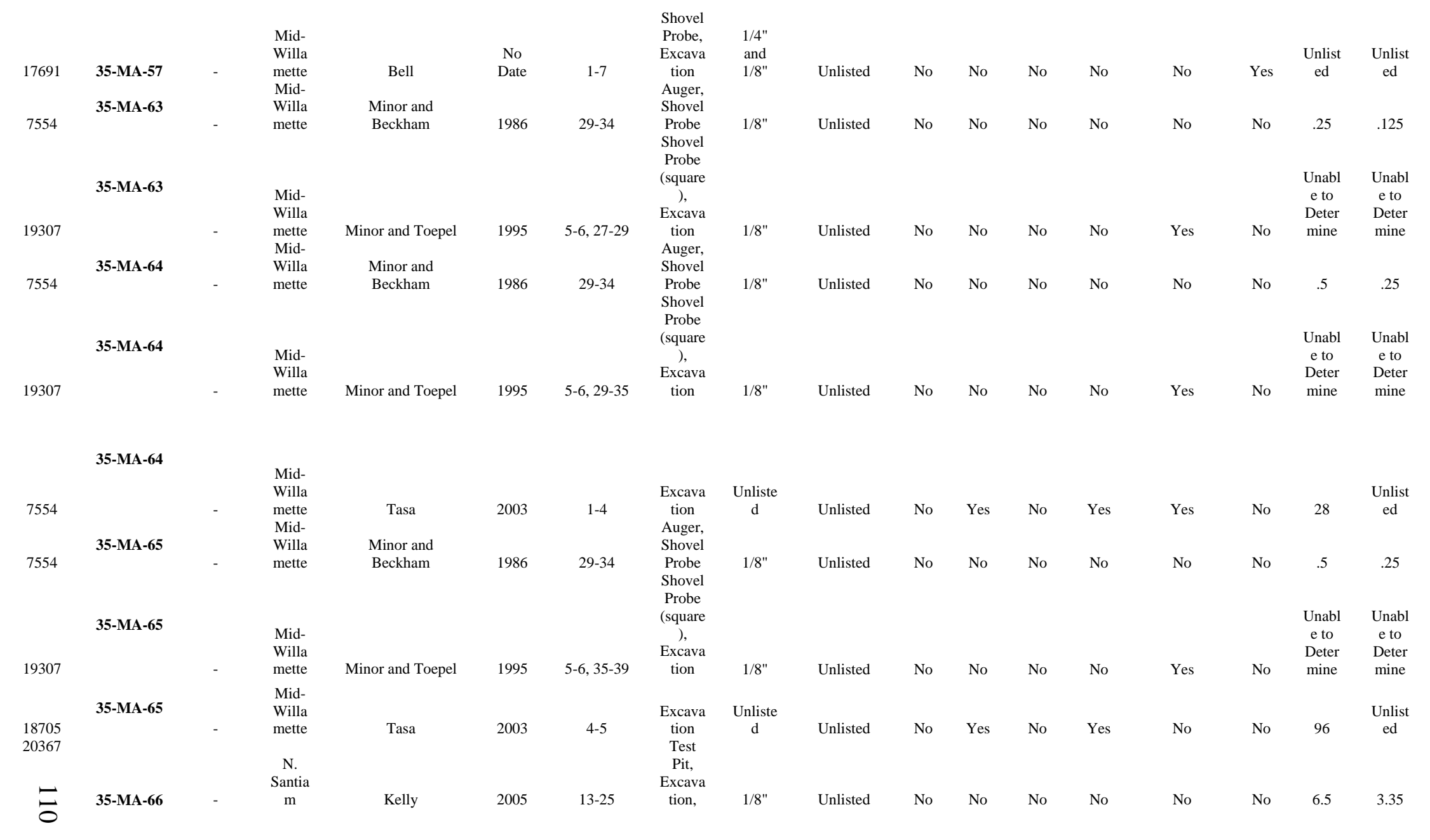




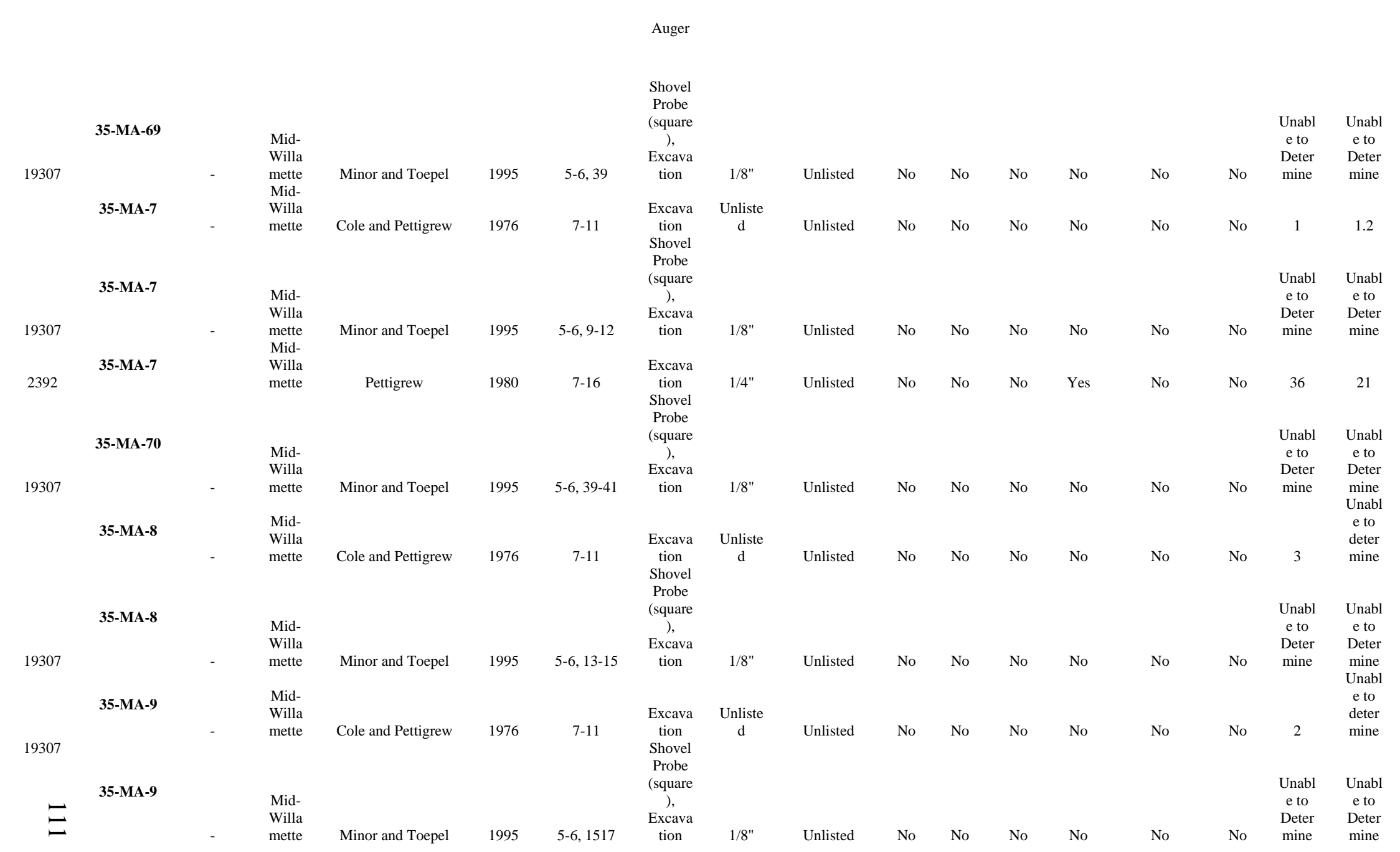




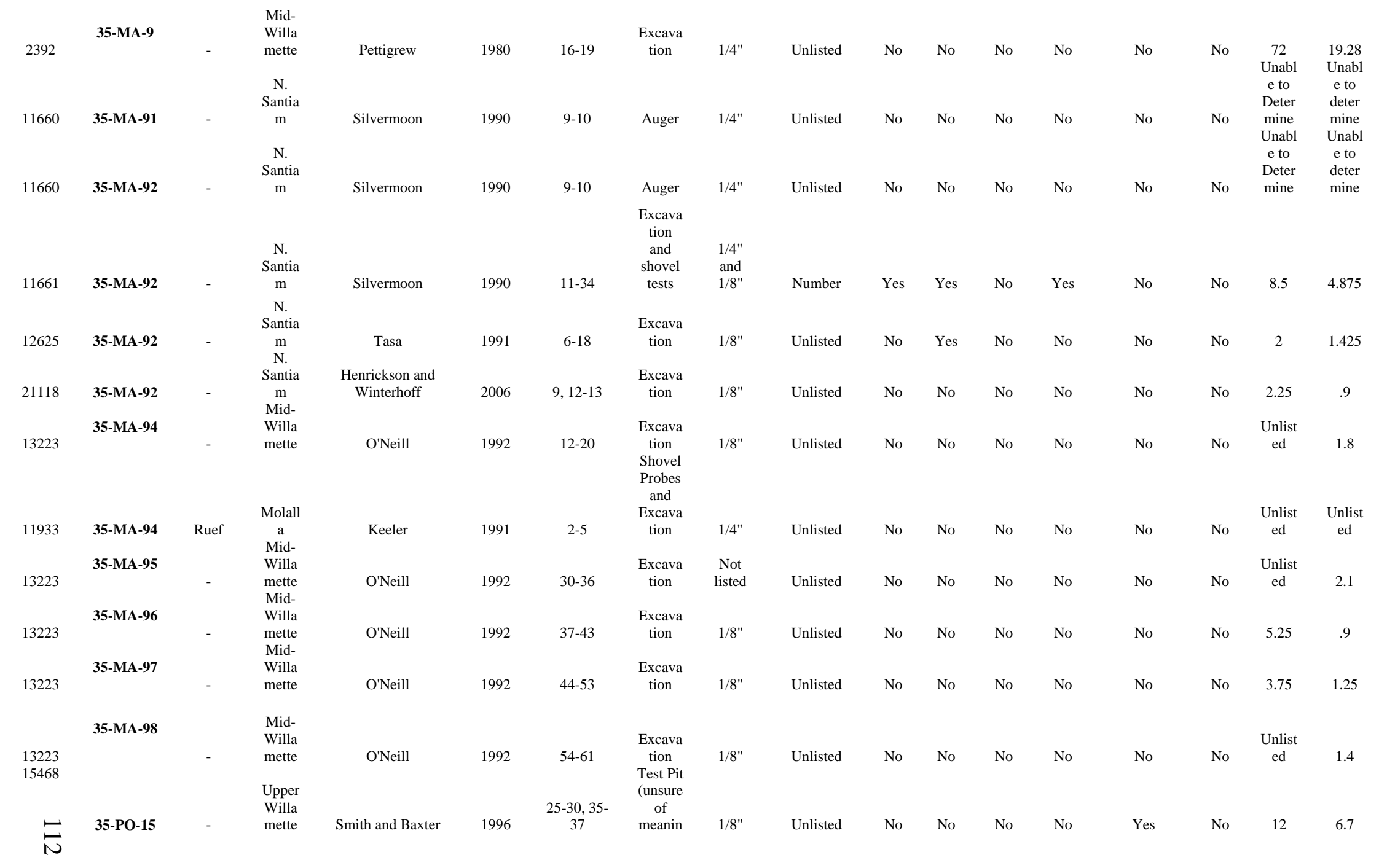




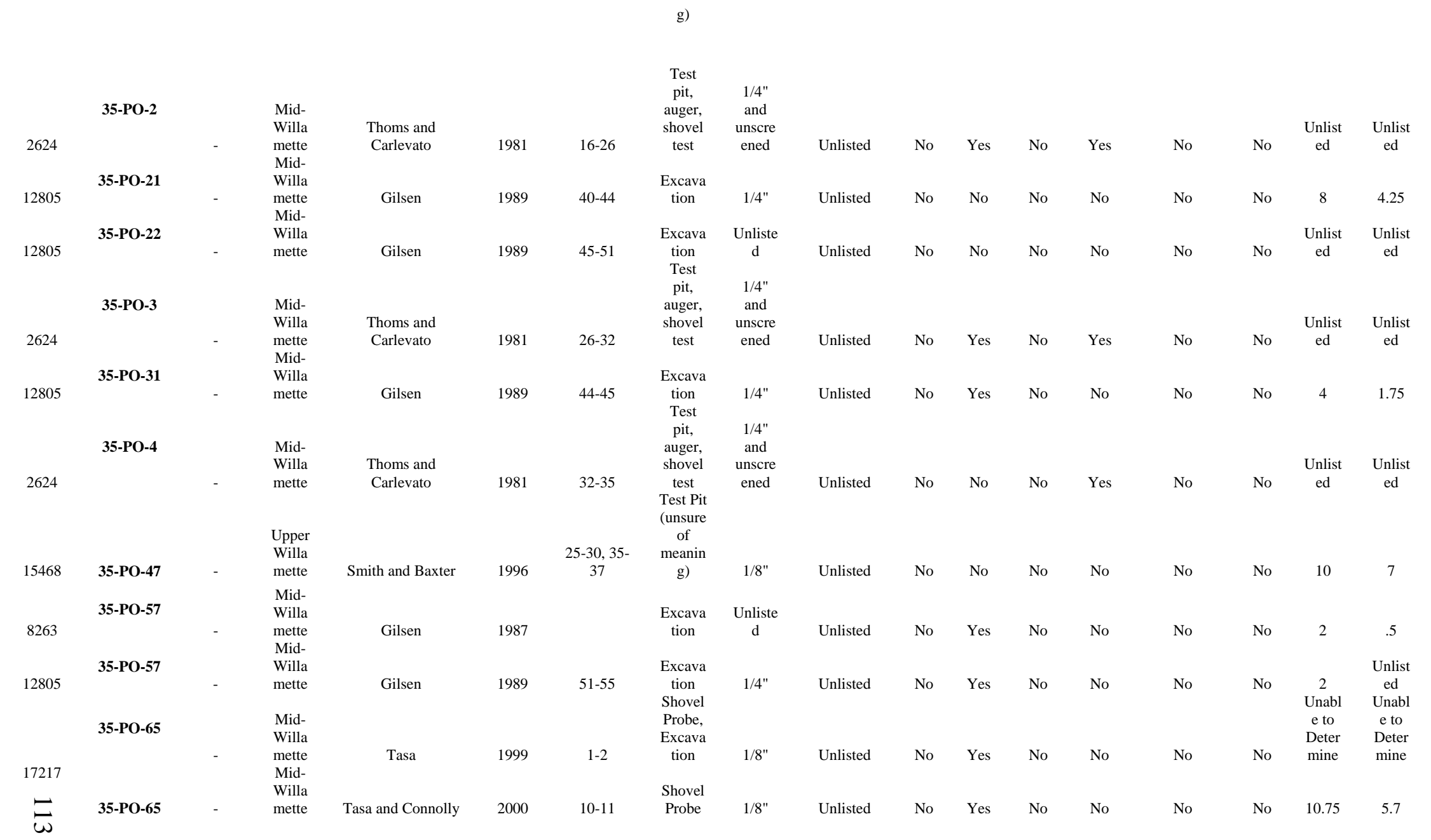




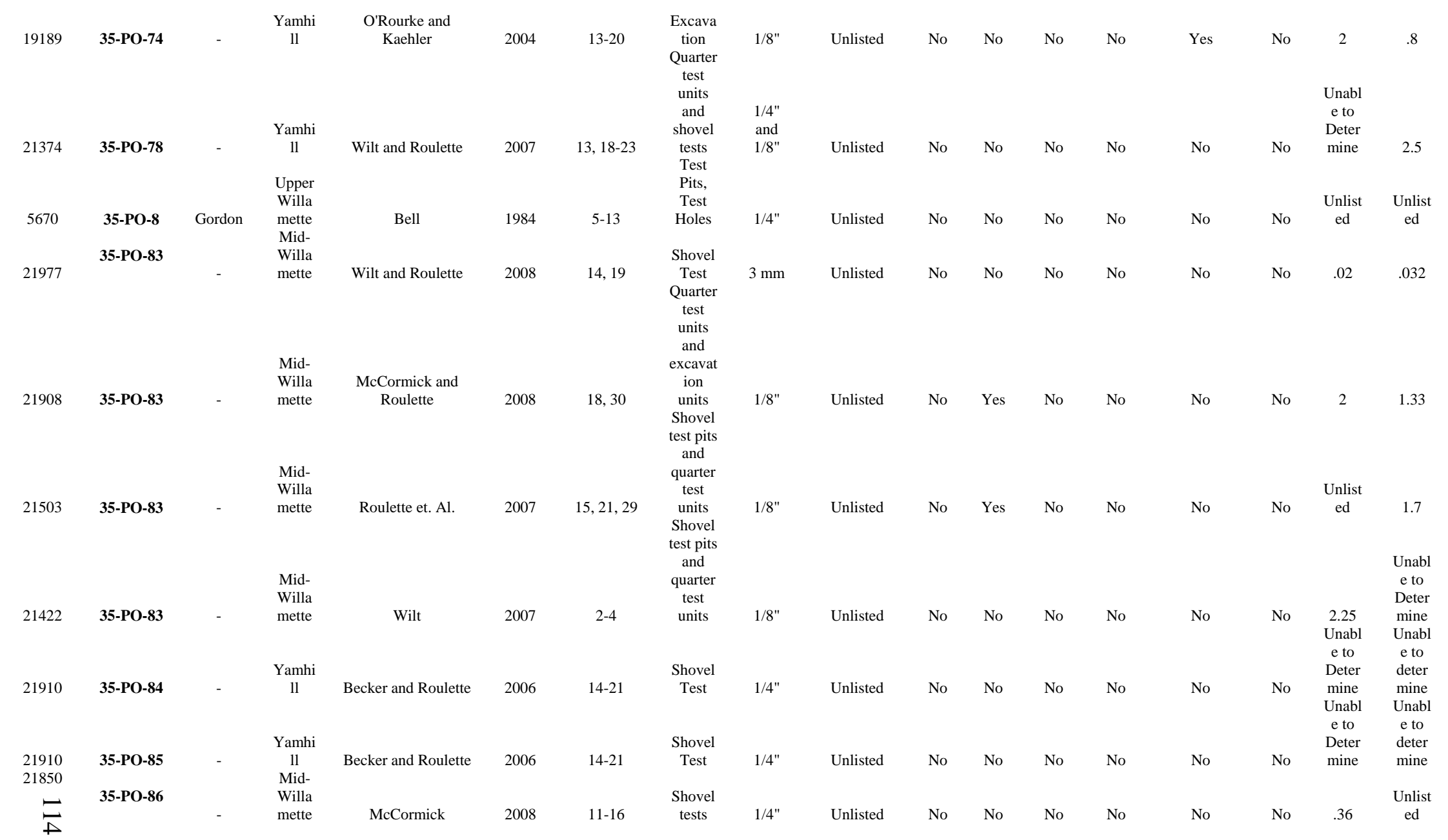




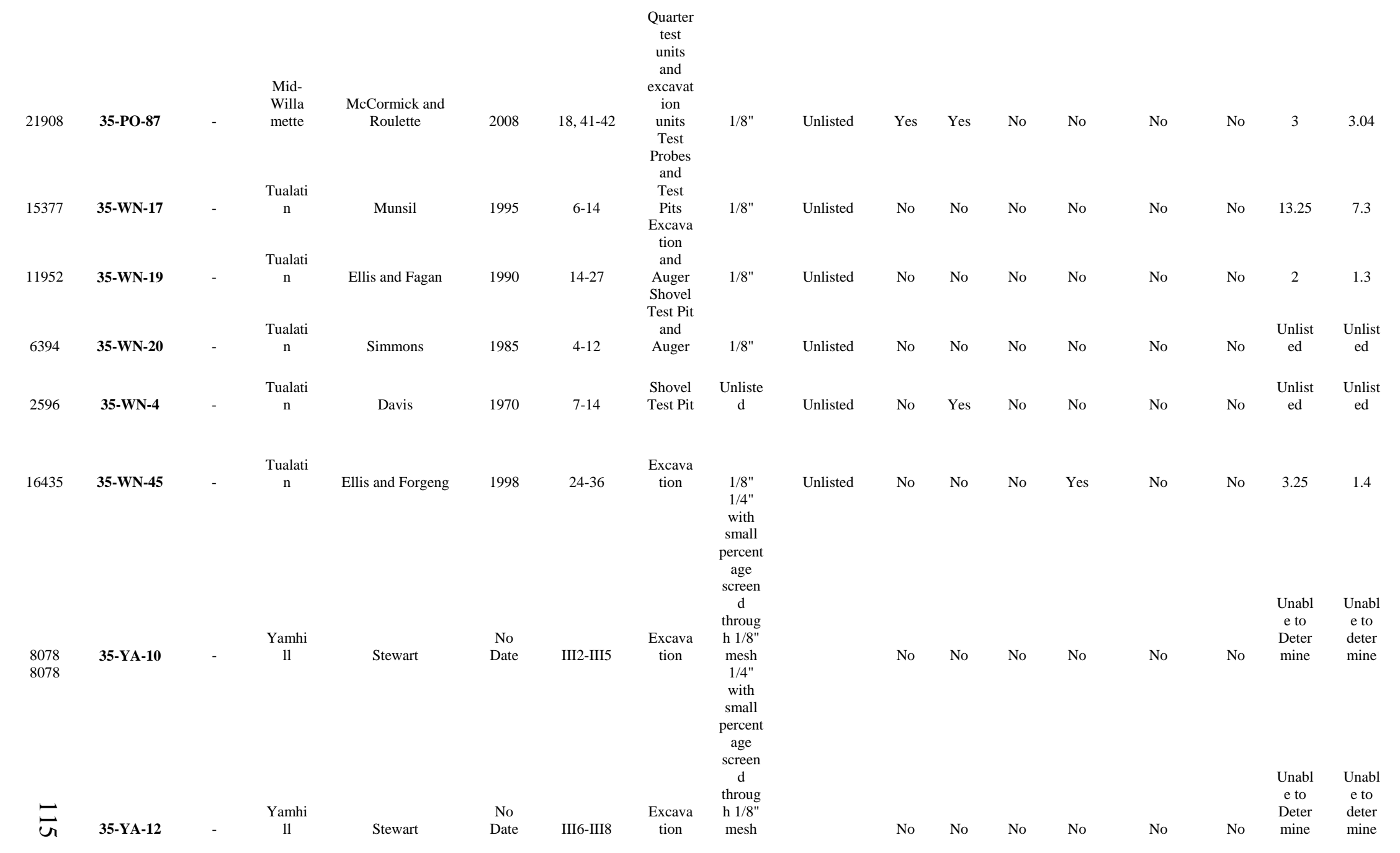




\begin{tabular}{|c|c|c|c|c|c|c|c|c|c|c|c|c|c|c|c|c|c|}
\hline 21977 & 679-1 & - & $\begin{array}{l}\text { Mid- } \\
\text { Willa } \\
\text { mette }\end{array}$ & Wilt and Roulette & 2008 & $\begin{array}{c}14,20,25- \\
28\end{array}$ & $\begin{array}{c}\text { Shovel } \\
\text { Test }\end{array}$ & $3 \mathrm{~mm}$ & Unlisted & No & Yes & No & No & No & No & .013 & .02 \\
\hline 21977 & 679-2 & - & $\begin{array}{l}\text { MMld- } \\
\text { Willa } \\
\text { mette }\end{array}$ & Wilt and Roulette & 2008 & $\begin{array}{c}14,20,28- \\
29\end{array}$ & $\begin{array}{c}\text { Shovel } \\
\text { Test }\end{array}$ & $3 \mathrm{~mm}$ & Unlisted & No & No & No & No & No & No & .025 & .05 \\
\hline 21977 & 679-3 & - & $\begin{array}{l}\text { Mid- } \\
\text { Willa } \\
\text { mette }\end{array}$ & Roulette and Wilt & 2008 & $\begin{array}{c}14,20,29- \\
34\end{array}$ & $\begin{array}{l}\text { Shovel } \\
\text { Test }\end{array}$ & $3 \mathrm{~mm}$ & Unlisted & No & Yes & No & No & No & No & $\begin{array}{l}.01 \\
\text { Unabl } \\
\text { e to }\end{array}$ & $\begin{array}{c}.02 \\
\text { Unabl } \\
\text { e to }\end{array}$ \\
\hline 21971 & $\begin{array}{c}\text { AAR 702- } \\
1\end{array}$ & - & $\begin{array}{c}\text { Yamhi } \\
\text { ll }\end{array}$ & Becker et. Al. & 2008 & $14,24-41$ & $\begin{array}{c}\text { Shovel } \\
\text { Test }\end{array}$ & 1/8" & Unlisted & No & No & No & No & No & No & $\begin{array}{c}\text { Deter } \\
\text { mine } \\
\text { Unabl } \\
\text { e to }\end{array}$ & $\begin{array}{l}\text { Deter } \\
\text { mine } \\
\text { Unabl } \\
\text { e to }\end{array}$ \\
\hline 21971 & $\begin{array}{c}\text { AAR 702- } \\
2\end{array}$ & - & $\begin{array}{c}\text { Yamhi } \\
\text { ll }\end{array}$ & Becker et. Al. & 2008 & $14,24-41$ & $\begin{array}{c}\text { Shovel } \\
\text { Test }\end{array}$ & $1 / 8 "$ & Unlisted & No & No & No & No & No & No & $\begin{array}{c}\text { Deter } \\
\text { mine } \\
\text { Unabl } \\
\text { e to }\end{array}$ & $\begin{array}{c}\text { Deter } \\
\text { mine } \\
\text { Unabl } \\
\text { e to }\end{array}$ \\
\hline 21971 & $\begin{array}{c}\text { AAR 702- } \\
3\end{array}$ & - & $\begin{array}{c}\text { Yamhi } \\
\text { ll }\end{array}$ & Becker et. Al. & 2008 & $14,24-41$ & $\begin{array}{c}\text { Shovel } \\
\text { Test } \\
\text { Shovel } \\
\text { Probe }\end{array}$ & $1 / 8 "$ & Unlisted & No & No & No & No & No & No & $\begin{array}{l}\text { Deter } \\
\text { mine } \\
\text { Unabl } \\
\text { e to }\end{array}$ & $\begin{array}{c}\text { Deter } \\
\text { mine } \\
\text { Unabl } \\
\text { e to }\end{array}$ \\
\hline 11943 & JS-1 & - & $\begin{array}{l}\text { Mid- } \\
\text { Willa } \\
\text { mette } \\
\text { Mid- }\end{array}$ & O'Neill & 1990 & $1-3$ & $\begin{array}{c}\text { (square } \\
\text { ) }\end{array}$ & 1/8" & Unlisted & No & No & No & No & No & No & $\begin{array}{l}\text { e to } \\
\text { Deter } \\
\text { mine }\end{array}$ & Deter \\
\hline 13223 & JS-2 & - & $\begin{array}{l}\text { Willa } \\
\text { mette }\end{array}$ & O'Neill & 1992 & $21-25$ & $\begin{array}{c}\text { Excava } \\
\text { tion } \\
\text { Shovel }\end{array}$ & $1 / 8 "$ & Unlisted & No & No & No & No & No & No & $\begin{array}{l}\text { Unlist } \\
\text { ed }\end{array}$ & 1 \\
\hline & JS-2 & & $\begin{array}{l}\text { Mid- } \\
\text { Willa }\end{array}$ & & & & $\begin{array}{l}\text { Probe } \\
\text { (square }\end{array}$ & & & & & & & & & & \\
\hline 11943 & & - & $\begin{array}{l}\text { mette } \\
\text { Mid- }\end{array}$ & O'Neill & 1990 & $1,3-4$ & ) & $1 / 8^{\prime \prime}$ & Unlisted & No & No & No & No & No & No & 1.5 & 1.2 \\
\hline 13223 & JS-3 & - & $\begin{array}{l}\text { Willa } \\
\text { mette }\end{array}$ & O'Neill & 1992 & $26-29$ & $\begin{array}{c}\text { Excava } \\
\text { tion } \\
\text { Shovel }\end{array}$ & $1 / 8 "$ & Unlisted & No & No & No & No & No & No & $\begin{array}{l}\text { Unlist } \\
\text { ed }\end{array}$ & .65 \\
\hline & JS-3 & & $\begin{array}{l}\text { Mid- } \\
\text { Willa }\end{array}$ & & & & $\begin{array}{l}\text { Probe } \\
\text { (square }\end{array}$ & & & & & & & & & & \\
\hline 11943 & & - & mette & O'Neill & 1990 & 1,4 & $\begin{array}{c}\text { ) } \\
\text { Shovel }\end{array}$ & $1 / 8 "$ & Unlisted & No & No & No & No & No & No & .75 & .375 \\
\hline & JS-4 & & $\begin{array}{l}\text { Mid- } \\
\text { Willa }\end{array}$ & & & & $\begin{array}{l}\text { Probe } \\
\text { (square }\end{array}$ & & & & & & & & & & \\
\hline $\begin{array}{l}11943 \\
11943\end{array}$ & & - & mette & O'Neill & 1990 & 1,4 & $\begin{array}{c}\text { ) } \\
\text { Shovel }\end{array}$ & 1/8" & Unlisted & No & No & No & No & No & No & 2 & 1.2 \\
\hline 皇 & JS-5 & - & $\begin{array}{l}\text { Mid- } \\
\text { Willa } \\
\text { mette }\end{array}$ & O'Neill & 1990 & 1,5 & $\begin{array}{c}\text { Probe } \\
\text { (square } \\
\quad \text { ) }\end{array}$ & 1/8" & Unlisted & No & No & No & No & No & No & 5.25 & 3.15 \\
\hline
\end{tabular}




\begin{tabular}{|c|c|c|c|c|c|c|c|c|c|c|c|c|c|c|c|c|c|}
\hline 11943 & JS-6 & - & $\begin{array}{l}\text { Mid- } \\
\text { Willa } \\
\text { mette }\end{array}$ & O'Neill & 1990 & $1,6-8$ & $\begin{array}{c}\text { Shovel } \\
\text { Probe } \\
\text { (square } \\
\text { ) }\end{array}$ & $1 / 8 "$ & Unlisted & No & No & No & No & No & No & $\begin{array}{l}\text { Unabl } \\
\text { e to } \\
\text { Deter } \\
\text { mine }\end{array}$ & $\begin{array}{l}\text { Unabl } \\
\text { e to } \\
\text { Deter } \\
\text { mine }\end{array}$ \\
\hline & JS-7 & & $\begin{array}{l}\text { Mid- } \\
\text { Willa }\end{array}$ & & & & $\begin{array}{l}\text { Shovel } \\
\text { Probe } \\
\text { (square }\end{array}$ & & & & & & & & & & \\
\hline 11943 & & - & $\begin{array}{l}\text { mette } \\
\text { Mid- }\end{array}$ & O'Neill & 1990 & 1,8 & ) & $1 / 8 "$ & Unlisted & No & No & No & No & No & No & 2.75 & .63 \\
\hline 21757 & Unnamed & - & $\begin{array}{l}\text { Willa } \\
\text { mette } \\
\text { Mid- }\end{array}$ & Becker and Roulette & 2008 & 13 & $\begin{array}{c}\text { Shovel } \\
\text { Tests }\end{array}$ & $1 / 8^{\prime \prime}$ & Unlisted & No & No & No & No & No & No & .66 & $\begin{array}{l}\text { Unlist } \\
\text { ed }\end{array}$ \\
\hline 22068 & Unnamed & $\begin{array}{l}\text { AAR74 } \\
5-1\end{array}$ & $\begin{array}{l}\text { Willa } \\
\text { mette }\end{array}$ & $\begin{array}{l}\text { Roulette and } \\
\text { Lehman }\end{array}$ & 2008 & $15-23$ & $\begin{array}{c}\text { Shovel } \\
\text { tests }\end{array}$ & $1 / 4^{\prime \prime}$ & Unlisted & No & No & No & No & No & No & $\begin{array}{c}1 \\
\text { Unabl }\end{array}$ & $\begin{array}{l}\text { Unlist } \\
\text { ed } \\
\text { Unabl }\end{array}$ \\
\hline 13617 & - & $\begin{array}{c}\text { Jory } \\
\text { Cemetar } \\
\text { y }\end{array}$ & $\begin{array}{l}\text { Mid- } \\
\text { Willa } \\
\text { mette }\end{array}$ & Armitage & 1993 & $10-12$ & $\begin{array}{c}\text { Shovel } \\
\text { Probe }\end{array}$ & $\begin{array}{l}\text { Unliste } \\
\mathrm{d}\end{array}$ & Unlisted & No & No & No & No & No & No & $\begin{array}{l}\text { e to } \\
\text { Deter } \\
\text { mine } \\
\text { Unabl }\end{array}$ & $\begin{array}{l}\text { e to } \\
\text { Deter } \\
\text { mine } \\
\text { Unabl }\end{array}$ \\
\hline 16766 & - & $\begin{array}{l}\text { Lockma } \\
\text { sters } \\
\text { Office }\end{array}$ & $\begin{array}{l}\text { Mid- } \\
\text { Willa } \\
\text { mette }\end{array}$ & $\begin{array}{l}\text { Minor, Musil, and } \\
\text { Sprague }\end{array}$ & 1992 & 7,32 & $\begin{array}{c}\text { Excava } \\
\text { tion } \\
\text { Excava } \\
\text { tion } \\
\text { and }\end{array}$ & $1 / 8^{\prime \prime}$ & Unlisted & No & No & No & No & No & Yes & $\begin{array}{l}\text { e to } \\
\text { Deter } \\
\text { mine }\end{array}$ & $\begin{array}{l}\text { e to } \\
\text { Deter } \\
\text { mine }\end{array}$ \\
\hline 8077 & - & $\begin{array}{l}\text { Evans } \\
\text { Site } 1\end{array}$ & $\begin{array}{c}\text { Yamhi } \\
\text { ll }\end{array}$ & Stewart & $\begin{array}{l}\text { No } \\
\text { Date }\end{array}$ & A13-A34 & $\begin{array}{l}\text { shovel } \\
\text { tests } \\
\text { Excava } \\
\text { tion } \\
\text { and }\end{array}$ & $\begin{array}{l}\text { Unliste } \\
\mathrm{d}\end{array}$ & Unlisted & No & No & No & No & No & No & $\begin{array}{l}\text { Unlist } \\
\text { ed }\end{array}$ & $\begin{array}{l}\text { Unlist } \\
\text { ed }\end{array}$ \\
\hline 8077 & - & $\begin{array}{l}\text { Evans } \\
\text { Site } 2\end{array}$ & $\begin{array}{l}\text { Yamhi } \\
\text { ll }\end{array}$ & Stewart & $\begin{array}{l}\text { No } \\
\text { Date }\end{array}$ & A13-A34 & $\begin{array}{l}\text { shovel } \\
\text { tests } \\
\text { Excava } \\
\text { tion } \\
\text { and }\end{array}$ & $\begin{array}{l}\text { Unliste } \\
\mathrm{d}\end{array}$ & Unlisted & No & No & No & No & No & No & $\begin{array}{l}\text { Unlist } \\
\text { ed }\end{array}$ & $\begin{array}{l}\text { Unlist } \\
\text { ed }\end{array}$ \\
\hline 8077 & - & $\begin{array}{l}\text { Evans } \\
\text { Site } 3\end{array}$ & $\begin{array}{l}\text { Yamhi } \\
\text { ll }\end{array}$ & Stewart & $\begin{array}{l}\text { No } \\
\text { Date }\end{array}$ & A13-A34 & $\begin{array}{l}\text { shovel } \\
\text { tests } \\
\text { Excava } \\
\text { tion } \\
\text { and }\end{array}$ & $\begin{array}{l}\text { Unliste } \\
\mathrm{d}\end{array}$ & Unlisted & No & No & No & No & No & No & $\begin{array}{l}\text { Unlist } \\
\text { ed }\end{array}$ & $\begin{array}{l}\text { Unlist } \\
\text { ed }\end{array}$ \\
\hline 8077 & - & $\begin{array}{l}\text { Evans } \\
\text { Site } 4\end{array}$ & $\begin{array}{l}\text { Yamhi } \\
\text { ll }\end{array}$ & Stewart & $\begin{array}{l}\text { No } \\
\text { Date }\end{array}$ & A13-A34 & $\begin{array}{l}\text { shovel } \\
\text { tests } \\
\text { Excava } \\
\text { tion } \\
\text { and }\end{array}$ & $\begin{array}{l}\text { Unliste } \\
\mathrm{d}\end{array}$ & Unlisted & No & No & No & No & No & No & $\begin{array}{l}\text { Unlist } \\
\text { ed }\end{array}$ & $\begin{array}{l}\text { Unlist } \\
\text { ed }\end{array}$ \\
\hline 8077 & - & $\begin{array}{l}\text { Wilkes } \\
\text { Site } 7\end{array}$ & $\begin{array}{l}\text { Yamhi } \\
\text { ll }\end{array}$ & Stewart & $\begin{array}{l}\text { No } \\
\text { Date }\end{array}$ & A13-A34 & $\begin{array}{l}\text { shovel } \\
\text { tests }\end{array}$ & $\begin{array}{c}\text { Unliste } \\
\mathrm{d}\end{array}$ & Unlisted & No & No & No & No & No & No & $\begin{array}{l}\text { Unlist } \\
\text { ed }\end{array}$ & $\begin{array}{l}\text { Unlist } \\
\text { ed }\end{array}$ \\
\hline
\end{tabular}


Appendix B. Summary Table of Resource Return Rates in the Willamette Valley 


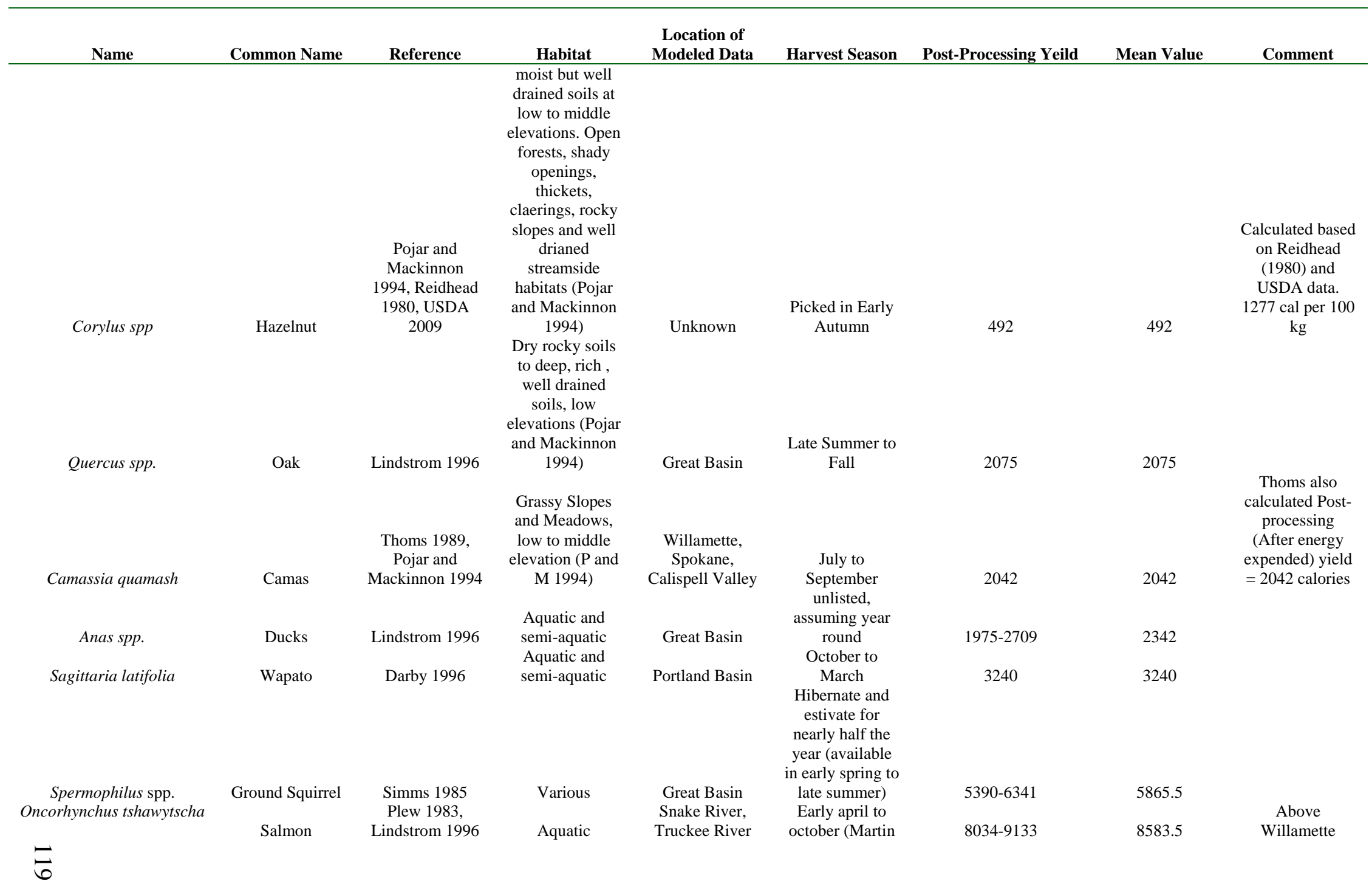




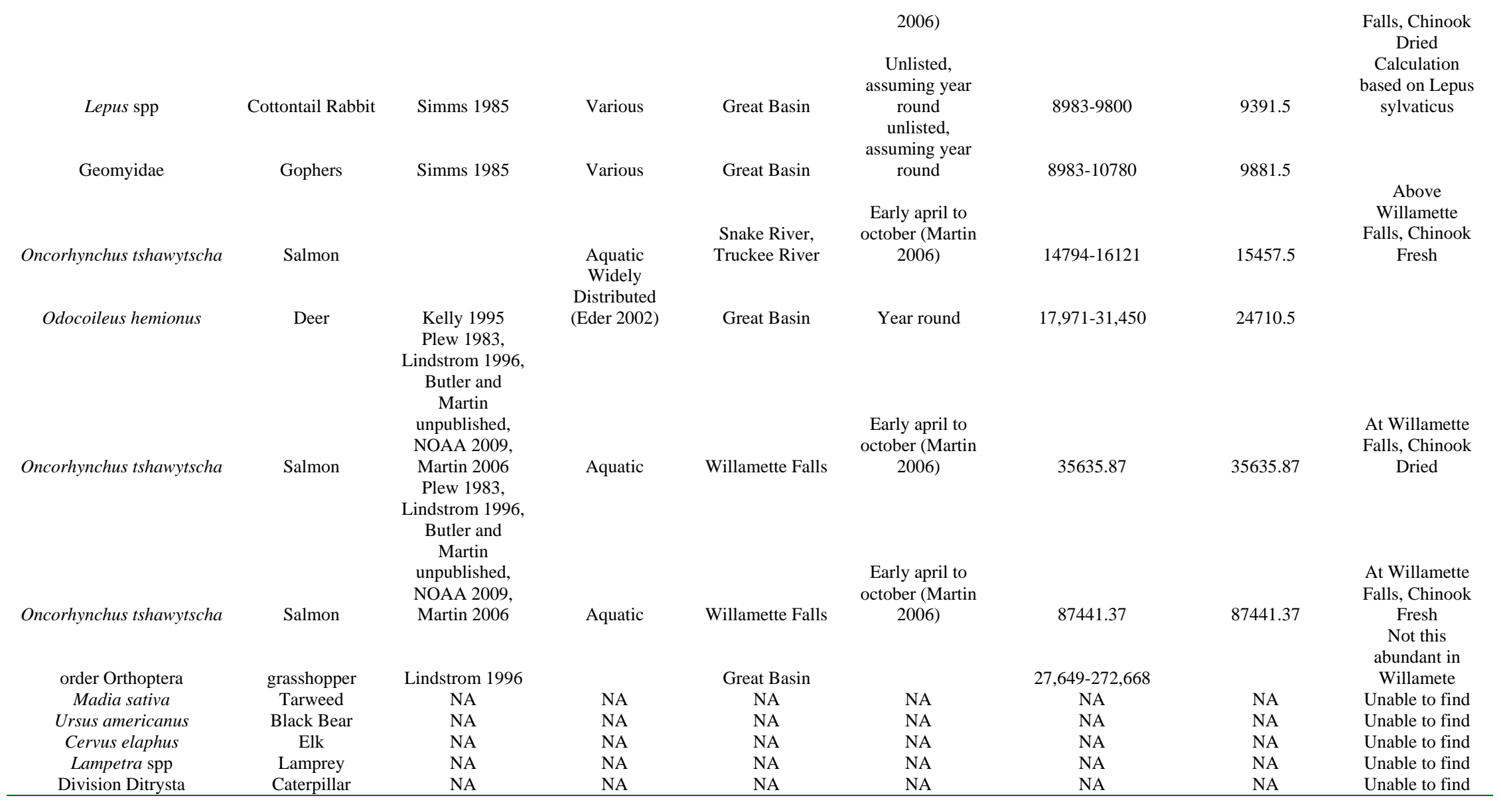


Appendix C. Hazelnut OFM Calculations

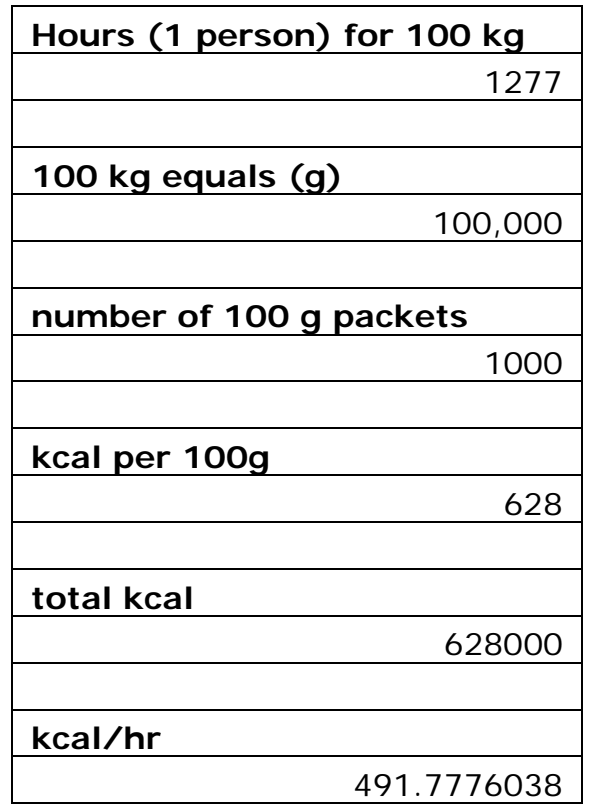


Appendix D. Chinook Salmon Return Rates at Willamette Falls

\begin{tabular}{|c|c|c|c|c|c|}
\hline $\begin{array}{l}\text { Number } \\
\text { of } \\
\text { people }\end{array}$ & \multicolumn{2}{|l|}{ Number of Hours } & \multicolumn{2}{|l|}{ Salmon per hour } & $\begin{array}{l}\text { Mean } \\
\text { adult } \\
\text { weight } \\
(\mathrm{kg})\end{array}$ \\
\hline \multirow[t]{22}{*}{1} & & 12 & & 20 & 13.61 \\
\hline & \multicolumn{2}{|l|}{ Salmon per day } & \multicolumn{2}{|c|}{ Salmon weight per day ( $k g)$} & \\
\hline & & 240 & & 3266.4 & \\
\hline & \multicolumn{2}{|c|}{ Kcal per $100 \mathrm{~g}$ smoked } & \multicolumn{2}{|l|}{ Kcal per $100 \mathrm{~g}$ fresh } & \\
\hline & & 176 & & 222 & \\
\hline & \multicolumn{2}{|c|}{$\begin{array}{l}\text { Kcal per kg smoked (100g x } \\
\text { 10) }\end{array}$} & \multicolumn{2}{|c|}{$\begin{array}{l}\text { Kcal per go fresh }(\operatorname{lo0g} x \\
\text { 10) }\end{array}$} & \\
\hline & \multicolumn{2}{|r|}{1760} & \multicolumn{2}{|r|}{2220} & \\
\hline & \multicolumn{2}{|c|}{ Total calories smoked } & \multicolumn{2}{|l|}{ Total Calories fresh } & \\
\hline & \multicolumn{2}{|r|}{5748864} & \multicolumn{2}{|c|}{7251408} & \\
\hline & \multicolumn{2}{|c|}{$\begin{array}{l}\text { Smoked handling ratio } \\
\text { ( hr/ kg) }\end{array}$} & \multicolumn{2}{|c|}{$\begin{array}{l}\text { I mmedate consumption } \\
\text { handling ratio ( } \mathrm{hr} / \mathrm{kg} \text { ) }\end{array}$} & \\
\hline & \multicolumn{2}{|l|}{$0.024-0.058$} & \multicolumn{2}{|l|}{$0.010-0.024$} & \\
\hline & \multicolumn{2}{|l|}{ Mean ratio value } & \multicolumn{2}{|l|}{ Mean ratio value } & \\
\hline & & 0.041 & & 0.017 & \\
\hline & \multicolumn{2}{|l|}{$\begin{array}{l}\text { Smoked Consumption } \\
\text { processing time }\end{array}$} & \multicolumn{2}{|c|}{$\begin{array}{l}\text { Immediate Consumption } \\
\text { Processing time }\end{array}$} & \\
\hline & \multicolumn{2}{|r|}{133.9224} & \multicolumn{2}{|r|}{55.5288} & \\
\hline & \multicolumn{2}{|l|}{ Manufacturing costs } & & & \\
\hline & \multicolumn{2}{|l|}{ Spear } & & & \\
\hline & \multicolumn{2}{|r|}{4} & & & \\
\hline & \multicolumn{2}{|l|}{ Bag Net } & & & \\
\hline & \multicolumn{2}{|r|}{11.4} & & & \\
\hline & \multicolumn{2}{|l|}{ Total } & & & \\
\hline & \multicolumn{2}{|r|}{15.4} & & & \\
\hline Summary & & & & & \\
\hline $\begin{array}{l}\text { Total hou } \\
\text { handling, }\end{array}$ & $\begin{array}{l}\text { s smoked (Capture, } \\
\text { manufacturing) }\end{array}$ & $\begin{array}{l}\text { Total hou } \\
\text { handling, }\end{array}$ & $\begin{array}{l}\text { rs fresh (Capture, } \\
\text { manufacturing) }\end{array}$ & & \\
\hline & 161.3224 & & 82.9288 & & \\
\hline Kcal per I & our smoked & Kcal per $h$ & lour fresh & & \\
\hline & 35635.86954 & & 87441.37139 & & \\
\hline
\end{tabular}


Appendix E. Chinook Salmon Return Rates Above the Falls Processing Cost per Kg

\begin{tabular}{|c|c|}
\hline Fresh & For Storage \\
\hline Max & Max \\
\hline 0.049 & 0.118 \\
\hline Min & Min \\
\hline 0.038 & 0.093 \\
\hline Hrs & \\
\hline $\max$ & $\max$ \\
\hline 289.4606498 & 697.0685036 \\
\hline $\min$ & $\min$ \\
\hline 224.4796876 & 549.3844986 \\
\hline Total hours processed & \\
\hline $\min$ & $\min$ \\
\hline 813.4796876 & 1138.384499 \\
\hline Max & $\max$ \\
\hline 886.4606498 & 1294.068504 \\
\hline
\end{tabular}

\begin{tabular}{|c|c|}
\hline $\begin{array}{l}\text { Fresh } \\
\text { Post Processing Kcal/ hr }\end{array}$ & $\begin{array}{l}\text { Dried } \\
\text { Post Processing } \\
\text { Kcal/ hr }\end{array}$ \\
\hline $\min$ & $\min$ \\
\hline 14794.04602 & 8034.314971 \\
\hline $\max$ & $\max$ \\
\hline 16121.28716 & 9133.077589 \\
\hline
\end{tabular}


Appendix F. Summary of Report References by Sub-Basin

Mid-Willamette Valley

Armitage, Charles L. and Leal H. Heupel

1993 Jory Cemetary Project: A Preliminary Archaeological Assessment.

Prepared for the Jory Family Cemetery Association. Continuum Cultural

Resource Consultants, Inc. Technical Report No. 93-1.

Baker, R. Todd, David V. Ellis, and John L. Fagan.

2003 Archaeological Test Excavations at 35MA176, Salem Oregon. Prepared for Environmental Science \& Assessment, LLC. Archaeological Investigations Northwest, Inc. report no. 1044

Baxter, Paul W. and Rick Minor 1987 US Sprint Fiber Optic Cable Project Eugene, Oregon to Seattle Wasington, Archaeological Testing of Five Sites in Oregon: 35LA88, 35LA89, 35LA149, 35LA354, 35PO03, Addendum \#3 to the Technical Report. Prepared for US Sprint. Heritage Resource Associates. Heritage Research Associates Report No. 58

Becker, Thomas H. and Bill R. Roulette 2008 Cultural Resource Investigation of the Oregon State Hospital Property, Marion County, Oregon. Prepared for Architectural Resource Group. Applied Archaeological Research Inc. Report no. 682.

Bell, James

Unlist Report of the Reconnaissance, Testing and Excavation Results of the Mahoney Ranch Site, 35MA57, Willamette Valley, Oregon. Report housed at the Oregon SHPO.

Darby, Melissa Cole

2004 Archaeological Cultural Resources Inventory and Assessment-Fairview Training Center. Lower Columbia Research \& Archaeology.

Ellis, David V.

1994 Cultural Resource Evaluation of the Proposed Fairview Industrial Park, Salem, Oregon. Archaeological Investigations Northwest, Inc. Prepared for City of Salem.

Fagan, John L., Todd R. Baker, and Judith A. Chapman

2004 Results of Testing and Evaluation Work for the Proposed Department of Public Safety Standards and Training Facility, Salem, Oregon. Prepared for 
Yost Grube Hall Architecture. Archaeological Investigations Northwest, Inc. Report No. 1249

Fagan, John L., Robert M. Burnett, David V. Ellis, Melissa Lee, Jo Reese, Billy Ray Roulette, Douglas C. Wilson, Julia J. Wilt, and John S. Witherow 1992 Northwest Pipeline System Expansion Project Cultural Resources Assessment Report: Oregon Segments. Phase 2: Testing, Site Evaluation, and Impact Assessment. Archaeological Investigations Report No. 23. Prepared for Northwest Pipeline Corporation.

Fagan, John L., Robert M. Burnett, Judith Sanders Chapman, Maureen Newman, Jo Reese, Bill R. Roulette, Douglas C. Wilson 1993 Results of a Phase 1 Cultural Resources Assessment: Northwest Pipeline Corporation's Expansion II Project, Oregon Facilities. Report prepared for EBASCO Environmental, Lyndhurst, New Jersey, and Northwest Pipeline Corporation, Salt Lake City, Utah. Archaeological Investigations Northwest Report No. 35. Portland, Oregon.

Fagan, John L., Jo Reese, Robert M. Burnett, Judith Sanders Chapman, Timothy J. Hills, Maureen Newman, Bill R. Roulette, Douglas C. Wilson, Julia J. Wilt

$1994 \quad$ Results of a Phase 2 Cultural Resources Testing and Evaluation:Northwest Pipeline Corporation's Expansion II Project, Oregon Facilities.Report prepared for EBASCO Environmental, Lyndhurst, New Jersey, and Northwest Pipeline Corporation, Salt Lake City, Utah. Archaeological Investigations Northwest Report No. 49. Portland, Oregon.

Fagan, John L., Judith S. Chapman, Maureen N. Zehendner, Kelly N. Kritzer, Jo Reese, David A. Ball, Bonnie J. Mills

Cultural Resources Survey of Level 3's Proposed Fiber Optic Line From Eugene to Portland, Oregon. Prepared for Parsons Brinckerhoff Quade \& Douglas,

Gilsen, Leland

1987 The Luckiamute Project: Test Excavations at 35 PO 57. Document on file at the Oregon State Historic Preservation Office, Salem.

McCormick, Erica D.

2008 Results of an Archaeological Survey of Part of the Slayden Property, Polk County, Oregon. Prepared for Slayden Construction Group, Inc. Applied Archaeological Research Inc. report no. 704

McCormick, Erica D. and Bill R. Roulette 
2008 Archaeological Testing of Two Sites Along the Proposed Ash Creek Trail, Independence, Oregon. Prepared for the City of Independence. Applied Archaeological Resaerch, Inc. Report No. 711.

Minor, Rick and Stephen Dow Beckham

1986 Cultural Resource Overview and Inventory of the Hayesville InterchangeBattle Creek Interchange Pacific Highway, Marion County Oregon. Heritage Research Associates.

Minor, Rick, Robert R. Musil and Linda Ferguson Sprague 1992 Archaeological Testing at Willamette Falls Locks, Clackamas County, Oregon. Prepared for Portland District U.S. Army Corps of Engineers. Heritage Resource Associates Report No. 127.

Minor, Rick and Kathryn Anne Toepel

1995 Archaeological Testing at the Mill Creek Prehistoric Site Complex, Interstate 5 and Santiam Highway, Marion County, Oregon. Prepared for Oregon Department of Transportation. Heritage Research Associates, Inc report no. 186

Musil, Robert R. 2005 Archaeological Evaluation of Archaeological Site 35MA196, Mill Creek Sanitary Sewer Project, City of Stayton, Marion County, Oregon. Prepared for Emery \& Sons. HRA Letter Report 05-32.

2006 Archaeological Evaluation of Site 35MA197 and Additional Discovery Probing along the Mill Creek Sanitary Sewer Project, City of Stayton, Marion County, Oregon. Heritage Research Associates Letter Report no. 06-24, Eugene.

O'Neill, Brian 1990 Re: Preliminary Report of Testing at Seven Archaeological Localities Within the Joseph St. Interchange - Stayton Section, North Santiam Highway (OR 22), Marion County. University of Oregon.

1992 Archaeological Evaluation of Seven Sites Along the North Santiam Highway, Marion County: Joseph Street at Stayton NCL Section. OSMA report 92-7. University of Oregon. State Museum of Anthropology.

Pettigrew, Richard M.

1980 Archaeological Investigations at Hagar's Grove, Salem, Oregon. University of Oregon Anthropological Papers. 
1980 Archaeological Investigations at the Looney Site 934-DO-13, Douglas County, Oregon. University of Oregon Anthropological Papers no, 18.

Roulette, Bill R. and Melissa L. Lehman.

Results of a Cultural Resource Survey of the North Riverfront Ball Fields Development, Independence, Oregon. Prepared for City of Independence. Applied Archaeological Research, Inc. report no. 745.

Roulette, Bill R., Julie J. Wilt, Erica McCormick, and Kendal McDonald 2007 Archaeological Investigations at a Part of the Proposed Ash Creek Trail, Independence, Oregon. Prepared for City of Independence. Applied Archaeological Resaerch, Inc. Report No. 661.

Smits, Nicholas J., R. Todd Baker, Judith A. Chapman, and John L. Fagan 2004 Results of Data Recovery Excavations at Sites 35MA183/35MA184 for the Proposed Department of Public Safety Standards and Training Facility, Salem, Oregon. Prepared for Yost Grube Hall Architecture. Archaeological Investigations Northwest, Inc. Report No 1398.

Tasa, Guy L. 2003 Re: Preliminary Report on Archaeological Excavations at Three Sites within the Santiam Highway - Battlecreek Section of the Pacific Highway (I-5), Marion County, Oregon. Prepared for the Oregon Department of Transportation. Oregon State Museum of Anthropology.

Tasa, Guy L. and Thomas J. Connolly 2000 An Archaeological Evaluation of the Hofman Road Site (35PO65), Hoffman Road Intersection, Oregon Highway 99W (Pacific Highway West), Polk County. Report Prepared for Oregon Department of Transportation.

Tasa, Guy L. and Julia A. Knowles 2005 Re: Final Report on an Archaeological Survey and Exploratory Excavations at the Butteville Drainfield and Septic Tank Project, Marion County. OSMA Report \# 2005-257. Prepared for Oregon parks and Recreation Department. Oregon State Museum of Anthropology.

Thoms, Alston V. and Denise Carlevato 1981 Cultural Resource Investigations along the Bonneville Power Administration's Proposed Chemawa-Salem Transmission Line, Polk and Marion Counties, Oregon. Bonneville Cultural Resources Group.

Wilt, Julie J. 
2007 Re: Summary of Evaluative Testing of Site AAR 661-1 Located on Part of the Proposed Ash Creek Trail, Polk County, Oregon. Prepared for City of Independence.

Wilt, Julie and Bill R. Roulette 2008 Results of an Archaeological Survey of the Proposed Ash Creek Trail from Site 35PO83 to Riverview Park, Independence, Polk County, Oregon. Applied Archaeological Research, Inc. Report No. 679. Prepared 
Yamhill

Becker, Thomas E. and Bill R. Roulette

2006 Results of an Archaeological Survey of the North Buswell Project, Grand Ronde, Oregon. Prepared for the Confederated Tribes of Grand Ronde.

Becker, Thomas E., Bill R. Roulette and Erica McCormick

2008 Archaeological Investigations at the Confederated Tribes of the Grand Ronde's Proposed Tribal Museum and Cultural Center Development Property, Grand Ronde, Polk County, Oregon. Applied Archaeological Research, Inc.

Report No. 702. Prepared for the Confederated Tribes of Grand Ronde.

O'Rourke, Leslie M. and Gretchen A. Kaehler

2004 Data Recovery and Analysis of the Werth Rock Feature (35PO74) Grand Ronde, Oregon. Prepared for the Yamhill Valley Museum of Anthropology, Grand Ronde.

Stewart, R. M.

Unlist Phase I Archaeological and Historical Resource Survey. In Final Environmental Impact Statement, Federal Correctional Institution Complex Sheridan, Oregon. Prepared for U.S. Department of Justice Federal Bureau of Prisons.

Unlist Phase 2 Archaeological Survey. Prepared for U.S. Department of Justice Federal Bureau of Prisons.

Wilt, Julie J. and Bill R. Roulette 2007 Results of an Archaeological Survey of the Grand Ronde Road Widening, Pedestrian Safety, and Utilities Upgrade Project, Polk County, Oregon. Applied Archaeological Research, Inc. Report No. 649. Prepared for Confederated Tribes of the Grand Ronde. 
N. Santiam

Beardsley, Felicia Rounds

1990 Shade Cove (35 MA 49) Archaeological Site Evaluation. Prepared for the Detroit Ranger District, Willamette National Forest.

Bell, James

1982 Report of the Testing and Excavation of the Scarred Doe Archaeological

Site. Prepared for the Detroit Ranger District, Willamette National Forest. Forest service contract\# 43-0455-2-082.

Churchill Thomas E. and Paul Christy Jenkins 1991 Archaeological Evaluation of the Short Saddle Site. Prepared for the Detroit Ranger District, Willamette National Forest.

Draper, John A., Eileen M. A. Draper, and Deborah L. Olson 1994 Helicopter Logging and Blowdowns: Phase I Testing at the Rue-Twad (18-04-295), Cara Root (18-04-299), and Brigitte's Bonanza (18-4-354) Sites, and Phase II Testing at the Caution Crossing (35LIN515) and Albright and Shiny (35LIN525) Sites, Willamette National Forest, Linn County, Oregon. Prepared for Detroit Ranger Station, Willamette National Forest.

Elserrer, Kathryn

1985 Low Blow Site (18-04-91/35 LIN 133) Determination of Eligibility, Linn County T. 10S, R. 5E, Section 35 Detroit Quadrangle.

Fagan, John L., Robert M. Burnett, David V. Ellis, Melissa Lee, Jo Reese, Billy Ray Roulette, Douglas C. Wilson, Julia J. Wilt, and John S. Witherow 1992 Northwest Pipeline System Expansion Project Cultural Resources Assessment Report: Oregon Segments. Phase 2: Testing, Site Evaluation, and Impact Assessment. Archaeological Investigations Report No. 23. Prepared for Northwest Pipeline Corporation.

Fagan, John L., Bill R. Roulette, Douglas C. Wilson, David V. Ellis, Judy S. Chapman 1996 Northwest Pipeline Corporation System Expansion Phase 1: Phase 3 Data Recovery and Site Treatment Reports for Oregon Segments. Volume V, Part 1: Willamette Valley. Prepared for Northwest Pipeline Corporation. Archaeological Investigations Northwest, Inc. Report No. 50.

Helzer, Margaret M.

2003 The North Santiam Bridges Project: Subsurface Reconnaissance and Archaeological Testing at Whitewater Creek Sites 1,2 and 3 (35LIN675, 
35MA187, 35MA188), Marion Creek Sites 1 and 2 (35LIN673, 35LIN674), Pamelia Creek Cabin (35LIN676), in Linn and Marion Counties, U.S> Highway 22 and the Suttle Lake Methodist Camp Site (35JE278), in Jefferson County, U.S. Highway 20. Prepared for the Oregon Department of Transportation. Museum of Anthropology Report 2003-6.

Henrickson, Norman D. and E. H. Winterhoff 2006 Re: Test Excavations at Site 35MA92 (Bridges 08120, 08121, and 08122, Interstate 5 over Santiam Overflows No. 2, No. 1 and No. 3 at Moile Points 241.70, 241.35, and 241.12), Marion county Oregon. University of Oregon Museum of Natural and Cultural History Research Report No. 2006011.

Jenkins, Paul Christy and Thomas E. Churchill 1984 An Archaeological Evaluation of the Fox Bug Site 35MA48. Prepared for Willamette National Forest. Report Number: R2005061804003.

1987 Archaeological Investiations of the North Park Headwaters (35 LIN 253) and the Norht Park Salvage (35 LIN 186) Sites, Sweet Home Ranger District, Willamette National Forest. Prepared for the Willamette National Forest. Coastal Magnetic Search \& Survey Report No. 22.

Kelly, Cara 2005 Cultural Resource Inventory Reort for the Humbug Campground Toilet Installation Project. Detroit Ranger District Willamette National Forest.

Regula, Thomas

1982 Breitenbush Hot Springs Resort Reconstruction Determination of Effect on Breitenbush Lower Springs Archaeological Site. Prepared for the Detroit Ranger District, Willamette National Forest.

2005 Detroit Flats (35 MA 66) Archaeological Site Testing, Detroit Ranger District Willamette National Forest, North Santiam Subbasin Western Oregon Cascade Mountains. Report Number: R2006061804001.

Silvermoon, Jon M.

1990 Preliminary Test Excavations of Two Archaeological Localities, Santiam River Bridge Project \#8123A, Pacific Highway (Interstate 5), Marion County, Oregon. Prepared for the Oregon Department of Transportation.

1990 Phase II Archaeological Test Excavation of the A.C. White Site, 35MA92, Santiam River (Southbound) Bridge Project \#8123A, Pacific Highway (Interstate 5), Marion County, Oregon. 
Spencer, Lee

1989 Archaeological Testing of the Bee Bee Site 35LIN302, A Low Density Site on the Detroit District of the Willamette National Forest. Prepared for the Willamette National Forest.

Tasa, Guy L.

1991 Archaeological Investigations at the A.C. White Site (35MA92), Marion County, Oregon. Prepared for the Oregon State Highway Division, Environmental Section. 


\section{S. Santiam}

Becker, Thomas E.

2006 Results of an Archaeological Survey Conducted as Part of the SantiamAlvey No. 1 and 2 Transmission Line Upgrade Project, Linn and Lane Counties, Oregon. Submitted to The Bonneville Power Administration.

Cole, Mandy

1987 Summary of Preliminary Testing of the Doe Mountain Archaeological Sites (Temporary Numbers 18-03-185 to 18-03-192) Willamette Industries land Exchange, T 14S, R2 E, Section 12 W.M. Sweet Home Ranger District, Willamette National Forest.

Cox Jr., James B.

1987 Determination of Eligibility for the Moose Ridge \#4 Site, Temporary Number 18-03-100, Sweet Home Ranger District, Willamette National Forest, Linn County, Oregon.

Elsesser, Kathryn

1985 Archaeological Evaluation of the Dopey Site (18-04-15), T11S, R 5E, Section 15, W.M. Detroit Ranger District, Willamette National Forest.

Flenniken, J. Jeffrey and Terry L. Ozbun 1994 Toad Archaeological Testing and Evaluation Project (35LIN306, 35LIN327, 35LIN503, 35LIN510). Report prepared for Sweet Home Ranger District, Willamette National Forest. Lithic Analysts Research Report No. 42.

Flenniken, J. Jeffrey, Terry L. Osbun, and Jeffery A. Markos 1990 Archaeological Testing and Evaluation of the Swamp Peak Way Trail One Site, 35LIN373. Research Report No. 18

1991 Archaeological Testing and Evaluation of Four Sites: 35LIN391, 35LIN392, 35LIN393, 35LIN400. Prepared for the Sweet Home Ranger District, Willamette National Forest. Lithic Analysts Research Report No. 26.

Jenkins, Paul Christy and Thomas E. Churchill 1988 Archaeological Data Recovery at the Chimney Peak One Site 35LIN312. Report prepared for the Willamette National Forest. Coastal Magnetic Search \& Survey Report No. 25.

Laybolt, A. Dawn, Sloan Craven, and Thomas E. Becker 
2006 Results of Limited Test Excavations Conducted at site 35LIN702, Linn County, Oregon. Report submitted to Bonneville Power Administration. Applied Archaeological Resaerch Report No. 556c.

Lindberg-Muir, Catherine 1983a Archaeological Test of the Soda Fork Way I Site (Temporary Number 1803-90), T. 13S, R. 5E, Section 30, W.M. Sweet Home Ranger District, Willamette National Forest. Prepared for the Willamette National Forest.

1983b Archaeological Test of the Soda Fork Way II Site (Temporary Number 18-03-88), T. 13S, R. 5E, Section 29, W.M. Sweet Home Ranger District, Willamette National Forest. Prepared for the Willamette National Forest.

1984 Archaeological Test of the Yukwah Site 35 LIN 118 T. 13S, R. 4E, Section 33, W.M. Sweet Home Ranger District, Willamette National Forest. Prepared for the Willamette National Forest.

1986 Archaeological Test and Evaluation of Three Chimney Peak Sites (Temporary Number 18-03-126, 18-03-127, 18-03-135), T. 12S, R.5E, Sections 6 and 7, W.M. Unsurveyed, Sweet Home Ranger District, Willamette National Forest.

Linderman, Carole A. 1992 Phase I Excavation Report, Doug Shank Dispersed Camp Site, 18-03360, Lane County Oregon, Sec. 33, T. 13S, R. 4E W.M. Prepared for the Sweet Home Ranger District, Willamette National Forest.

1992 Phase 1 Excavation Report, Hyatt West Three Site, 18-03-148, Linn County, Oregon, Sec. 9, T. 14S, R. 4E. W.M. Prepared for the Sweet Home Ranger District, Willamette National Forest.

Nilsson, Elena 1989 Archaeological Data Recovery Investigations at the Bear Saddle Site, 35LIN301, Willamette National Forest, Oregon. Prepared for Willamette National Forest.

O'Neill, Brian L. and Dennis L. Jenkins

2001 Archaeological Evaluation of the Sicer Drive Site (35LIN660), Linn County, Oregon. OSMA Report 2001-6.

Prouty, Guy and James B. Cox Jr. 
1987 Determination of Eligibility for the Moose Ridge \#3 Site, Temporary \# 1803-99, Sweet Home Ranger District, Willamette National Forest, Linn County, Oregon.

Southard, Michael D.

ND Archaeological Testing at the Camas Beach Site (35LIN651), Linn

County, Oregon.

1999 Additional Archaeological Testing at the Camas Beach Site (35LIN651), Linn County, Oregon.

Toepel, Kahryn Anne and Paul W. Baxter

1987 Archaeological Testing at Fern Ridge Reservoir: Sportsman's Resort and Tripass Ski Club. Prepared for the Portland District US Army Corps of Engineers. Heritage Resource Associates Report No. 53.

Wilson, Douglas C.

1998 Archaeological Test Excavations at the Work Center Site (FS\# 18-03394), Sweet Home, Oregon. Prepared for Sweet Home Ranger District, Willamette National Forest. Archaeology Consulting Report No. 5.

Winthrop, Kathryn R. and Dennis J. Gray

1985 Moose Molalla One Data Recovery Excavation, Site 35LIN139, Township 13 South, Range 4 East, Section 11 Prepared for the U.S. Forest Service, Sweet Home Ranger District, Willamette National Forest. Purchase Order No. 43-04R4-4-01300.

1988 Sheep Joe Archaeological Site Test Excavations, Temporary Site Number 180389, Willamette National Forest, Sweet Home Ranger District, T14S, R5E, Sections 3 and 4. Prepared for the Willamette National Forest. 
Upper Willamette

Baker, R. Todd

2006 Evaluation of Archaeological Site 35LA1309 and Survey of an Additional Area for the Highway 58 Bridge No. 07110 Replacement Project, Lane County, Oregon. Prepared for KPFF Consulting Engineers. Archaeological

Investigations Northwest Inc. Report No. 1752.

Baker, R. Todd, David V. Ellis, and Terry Ozbun

2004 Archaeological Test Excavations at Four Sites for the West Cascade Energy Facility, Lane County, Oregon. Archaeological Investigation Northwest, Inc. Report No. 1244. Prepared for West Cascade Energy, LLC.

Baxter, Paul and Tom Connolly

2006 Evaluation of Archaeological Site 35LIN650, US Highway 20, Reeves Parkway - UPRR (Lebanon Project, Linn County (ODOT Key no. 14640), Museum Report 2006-095. Prepared for Geo-Environmental Services Unit.

Baxter, Paul W. and Rick Minor 1987 Preliminary Archaeological Investigations at the Proposed Eugene Gwen Site, Lane County Oregon. Prepared for USR Corporation. Heritage Research Associates Report no. 54

Baxter, Paul W. and Kathryn Anne Toepel 1986 Cultural Resource Investigations at Fern Ridge Reservoir: Sportsman's Resort and Tripass Ski Club. HRA Letter Report 86-3

Bell, James W.

1984 Report of the Testing and Excavation of the Gordon Site (35PO8).

Davis, Wilbur A.

1970 Archaeology of Phase I. Little Muddy Creek, Oregon. Prepared for the National park Service.

Havercroft, Francine M.

1985 Subsistence Variability in the Willamette Valley. Prepared for USDI Fish and Wildlife Services. Oregon State University Dissertation.

Henrickson, Norman and E. H. Winterhoff

2005 Test Excavations at Site 35LIN678, 35LIN679, and 35LIN-428 (Bridges 8236 N/S over Calapooia River, Interstate 5 at Milepoint 218.8) Linn County, Oregon. UO Museum of Natural and Cultural History Research Report No. 2005-210. Prepared for Geo-Environmental Services. 
Lebow, Clayon

1986 Archaeological Testing at Site 35LIN292 within the Proposed Tangent Sewer System, Linn County, Oregon, Phase I and II. Cascade Archaeological Research Report \#5.

Lebow, Clayton G., Douglas R. Harrow, Charles M. Hodges, Andrew J. Bailey, and Jennifer J. Thatcher

1996 Archaeological Investigations along Oak Creek and the Calapooia River, Albany, Oregon.

Miller, Floyd Eugene

1975 The Benjamin Sites (35 LA 41, 42). In Archaeological Studies in the Willamette Valley, Oregon. Ed. C. Melvin Akens.

Munsil, Robert R.

2005 Archaeological Test Excavations at the Calapooia River (Driver Road) Bridge No. 12569, Linn County, Oregon. Heritage Research Associates Report No. 284. Prepared for OBEC Consulting Engineers.

Oetting, Albert C.

2005a Archaeological Evaluation of 35LA1283, Diamond Ridge Subdivision Project, Coburg, Lane County, Oregon. Heritage Research Associates Report No. 293. Prepared for Van Duyn Land Company LLC.

2005b Archaeological Evaluation of 35LA1283, Diamond Ridge Subdivision Project, Coburg, Lane County Oregon. Heritage Research Associates Report No. 293. Prepared for Van Duyn Land Company LLC.

O'Neill, Brian L.

1987 Archaeological Reconnaissance and Testing in the Noti-Veneta Section of the Florence-Eugene Highway, Lane County, Oregon. OSMA Report 87-6.

O'Neill, Brian, Thomas J. Connolly

1999 Archaeology of the Chalker Site (35LA420). In The Long Tom and Chalker Sites: A Holocene Geoarchaeological Record for the Upper Willamette Valley. Ed. O'Neill, Brian, Thomas J. Connolly, And Dorothy E. Freidel. OSMA Report 99-6.

Regan, Dennis C. and Bryn Thomas 1993 The Results of Test Excavations at 35LIN554, Linn County, Oregon. Submitted to Bonneville Power Administration. Short Report 344. 


\section{Rogers, Ann Bennett}

1996 The Office View Site, 35BE 51: An Open Air Lithic Scatter, Benton

County, Oregon. Report for the Oregon State Historic Preservation Office.

Roth, Barbara J., Sally Bird, and Chris Broyles

1999 Text Excavations at 35BE64, the Cool Guy Russ Site, and 35BE65, the Lara Gayle Site, in the McDonald Research Forest, Corvallis, Oregon.

Submitted to Oregon State University Research Forests.

Ruiz, Christopher, Guy Tasa, Dustin Kelly, and Brian O'Neill 2008 Additional Archaeological Testing of Proposed Improvements within the Thompson's Mills State Heritage Site, Linn County (Museum Report 2008-056).

Smith, Robin L. and Paul W. Baxter 1996 Investigations on the Lower Luckiamute: Archaeological Testing of 35PO15 and 35PO47. Anthropological Reports No. 1.

Southard, Michael D.

Horse Rock Shelter Test Excavation.

2000 Archaeological Test Excavations at the Cassnor \#3 Site (35LIN416), Linn County, Oregon.

Toepel, Kathryn Anne and Rick Minor 1980 Archaeological Investigations at the Flanagan Site (35LA218): The 1978 Season. 
Tualatin

Davis, Wilbur A.

1970 Scoggin Creek Arcaeology, 1969, Final Report. Prepared for the National Park Service.

Ellis, David V. 1998 Test Excavations at 35CL225, West Linn, Oregon. Prepared for West Linn, Wilsonville School District. Archaeological Investigations Northwest Report No. 230.

Ellis, David V. and John L. Fagan 1990 Archaeological Testing of the Horse Oad Site (35WN19) Washington County, Oregon. Prepared for ASB Construction Co., Inc. Archaeological Investigations Northwest Report No. 7

Ellis, David V. and Eric E. Forgeng 1998 Dawson Creek Sanitary Sewer Line, Hillsboro: Evaluation of Sites 35WN22 and 35WN45, and Survey of Proposed Staging Areas and Ancillary Areas. Prepared for David Evans and Associates, Inc. Archaeological Investigations Northwest, Inc. Report No. 141.

Musil, Robert R.

1995 An Archaeologial Assessment of 35WN17 for the Tualatin Development Project, Tualatin, Oregon. Prepared for Anderson Construction Company, Inc. Heritage Research Associates Report No. 183.

Simmons, Alexy

1985 Archaeological Investigation of 35WN20 (SE1/4 of SE 1/4 of Section 26, T1N, R2W, Hillsboro Quadrangle, Washington County Oregon); for Proposed Road Corridor Alternative No 1, Cornell Road, Washington County, Oregon.

Wilt, Julia J, and David V. Ellis 1996 Test Excavations at 35CL223, Brown's Ferry Park, Tualatin, Oregon. Prepared for Kurahashi and Associates and City of Tualatin Parks and Recreation Department. Archaeological Investigations Northwest Report No. 110. 
Coast Fork

Baxter, Paul W. and Mark A. Swift

1983 The Hobby Field Site, An Archaeological Investigation of Site 35LA133 at the Creswell Airport. Prepared for the Federal Aviation Administration.

Bland, Richard L.

1989 Further Investigations at Shortridge Park (35LA265), Lane County, Oregon. Prepared for the U.S. Army Corps of Engineers, Portland District. Heritage Research Associates Report No. 84.

Bland, Richard L. and Kathryn A. Toepel

1988 Cultural Resource Investigations at Baker Bay, Dorena Reservoir. HRA Letter Report 88-3.

Boersema, Jana and Robert R. Munsil 1998 Archaeological Assessment of Proposed View Heights Subdivision, Cottage Grove, Lane County, Oregon. HRA Letter Report 98-2.

Cabebe, Teresa E.

2004 Test Excavations at Site 35LA1289 (Bridges 07757A and 07757BGetting's Creek, Interstate 5 at MP 178.4), Lane County, Oregon. UO Museum of Natural and Cultural History, Research Report No. 2005-14.

2005 Test Excavations at Sites 35LA1187, 35LA1228, and 35LA1231 (Bridges 05285A, 05286, and 05287b, Coast Fork Willamette River Relief Opening, Coast Fork Willamette River, and Willamette River Relief Bridges, OR 58, MP1.96, 2.46, and 2.71) Lane County Oregon. Museum of Natural and Cultural History, Research Report No. 2005-19.

Cole, David L.

1978 Archaeological Investigations at Shortridge Park Cottage Grove Reservoir, Lane County, Oregon. Prepared for the U.S. Army Engineer District, Portland.

Gauthier, Tara

2007 Data Recovery Excavation for Two Proposed Vault Toilets at the Packard Creek Campground Site 35LA475, Lane County, Oregon. Prepared for Willamette National Forest.

Oetting, Albert C.

1991 Summary of Test Excavations and Recommendations for the Table Site (35LA927). HRA Letter Report 91-11. 
Silvermoon, Jon M.

1991 Phase II Archaeological Test Excavations of Four Sites and Two

Localities, Goshen-Immigrant Road Section, Willamette Highway (OR 58), Lane County, Oregon. Prepared for the Oregon Department of Transportation. IRI Report No PNW91-5.

Stevens, Rebecca A. and Jerry R. Galm

1991 Results of Phase 2 Investigations of the Bonneville Power

Administration's Latham Tap Project, Lane County, Oregon. Archaeological and Historical Services, Short Report 261.

Tasa, Guy L. and Thomas J. Connolly

2000 An Archaeological Evaluation of the Papenfus Site (35LA1228), Goshen

- Pheasant Lane Section of the Willamette Highway (OR 58), Lane County.

Museum of Anthropology Report 2000-6 


\section{McKenzie}

Bell, James W.

1982 Report of the Testing and Excavation of the Norwegian Creek Site (35LA434). Prepared for the McKenzie Ranger District.

Bergland, Eric O.

1989a Phase I Test Evaluation, 35-LA-325, Blue River Ranger District, Willamette National Forest.

1989b Phase I Test Evaluation, 35-LA-846, Blue River Ranger District, Willamette National Forest.

1990a Phase I Test Evaluation, Pat Saddle Site (01-77), Blue River Ranger District, Willamette National Forest.

1990b Phase I Test Evaluation Near 35-LA-822, Blue River Ranger District, Willamette National Forest.

1990c Phase I Test Evaluation, Fritz Site (0709, 35LIN91) McKenzie Ranger District, Willamette National Forest.

1993 Phase I Test Evaluation, HR\# 07-360 (The Mill 4 Site), McKenzie Ranger District, Willamette National Forest.

1994 Phase I Testing and Lithic Analysis of Collections from the Lookout Boatramp Site (35-LA-1020).

Cole, Mandy

1986 Archaeological Test and Evaluation of the Dane Saddle Site (Temporary Number 18-03-182), T.13S, R6E, Section 36, W.M. Sweet Home Ranger District, Willamette National Forest.

Cox Jr., James B.

1986 McKenzie KV Site, Temporary Number 18-07-69, Determination of Elligibility, McKenzie Ranger District, Willamette National Forest, Lane County, Oregon, T16S, R7E, Section 3, WM, Three Sisters Quadrangle.

Flenniken, J. Jeffrey, Terry L. Ozbun, and A. Catherine Fulkerson 1989 Archaeological Test Excavations, at the Warehouse Site, 35LA822, Blue River Ranger District, Willamette National Forest, Oregon.

Jenkins, Paul Christy 
1986 Archaeological Evaluation of the Cupola Site, McKenzie Ranger District, Willamette National Forest.

Oetting, Albert C.

1994 Archaeological Testing and Evaluation at Sites in Blue River and Cougar Reservoirs, Lane County, Oregon. Prepared for the United States Army Corps of Engineers. Heritage Research Association Report No. 172.

1995 Cultural Resources Reconnaissance and Probing to Relocate Site 35LA657, Springfield, Lane County Oregon. Prepared for MountainGate Properties, Inc. HRA Letter Report 95-33.

2002 Summary of Archaeological Data Recovery Investigations at 35LA1261, MountainGate Residential Development Phase 1, Lane County, Oregon. Prepared for Land Planning Consultants. HRA Letter Report 02-23.

2004 Summary of Evaluation Test Excavations at 35LA1276, MountainGate Residential Development, Springfield, Lane County, Oregon. Prepared for Land Planning Consultants. HRA Letter Report 04-03.

2006 Archaeological Investigations for the Eugene Water and Electric Board Carmen-Smith Hydroelectric Project, Lane and Linn Counties, Oregon.

Prepared for the Eugene Water and Electric Board and Stillwater Sciences. Heritage Research Associates Report No. 290

South, Barry and Eric O. Bergland 1997 Phase I Test Evaluation 35-LA-987, HR\# 07-283 (The Mega Site), McKenzie Ranger District, Willamette National Forest.

Southard, Michael D.

1986 An Archaeological Evaluation of the Mill Creek No. 6 Site (35LA365), Lane County Oregon.

1987 An Archaeological Evaluation of the Hatchery Tributary Site (35LA469), Lane County, Oregon.

1989 An Archaeological Evaluation of the Crack Shot Site (35LA848), Lane County, Oregon.

1990 An Archaeological Evaluation of the Vacuum Site (35LA875), Lane County, Oregon. 
1991 An Archaeological Evaluation of the Scant Site (35LA945), Lane County, Oregon.

1996 The Rum Site (35LA958): A Cache of Large Obsidian Flakes from the Cartwright Creek Drainage, Lane County, Oregon.

1999 An Archaeological Analysis of the Log Site (35LA1023), Lane County, Oregon.

2000 Archaeological Test Excavations and Surface Collection at the Marksman Site (35LA1098), Lane County, Oregon.

Toepel, Kahtryn Anne and Richard L. Bland

1991 Archaeological Investigations at the Eweb Walterville Storage Pond (35LA951), Lane County, Oregon. Prepared for Eugene Water and Electric Board. Heritage Resaerch Associates Report No. 103.

Wintrhop, Kathryn and Dennis Gray 1989 Testing and Evaluation of Two Sites on the Blue River Ranger District: 35LA325 and 35LA857, Lane County, Oregon. Prepared for the Blue River Ranger District, Willamette National Forest. 
Middle Fork

Baxter, Paul W.

1982 Excavations at Rigdon's Horse Pasture Cave. Prepared for the United States Forest Service, Willamette National Forest, Eugene, Oregon.

Churchill, Thomas E.

1989 Archaeological Investigations at Olsen 1 (35LA190), Olsen 2 (35LA191) and Deadhorse (35LA656) Rockshelters, Lane County, Oregon. Report prepared for the Willamette National Forest. Coastal Magnetic Search and Survey Report No. 40.

Churchill, Thomas E. and Paul Christy Jenkins

1989 Archaeological Investigations of Pepper Rockshelter (35LA801) and Katz Rockshelter (35LA802). Report prepared for the Oakridge and Lowell Ranger District of the Willamette National Forest.

Cole, David L.

1988 Archaeology of the Fall Creek Dam Reservoir Final Report.

Cox Jr. , James B.

1985 Colt '85 Site, Temporary Number 18-05-139, Determination of Eligibility, Rigdon Ranger District, Lane County, Oregon, T24S, R3E, Section 12, Oakridge Quadrangle.

1990 Phase I Excavation Report South Cupit Archaeological Site, 18-08-185, Lane County Oregon, Waldo Lake and Mt. David Douglas Quads.

Flenniken, J. Jeffrey, Terry L. Ozbun, and A. Catherine Fulkerson 1989 Archaeological Test Excavations at Five Sites (35LA320, 35LA444, 35LA814, 35LA633, 35LA632) On the Lowell and Oakridge Ranger Districts, Willamette National Forest, Oregon.

Flenniken, J. Jeffrey, Terry L Ozbun and Jeffrey A. Markos 1990 Archaeological Testing and Evaluation of the Gate Creek \#1 Site, 35LA295. Lithic Analysts Resaerch Report No. 17.

Heid, James

1982 McFarland Site (35LA564) Evaluation.

1983a Salix Site (18-05-118) Determination of Eligibility, Lane County, T22S, R3E, Section 35, Oakridge Quadrangle. 
1983b Cultural Resource Report: Web Addendum.

1983c Salix Site Preliminary Report.

1984 Dingo Boots Site -35LA584 Determination of Eligibility.

1986 Bills Creek Site -35LA519 Determination of Eligibility.

1987 Packard Creek Site - 35LA475 Determination fo Eligibility to the National Register of Historic Places, Lane County, T22, R3E Sections 10 and 11, Oakridge Quadrangle.

Oetting, Albert C.

1993 Archaeological Test Excavations at Scheid Rockshelter (35LA1026), Lane County, Oregon. Heritage Research Associates Report No. 145

Silvermoon, Jon M.

1991 Phase II Archaeological Test Excavations of Four Sites and Two Localities, Goshen-Immigrant Road Section, Willamette Highway (OR 58), Lane County, Oregon. Prepared for the Oregon Department of Transportation. IRI Report No PNW91-5.

Southard, Michael D.

1989 An Archaeological Evaluation of the Manson Site (35LA818), Lane County, Oregon.

Steffen, Anastasia and Carol Winkler

1998 Phase 1 Excavations at Two Small Sites in the Christy Basin Timber Project, Oakridge Ranger District, Willamette National Forest, USDA Forest Service.

Winkler, Carol 1988 Test Excavations at the Diamond Lil Site (35LA807), A Determination of Eligibility to the National Register of Historical Places.

1992 Test Excavations and Evaluation of the Winberry Saddle Site (35LA995) Lowell Ranger District, Willamette National Forest, Lane County, T18S, R2E, Section 28, Hardesty Mountain Quadrangle.

2005 Test Excavations at the Harrington Site (35LA285).

Wilt, Julia J., Bull R. Roulette, and Charles M. Hodges 
2001 Results of Evaluative Testing of a Section of the Natron Site, 35LA1235, Lane County, Oregon. Prepared for ATC Associates Inc. 
Molalla-Pudding

Fagan, John L., Robert M. Burnett, David V. Ellis, Melissa Lee, Jo Reese, Billy Ray Roulette, Douglas C. Wilson, Julia J. Wilt, and John S. Witherow 1992 Northwest Pipeline System Expansion Project Cultural Resources Assessment Report: Oregon Segments. Phase 2: Testing, Site Evaluation, and Impact Assessment. Archaeological Investigations Report No. 23. Prepared for Northwest Pipeline Corporation.

Keeler, Robert W.

1991 Archaeological Test Excavations at the Ruef Site, Marion County, Oregon.

Roulette, Bill R. and Jo Reese

1995 Report of Investigations of Archaeological Site 35CL200. Prepared for Roger Sprague, Canby Excavating. Archaeological Investigations Northwest, Inc. Letter Report No. 106. 